\title{
Improvements in Clinical Durability From Functional Biomimetic Metallic Dental Implants
}

\author{
Saad M. Al-Zubaidi', Ahmed A. Madfa ${ }^{1 *}$, Abdulbaset A. Mufadhal', \\ Mohammed A. Aldawla ${ }^{2}$, Osan S. Hameed ${ }^{3}$ and Xiao-Guang Yue ${ }^{4,5}$ \\ ${ }^{1}$ Department of Restorative Dental Science, College of Dentistry, University of Hail, Ha'il, Saudi Arabia, ${ }^{2}$ Department \\ of Conservative Dentistry and Endodontics, Faculty of Dentistry, Sana'a University, Sana'a, Yemen, ${ }^{3}$ Department \\ of Prosthodontics, Faculty of Dentistry, University of Aden, Aden, Yemen, ${ }^{4}$ Rattanakosin International College of Creative \\ Entrepreneurship, Rajamangala University of Technology Rattanakosin, Phutthamonthon, Thailand, ${ }^{5}$ Department \\ of Computer Science and Engineering, School of Sciences, European University Cyprus, Nicosia, Cyprus
}

\section{OPEN ACCESS}

Edited by: Francesco Baino,

Politecnico di Torino, Italy

Reviewed by:

Andrea Cochis,

University of Eastern Piedmont, Italy Seiji Yamaguchi,

Chubu University, Japan

${ }^{*}$ Correspondence:

Ahmed A. Madfa ahmed_um_2011@yahoo.com

Specialty section

This article was submitted to Biomaterials,

a section of the journal

Frontiers in Materials

Received: 15 January 2020 Accepted: 06 April 2020 Published: 22 May 2020

Citation:

Al-Zubaidi SM, Madfa AA,

Mufadhal AA, Aldawla MA, Hameed OS and Yue X-G (2020) Improvements in Clinical Durability From Functional Biomimetic Metallic Dental Implants. Front. Mater. 7:106.

doi: 10.3389/fmats.2020.00106
The current aim in dentistry is to return the patient to normal function in terms of esthetics and speech as well as health, regardless of injury, disease, or atrophy of the stomatognathic system. Dental implant, involving the emplacement of a fixed permanent artificial root to support prosthetic dental crowns, offers the obvious treatment choice for partial and complete edentulism. Even though the rates of survival are high, dental implant failures in long-term situations still occur. This will cause the removal of implants and additional health and financial burdens. These failures are attributable to mechanical instability, poor implant integration, necrosis, inflammation, and infections and are associated with lengthy patient care, loss of function, and pain. Therefore, the objective of the current publication is to detail the main types of implants along with the current and developing approaches and technologies for surface and bulk alteration that are used to increase biological and mechanical performance under function. Notable research is highlighted regarding the present development of dental implants with biologically active surfaces and their influence on osseointegration. In addition, dental implants based on the functionally graded concept inspired by human bone are reviewed.

Keywords: dental implant, surface modification, biomimetic process, osseointegration, bone regeneration, functionally graded materials

\section{INTRODUCTION}

Patients experiencing tooth loss due to age, injury, or disease often suffer not only from functional constraints but also from the accompanying psychological and social consequences. The replacement of missing teeth is frequently accomplished by inserting single-tooth implants or implant-supported prostheses. Dental implant is considered the best treatment decision for the

Abbreviations: Ti, titanium; $\mathrm{TiO}_{2}$, titanium oxide; $\mathrm{BIC}$, bone-implant contact; $\mathrm{HA}$, hydroxyapatite; ECM, extracellular matrix; BMP, bone morphogenetic protein; rhBMP, recombinant human bone morphogenetic protein; PRGF, plasma-rich growth factor; rhbFGF, recombinant human basic fibroblast growth factor; rhIGF-1, recombinant human insulin-like growth factor-1; FGFFN, fibroblast growth factor-fibronectin; CP, calcium phosphate; PLGA, poly lactide-co-glycolide; bFGF, basic fibroblast growth factor; rhbFGF, recombinant human basic fibroblast growth factor; rhVEGF, recombinant human vascular endothelial growth factor; rhVEGFI65, recombinant human vascular endothelial growth factor I65; FGMs, functionally graded materials; FG, functionally graded; SLA, sandblasted and acid-etched; SBF, simulated body fluids; SLM, selective laser melting; SLS, selective laser sintering; EBM, electron beam melting. 
replacement of missing teeth for restoring patients' appearance, speech, and health (Esposito et al., 1999; Nag and Banerjee, 2012).

A dental implant is entirely installed into the jaw to support the dental prosthesis (Cheng et al., 2014). It is positioned in the jaw in such a way that it extends from the inside to the outside of the bone. Inside of the jaw, bone sympathy and stress relaxation are important, and, outside of the bone, in the oral cavity, adequate strength is necessary (Hedia H., 2005). However, the biomechanical performances of bone structures and dental implants are affected by many factors that interact with one another (Zarone et al., 2005, 2006). In the oral environment, many factors influence the long-standing success of prosthesis implantation. Some of these factors are reliant on the parameters such as load intensity and direction, occlusion, wear, quality of supporting tissues, temperature, and moisture, while others are not manageable, like fatigue, structural integrity, and time. Moreover, bone and materials that are used for fabricating implants are influenced by inherent physical characteristics that are accountable for their mechanical behaviors throughout their functioning over time (Van Noort, 2014). The chemical as well as the physical properties of implant materials, such as the surface composition of the implant, its microstructure, and its characteristics, are recognized factors that affect the clinical durability and outcome of dental implant (Smith, 1993).

The environmental circumstances in the oral cavity lead to an urgent need to develop newer and better implant materials and designs. Fundamentally, the implanted material should have much more reliable biocompatibility, no corrosion in body fluid, fracture and wear resistance, mechanical strength, low density, low elastic modulus, and high fatigue resistance (Smith, 1993; Okazaki et al., 1996; Sykaras et al., 2000).

Conventionally, dental implants are often fabricated from biomedical-graded materials, including titanium (Ti) and its alloys and/or ceramic (Osman and Swain, 2015). Among previously used materials, $\mathrm{Ti}$ and its alloys were selected for constructing most implants owing to their inertness, biocompatibility, and notable mechanical properties (Özcan and Hämmerle, 2012). As bone has a heterogeneous structure, insertion of homogeneous materials causes high mechanical divergence between the surrounding bone structure and implants (Özcan and Hämmerle, 2012), thereby increasing the vulnerability to loss of the dental implants during exposure to mechanical stresses (Schiefer et al., 2009; Merdji et al., 2012). In addition, the stiffness of $\mathrm{Ti}(110 \mathrm{GPa})$ is higher than that of human cortical cancellous bone (17-20 GPa and $4 \mathrm{GPa}$, respectively) (Hedia H., 2005; Krishna et al., 2007). Additionally, the variance in the thermo-physical properties of these materials might produce thermal stresses at the interface while drinking cold and hot fluids. The mechanical load applied during mastication subsequently superimposes these undesirable stresses that work at the interface between bone and implants. In addition, the fatigue type of failure and the jeopardizing of interface integrity can result from the cyclic nature of thermal loads (Hedia H., 2005; Yang and Xiang, 2007; Mehrali et al., 2013). Furthermore, and since bone is a self-motivated vital tissue that goes through continuous alterations by bone-forming as well as bone-eating cells in reaction to applied external signals, this results in decreased mechanical loading of bone, which leads to resorption of the bone, relaxation of the implant, and, finally, failure of dental implants (Hedia H., 2005). Moreover, dental implant underoverloading generates large stresses in local sections of bone, which may encourage the resorption of the bone (Isidor, 2006). An additional concern is the shape of the implant, which has been shown to be a critical factor at the bone-implant interface and can stimulate osseointegration. Inside the bone, the implant material is required to have osseoconductivity so that the new bone can be formed quickly and attached directly to it (Raghavendra et al., 2005). Previously, several efforts have been made to develop the mechanical and biological properties of many materials to make them wellmatched with the tissue of the bone. Most of these trails improve certain substantial interaction structures at the interface of bone tissue and implant surface. Current developments in bone tissue engineering scaffolds and dental implant designs have all contributed to creating novel porous Ti surfaces, and these arenas use and take advantage of each other's technologies. Therefore, this review paper presents a brief history of dental implants and new approaches to their production to improve their performance under function. Notable research is highlighted regarding (i) conventional surface modification techniques, (ii) biomimetic surface modification to enhance osseointegration, (iii) antibacterially coated implants, and (iv) dental implants based on the functionally graded concept.

\section{CONVENTIONAL SURFACE MODIFICATION TECHNIQUES}

Osseointegration is defined as "direct contact between living bone and implant. It is also histologically defined as the direct anchorage of an implant by the formation of bony tissue around the implant without the growth of fibrous tissue at the bone-implant interface". Osseointegration is the chief requirement for the long-term clinical success of the implantation process, in which functional joining between the implant surface and the bone tissue should be achieved (Javed et al., 2013; Parithimarkalaignan and Padmanabhan, 2013; von Wilmowsky et al., 2014). The osseointegration rate, quality of the bone, and bone in contact with the implant all affect the long-term success of oral implant rehabilitation (Scarano et al., 2017b). Therefore, many attempts had made to improve osseointegration, such as improvement of surgical technique, a longer healing period, and alteration of the implant surface; among them, surface alteration has been evaluated by many researchers (Yin et al., 2012). On the whole, investigation trails on metallic biomaterials have been focused on the development of superficial modifications that improve their biological and mechanical properties (Del Fabbro et al., 2017).

Many studies found that the morphology, structure, and implant surface wettability are major factors in osseointegration (Gittens et al., 2014; Rupp et al., 2014; Li et al., 2015; Hotchkiss et al., 2016; Ozdemir et al., 2016; Sartoretto et al., 2017). Ti and its alloys are broadly applied biomaterials in the production of dental implants used in maxillofacial surgery 
and in orthopedics, but $\mathrm{Ti}$ and its alloys do not directly create connections with the living bone (Oldani and Dominguez, 2012; Khan et al., 2014; Sidambe, 2014). Surface alterations, therefore, are the utmost essential approaches applied for the improvement of osseointegration (Goel et al., 2014; Chia and Wu, 2015; Mandracci et al., 2016). Surface modification of dental implants is considered an ideal strategy to obtain rapid secondary stability, improving the bone-to-implant interaction, and reducing the time required for the replacement of missing teeth (Smeets et al., 2016). The significance of the alteration of the implant surface is to maintain the important physical properties of the implant while altering only the outer surface layer to enhance the circumstances for rapid osseointegration, which is crucial to the long-term clinical success of an implant (Ellingsen et al., 2006; Puleo and Thomas, 2006; Le Guehennec et al., 2007). However, Salerno et al. (2015) evaluated implant topography before and after implantation in bovine bone using atomic force microscopy or $3 \mathrm{D}$ profilometry. They reported that no major changes happened in surface topography on implantation for most implants.

In recent years, various techniques and methodologies have been used for altering the topographical or chemical properties of traditional implant surfaces to enhance the bonding of the implant material with bone cells (Wirth et al., 2017). The alterations in the surfaces of a Ti implant permit it to stimulate the tissue of the bone, minimizing the period for osseointegration, and achieving superior transmission of occlusal mechanical loads from the implant to the bone (Al-Nawas and Wagner, 2017). Attempts to increase the osseointegration are normally approached by making surfaces rough, which in turn increases the surface area obtainable for binding the bone to the implant and enhances firmness as well as stability (Mello et al., 2016; Prasad et al., 2017). However, the biological reactions of the adjacent tissues to implant surfaces are mostly controlled by their chemical and/or morphological surface characteristics (Kasemo, 2002; Chaturvedi, 2009; Wennerberg and Albrektsson, 2010).

\section{Physicochemical Methods}

Many methods have been used to roughen $\mathrm{Ti}$ implant surfaces. These methods can be categorized by addition and subtraction into chemical, physical, and mechanical approaches. The methods include electrochemical deposition, laser ablation, acid or dual-acid etching, sandblasting with $\mathrm{TiO}_{2}, \mathrm{Al}_{2} \mathrm{O}_{3}$, or hydroxyapatite (HA), combinations of such treatments, or coating with organic biomaterials. Many biomaterials have been applied for the modification of implant surfaces such as CaP, HA, or micro/nano-coating. All of these treatments of the implant surface modify the charge, energy, and composition of the current surface, which make possible for the implant surface improved growth and cell proliferation, enhanced wettability, and improved osseointegration (Mangano et al., 2017, 2018; Scarano et al., 2018; Sinjari et al., 2018). Baier and Meyer (1988) reported that surface energy plays an essential role in protein adsorption, cell attachment, and spreading. Likewise, Meyle (1999) stated that the surface charge affects both the cellular or molecular direction and cellular metabolic activity. Several reports have shown how the microstructure increases removal torque and increases angiogenesis (Scarano et al., 2014). Moreover, surface nanoroughness is regarded as having an influence on the biological reaction to the implant (Mendonça et al., 2008; Ehrenfest et al., 2010; Durmus and Webster, 2012; Rani et al., 2012; Webster and Yao, 2016). Surface treatment techniques, with some current commercial examples, are shown in Table 1.

\section{Modification of Implant Surface Roughness at the Macroscale Level}

During the early stage of osseointegration as well as in long-term bone remodeling, the topography of the surface of implants is essential for hold and for differentiation of osteoblasts (Bruschi et al., 2015; Smeets et al., 2016). The first-generation implant surface design was a machined implant surface with a turned surface implant (Barfeie et al., 2015; Smeets et al., 2016). These earliest attempts introduced surface macro-irregularities such as grooves, pores, steps, threads, or other macroscopic irregularities. Coelho et al. (2015) stated that a suitable microgeometry, together with appropriate drill-hole preparation for implant, is the essential source of a successful clinical outcome for implantation. However, these authors found that the stability of the implant drops in the first weeks of bone healing as a result of density necrosis of adjacent bone and subsequent remodeling of bone. The high demand for initial stability and optimal interfacial bone remodeling led to a continuous search for further improvements in surface quality.

\section{Modification of Implant Surface Roughness at the Microscale Level}

In the beginning, dental implants had mainly machined surfaces (Buser et al., 2012), meaning that they were manufactured through milling, turning, or polishing (Esposito et al., 2014). Faults along these surfaces enable osteogenic cells to attach and to deposit bone, thereby creating a bone-to-implant contact (BIC). The time for healing of those implants is about 36 months, dependent on the quality of the bone as well as the anatomical location (Abraham, 2014). Therefore, 1-100 $\mu \mathrm{m}$ microscopic surface irregularities have been added to the $\mathrm{Ti}$ implant, introduced via various industrial methods including machining, sandblasting, grit-blasting, anodization, acid-etching, and different coating techniques (Dohan Ehrenfest et al., 2010). Microscopic imperfections in the surface appear to deliver an ideal degree of roughness to encourage osseointegration. Grooves, pits, and protrusions characterize the microtopography and set the stage for biological reactions at the interface between the bone and the implant surface (Albrektsson and Wennerberg, 2004). Many studies have revealed that increased micro-scale roughness of the surface clearly influences bone response to the implant due to the larger exposed surface area, which improves biomechanical joining between bone and implant compared to smooth a surface (Li et al., 2002; Rønold et al., 2003; Shalabi et al., 2006; Coelho et al., 2009; Wennerberg and Albrektsson, 2009, 2010; Ehrenfest et al., 2010). According to Shibata and Tanimoto (2015), alterations in the topography of the surface change the metabolism, growth, and migration in addition to the cytokine and growth factor creation of osteogenic cells. Modification 
TABLE 1 | Surface treatment techniques with some current commercial examples.

\begin{tabular}{|c|c|c|c|}
\hline Treatment level & Surface treatment technology & Example & Manufacturer \\
\hline \multirow[t]{7}{*}{ Microscale level } & Sandblasting & Kontact & Biotech Dental \\
\hline & Chemical etching & Kontact S & Biotech Dental \\
\hline & Grit-blasting and acid etching & $\begin{array}{l}\text { SLA surface } \\
\text { (e.g., Roxolid implant) }\end{array}$ & Straumann Holding AG, Basel, Switzerland \\
\hline & & Camlog Promote surface & Camlog, Basel, Switzerland \\
\hline & & $\begin{array}{l}\text { Semados } \\
\text { (S, SC/SCX, RS/RSX, and RI lines) }\end{array}$ & $\mathrm{BEGO}$ \\
\hline & & Integra-Ti & $\mathrm{BICON}$ \\
\hline & Grit-blasting, acid-Etching, and neutralization & $\begin{array}{l}\text { FRIADENT plus surface (ANKYLOS, } \\
\text { XiVE, and FRIALIT implant systems) }\end{array}$ & DENTSPLY Implants, Mannheim, Germany \\
\hline \multirow[t]{4}{*}{ Nanoscale level } & Sandblasting, etching and +CP coatings with ++DCD & $\begin{array}{l}\text { Osseotite surface } \\
\text { (NanoTite }{ }^{T M} / 3 i \text { T3 implants) }\end{array}$ & $\begin{array}{l}\text { BIOMET 3i, Palm Beach Gardens, FL, } \\
\text { United States }\end{array}$ \\
\hline & Laser ablation & Laser-Lok implant & BioHorizons, Birmingham, AL, United States \\
\hline & Anodization & TiUnite & $\begin{array}{l}\text { Nobel Biocare Holding AG, Zurich, } \\
\text { Switzerland }\end{array}$ \\
\hline & $\begin{array}{l}\mathrm{TiO}_{2} \text { blasting and acid-etching with fluoride-modified } \\
\text { nanostructure coating }\end{array}$ & OsseoSpeed $^{\mathrm{TM}}$ & DENTSPLY Implants, Mannheim, Germany \\
\hline \multirow[t]{3}{*}{ Coating } & Titanium plasma spraying & Kohno HRPS & Sweden \& Martina, Due Carrare, Italy \\
\hline & $\begin{array}{l}\text { Blasting and etching with a final immersion in a } \mathrm{NaCl} \\
\text { physiological solution (hydrophilic implants) }\end{array}$ & SLActive & Straumann Holding AG, Basel, Switzerland \\
\hline & Sandblasting, etching and $+\mathrm{CP}$ coatings with \pm IBAD & Integra-CP & $\mathrm{BICON}$ \\
\hline
\end{tabular}

procedures for implant surfaces at the microscale level are recognized and have been clinical routine for many years.

Some implant producers have concentrated on the $\mathrm{Ti}$ implant surface, forming a film about $100 \mathrm{~nm}$ with increased micro-porosity (30-50 $\mu \mathrm{m}$ deep) through Ti plasma spraying. The resulting coating has a roughness about $7 \mu \mathrm{m}$, which increases the surface area of the dental implant. Some authors found that this micro-porosity through $\mathrm{Ti}$ plasma spraying improved the tensile strength at the bone-implant interface (Buser et al., 1991; Palmer et al., 2002). However, Urban et al. (2000) reported particles of $\mathrm{Ti}$ in the bone neighboring implants. The same authors also reported finding wear particles from implants in small aggregates of macrophages in the spleen and liver and in the lymph nodes (Urban et al., 2000). Metal ions could possibly be released from implants through dissolution, wear, and fretting and could be a source of concern because of their carcinogenic effects either locally or systemically (Browne and Gregson, 2000; Martini et al., 2003). Currently, there is evidence of clinical benefits of implanting reasonably rough-surfaced implants compared to utilizing rough plasma-sprayed implant surfaces (Xie et al., 2012).

An alternative method for abrading the surface of a $\mathrm{Ti}$ implant consists of blasting (also called sandblasting or gritblasting) the implants with ceramic particles. Titanium oxide $\left(\mathrm{TiO}_{2}\right)$, alumina, and calcium phosphate $(\mathrm{CP})$ particles are applied for this purpose (Kim et al., 2012; Shrestha, 2014). In grit blasting, high-velocity particles of various diameters (150-350 $\mu \mathrm{m})$ are shot at the implant surface to achieve different degrees of roughness. The abrasive atoms are impacted against the material at high pressure. The resulting highly roughened implants have been shown to benefit mechanical anchorage and primary joining to bone. Clinical studies reported higher survival rates due to higher levels of marginal bone for blasted implants than for machined implants (Gotfredsen and Karlsson, 2001). However, the effect of the remnant blasting particles on the implant surface after cleaning remains controversial, because alumina is insoluble in acid and is therefore difficult to eliminate from the Ti surface. A number of authors have shown accelerated bone formation, while others have reported hampered osseointegration, which may be explained by competition with calcium ions (Cochran et al., 1996). This is due to these particles sometimes being freed into the adjacent tissues and restricting the osseointegration process. Furthermore, this chemical heterogeneity of the implant surface may reduce the exceptional corrosion resistance of $\mathrm{Ti}$ in physiological environments (Aparicio et al., 2003; van Drunen et al., 2011). Therefore, for materials blasting, the particles should be biocompatible and chemically stable and not obstruct the osseointegration process of the Ti implants.

Some authors used $\mathrm{TiO}_{2}$ for blasting $\mathrm{Ti}$ implants. Ivanoff et al. (2001) blasted micro-implants with $\mathrm{TiO}_{2}$ on and found significant improvement in BIC compared to machined surface implants (Ivanoff et al., 2001). Additional reports established that Ti-blasting of surfaces enhanced BIC (Gotfredsen et al., 1995; Rasmusson et al., 2001). Likewise, some clinical studies achieved high success rates up to 10 years after implantation for Ti-blasted implants (Gotfredsen and Karlsson, 2001; Rasmusson et al., 2005). Other relative clinical studies also noted higher levels of marginal bone and higher survival rates for implants blasted with $\mathrm{TiO}_{2}$ than for turned implants (Astrand et al., 1999; van Steenberghe et al., 2000). Abron et al. (2001) observed that increasing the surface roughness of the implants led to 
a rise in torque force while maintaining equivalent values in bone apposition.

Calcium phosphates are used as other possible blasting materials for roughening $\mathrm{Ti}$ implants due to their osteoconductive, biocompatible, and resorbable properties. Calcium phosphates can be resorbed, resulting in a clean, textured, pure Ti implant surface. Some authors have established that this achieves a higher BIC than with machined surfaces (Novaes et al., 2002; Piattelli et al., 2002) and that the BIC was comparable to that noticed with other methods such as blasting surfaces when osseointegration is accomplished (Mueller et al., 2003).

Another manner of roughening Ti implants is etching the implant surfaces with strong acids, for instance, $\mathrm{HCl}, \mathrm{HNO}_{3}$, $\mathrm{H}_{2} \mathrm{SO}_{4}$, and HF. Acid etching creates micro-pits on Ti surfaces with sizes ranging from 0.5 to $2 \mu \mathrm{m}$ in diameter (Massaro et al., 2002; Zinger et al., 2004). This method considerably accelerated osseointegration by enhancing the attachment of fibrin and osteoblasts (Wong et al., 1995). Cervino et al. (2019) found that the time necessary to obtain osseointegration and secondary stability on the part of implants is shortened through this surface treatment before implantation. Therefore, the treated surfaces guarantee enhanced cellular adhesion.

A form of macroroughness termed the Sandblasted, Large grit, Acid-etched (SLA) surface is fabricated by Straumann Holding AG, Basel, Switzerland (Figure 1). Such a surface is produced by large grit sandblasting with $0.25-0.5 \mathrm{~mm}$ corundum particles at 5 bar (Wennerberg et al., 2011). A chemically altered surface based on the sandblasted and acid-etched Straumann Institute surface has been revealed to exhibit increased surface free energy and hydrophilicity, mainly due to reduced hydrocarbon contamination (Rupp et al., 2006). Acid etching of the implant surface can be used after sandblasting to produce a clean and rough surface with subsequent better osseointegration (Orsini et al., 2000; Jemat et al., 2015). The microtopographic surface structure is attributable to a subsequent process of acid etching with $\mathrm{HCl} / \mathrm{H}_{2} \mathrm{SO}_{4}$ at high temperatures (Fischer and Stenberg, 2012), creating a rough surface with an active surface area and improved cell adhesion (Abraham, 2014). A comparable approach is used to produce a surface topography with $1.3 \mu \mathrm{m}$ microroughness (Dohan Ehrenfest et al., 2011), such as the Camlog Promote surface (Camlog, Basel, Switzerland). Buser et al. (1991) found that surface modification of an implant with SLA had superior BIC than numerous other surface alterations such as electropolishing or titanium plasma-sprayed implants. Li et al. (2002) revealed that the values of removal torque were considerably enhanced in SLA implants compared to machined and acid-etched implants. Fischer and Stenberg (2012) evaluated the clinical outcomes of 139 SLA implants in 24 edentulous patients over a 10-year period. They noticed that the survival rate of an implant was $95.1 \%$ and that there was a $1.07 \mathrm{~mm}$ mean of bone loss. In 303 partially edentulous patients over a 10-year period, Buser et al. (2012) assessed the clinical outcomes of 511 SLA implants. They showed that the implant has a $98.8 \%$ survival rate. In 120 patients, Cochran et al. (2011) installed 385 SLA implants. They reported a success rate of $98.8 \%$ after 5 -year follow-up. In a retrospective study performed by Lixin et al. (2010), 353 implants with the Camlog Promote surface were positioned in 40 edentulous patients, and the survival rate was 99.2\% after 4-year follow-up.

The FRIADENT plus surface (DENTSPLY Implants, Mannheim, Germany) is an example of a grit-blasted, acidetched, and neutralized implant surface that has been adjusted for use in DENTSPLY's ANKYLOS, XiVE, and FRIALIT implant systems (Figure 2). It is manufactured by large grit blasting (354-500 $\mu \mathrm{m}$ ), followed by etching in $\mathrm{HCl}, \mathrm{H}_{2} \mathrm{SO}_{4}, \mathrm{HF}$, and $\mathrm{H}_{2} \mathrm{C}_{2} \mathrm{O}_{4}$, and, finally, an exclusive neutralizing technique (Rupp et al., 2004). Junker et al. (2009) found that the macroroughness is interspersed with uneven micropores $2-5 \mu \mathrm{m}$ in size.

Streckbein et al. (2014), in their beagle dog model, assessed the formation of bone adjacent to four implant types and found that the BIC was not significantly influenced. In a minipig model, Mendonça et al. (2008) displayed that FRIADENT plus-surfaced implants had successful osseointegration under the advanced clinical condition of immediate loading. After 4 months of healing, Neugebauer et al. (2006) found that immediately loaded implants demonstrated an even higher degree of bone formation and remodeling than unloaded implants. Novaes et al. (2004)
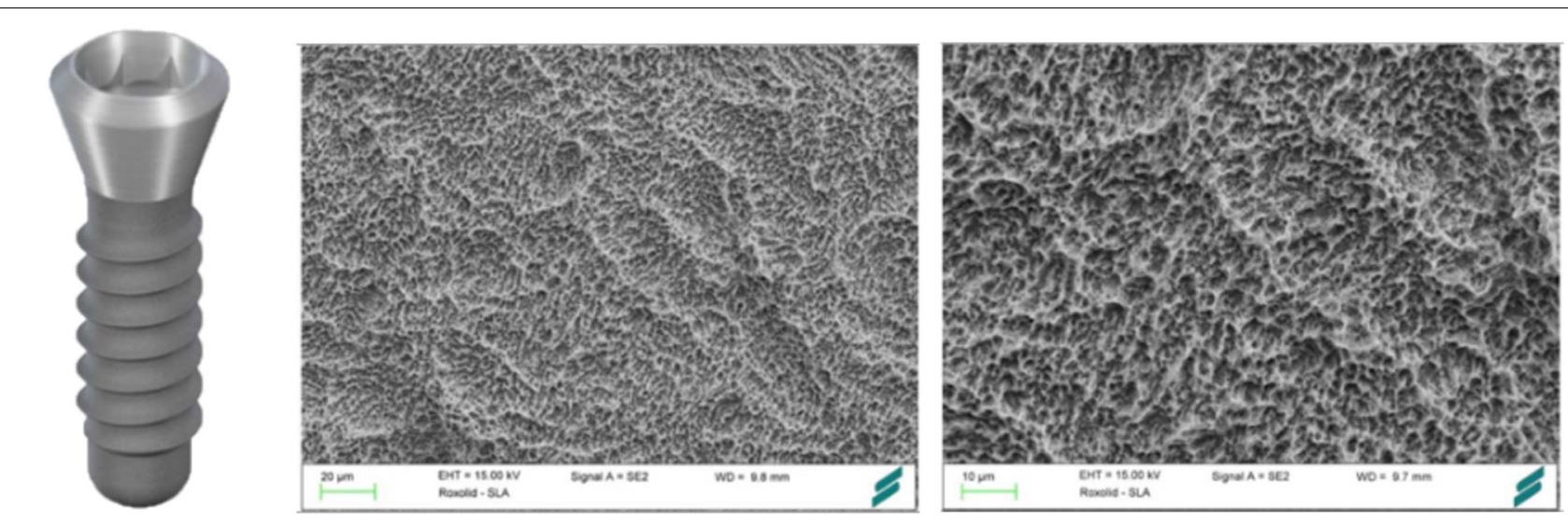

FIGURE 1 | Surface features and scanning electron micrographs of a Roxolid implant with SLA surface. 

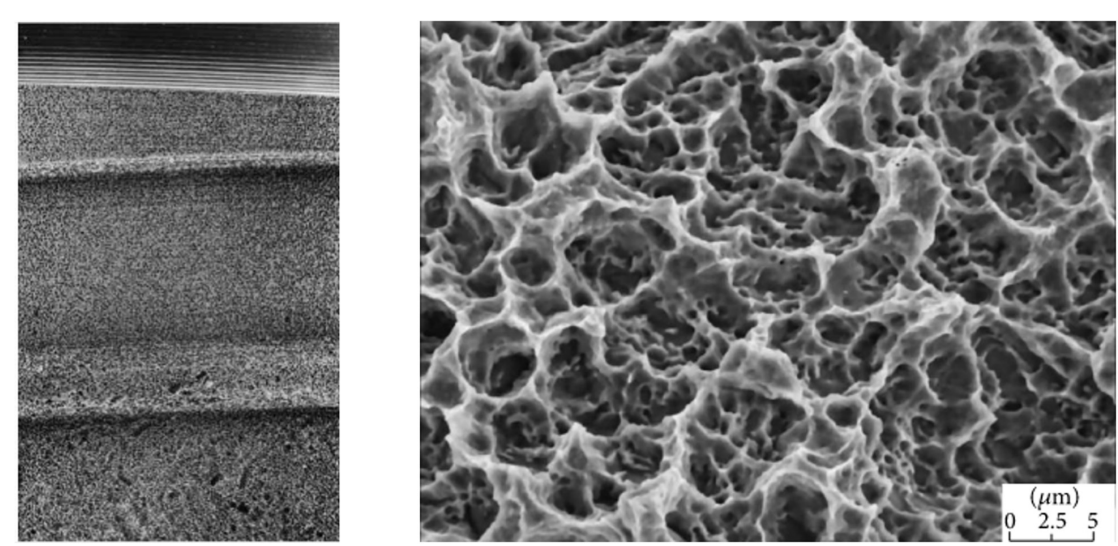

FIGURE 2 | Surface features and scanning electron micrographs of a FRIADENT plus surface.

revealed that FRIADENT plus-surfaced implants used in a dog model of periodontitis achieved an acceptable BIC. Degidi et al. (2006), in their clinical study, compared the FRIADENT plus implant with three different DENTSPLY implant types. Based on parameters of primary implant stability, 802 implants were assigned to an immediate or delayed loading protocol. They found that the overall success rate for the FRIADENT plus implant was $99.6 \%$ after 1 year of placement.

Some authors treated Ti implants with fluoride solutions as another possibility for enhancing bone integration because $\mathrm{Ti}$ is very sensitive to fluoride ions, creating soluble $\mathrm{TiF}_{4}$ species. Modification of the surfaces of a $\mathrm{Ti}$ implant with fluoride produced a combination of surface roughness and fluoride that encouraged the osseointegration process of the implant (Ellingsen, 1995; Ellingsen et al., 2004). Other studies elsewhere also found improved biomechanical anchorage and enhanced bone integration (Ellingsen et al., 2004; De Bruyn et al., 2013; Han et al., 2016). Additionally, the immersion of the implant in a fluoride solution can lead to osteoblastic differentiation (Cooper et al., 2006). Conversely, Affairs (ADA Council on Scientific Affairs, 2003) reported that fluoride adversely affected the protective oxide layer on the surface of a Ti implant.

To improve the mechanical properties of an implant, ion implantation methods are used. Sioshansi (1987) implanted nitrogen into $\mathrm{Ti}$ and noticed a considerable reduction in wear. Buchanan et al. (1990) implanted iridium into a Ti-6Al-4V alloy to increase its corrosion resistance. Jabbari et al. (2012) found that implanted dental materials coated with titanium nitride and/or nitrogen ions potentially offer superior advantages to uncoated counterparts.

\section{Modification of Implant Surface Roughness at the Nanoscale Level}

Recent efforts in dental implantation have emphasized the significance of nanotechnology in modifying the surface morphology to achieve better similarity to the surface roughness characteristics of the natural bone and to favor positive integration with cells (Özcan et al., 2012; Rani et al., 2012; Huang et al., 2013; Dalby et al., 2014; Li et al., 2015; Shen et al., 2015;
Zhao et al., 2015). The alteration of implant surface roughness at the nanoscale level is believed to affect cell-implant integrations at the protein and cellular levels (Mendonça et al., 2008).

Previous studies found that materials based on $\mathrm{TiO}_{2}$ are particularly significant for surface alteration due to their thermal stability, high corrosion resistance, and good osseointegration properties (Lee H. et al., 2010; Lee K. et al., 2014; Brammer et al., 2012; Kiran et al., 2012; Tan et al., 2012; Wang et al., 2012; Jemat et al., 2015; Das et al., 2018), as shown in Figure 3. $\mathrm{TiO}_{2}$ materials of different nanoarchitectures, including nanofibers (TNFs), nanotubes (TNTs), and nanowires (TNWs), have been intensively investigated for implant fabrication (Lee $\mathrm{H}$. et al., 2010; Lee K. et al., 2014; Brammer et al., 2012; Kiran et al., 2012; Tan et al., 2012; Wang et al., 2012; Jemat et al., 2015; Das et al., 2018). $\mathrm{TiO}_{2}$ TNT layers are specifically studied because of their facile synthesis, the ability to control their length, diameter, and microstructure, and their improved cellular responses. The improvement in encouraging cellular behavior has been confirmed with the utilization of various types of cells, for instance, chondrocytes, osteoblasts, fibroblasts, mesenchymal stem cells, and endothelial cells (Park et al., 2007; Das et al., 2009; Peng et al., 2009; Brammer et al., 2010; Smith et al., 2011; Azadmanjiri et al., 2016). The $\mathrm{TiO}_{2} \mathrm{TNW}$ and TNF coatings can be shaped on the implant surfaces due to their large surface to volume ratio, high porosity, and morphology, which is comparable to the usual extra-cellular matrix (Azad et al., 2010;
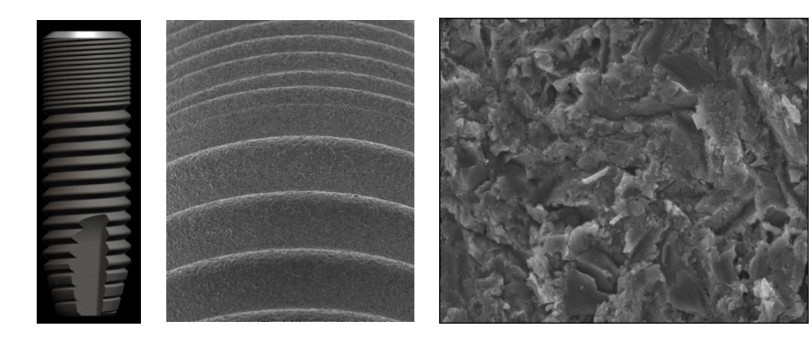

FIGURE 3 | Surface features and scanning electron micrographs of a OsseoSpeed dental implant surface. 
Tavangar et al., 2011; Pramanik et al., 2012). TNWs and TNFs can be produced by using an electrospinning method, hydrothermal treatment, anodization, laser ablation, and gas-phase reactions (Tan et al., 2013).

Many studies stated that the alteration of surface roughness of a dental implant at the nanoscale level stimulates cell adhesion and protein adsorption (Anselme et al., 2002; Bigerelle et al., 2002; Zhu et al., 2004; Zhang et al., 2013a,b) and thereby potentially promotes osseointegration (Puckett et al., 2008; Park et al., 2009; McNamara et al., 2010). This modification alters the implant's surface interaction with proteins, ions (i.e., configuration, adsorption, bioactivity, etc.), and cells. Further advancements in the surface design of dental implants are critical to improve the outcomes of sophisticated clinical situations such as implantation immediately after tooth extraction and initial loading protocols and in patients with compromised bone or impaired wound healing abilities (Gomez-de Diego et al., 2014).

Nanosurface modification of dental implants induces chemical and biological interaction between the surface of a dental implant and cells, biomolecules, and ions. These cellular and tissue interactions enhance the mechanical stability and biological functionality of nanosurface implants compared to conventional implants (Ji and Gao, 2004; Wei and Ma, 2008). Compared with traditional implants, nanotechnological modification of dental implants reduces the time needed before loading. This advantage is due to the structural similarity between the implant surface and the surface topography of the ECM within natural tissue, which is typically between 10 and $100 \mathrm{~nm}$ in size (Tomisa et al., 2011). Moreover, the nanostructure implants enhance early osseointegration, tissue engineering, and mechanical stability compared with conventional implants (Gutwein and Webster, 2004). This structure-mimicking has been demonstrated to induce cell interactions, such as adhesion, proliferation, and differentiation, that are essential to improve osseointegration. Moreover, a nanostructure implant may play a role in preventing bacterial infection associated with implants. The size and shape of nanoparticles prevent bacterial adhesion due to its antimicrobial activity (Pal et al., 2007). Studies have shown a marked decrease in bacterial adhesion and biofilm formation on nanostructured $\mathrm{TiO}_{2}$ compared with conventional $\mathrm{TiO}_{2}$ implants, regardless of the fact that these nanosurface implants encourage osteoblast adhesion and differentiation. Implants with nanophase $\mathrm{TiO}_{2}$ surfaces have antimicrobial activity against oral infections ( $S$. aureus and $P$. aeruginosa). On the other hand, it increased osteoblast adhesion and proliferation (Bhardwaj and Webster, 2017). Tsimbouri et al. (2016) used hydrothermal oxidation to produce $\mathrm{TiO}_{2}$ nanowires and reported a decrease in $P$. aeruginosa growth in the early stage of bacterial adhesion compared to Ti with a polished surface. Truong et al. (2010) found that prokaryotic and eukaryotic cell attachment on Ti surfaces can be organized by altering the topography of the surface into micro- or nano-structures. Furthermore, the addition of silver nanoparticles into $\mathrm{TiO}_{2}$ nanotubes contributes long-term antimicrobial activity to implants. The antibacterial activity of silver is via the induction of reactive oxygen species (Shokuhfar et al., 2014).

Some implant producers have increased surface roughness through Discrete Crystalline Deposition (DCD). The NanoTite implant is fabricated by BIOMET 3i, Palm Beach Gardens, FL, United States (Figure 4). Calcium phosphate $(\mathrm{CaP})$ particles $20-$ $100 \mathrm{~nm}$ in size are placed on a double acid-etched surface by DCD. This technique makes the surface area about $50 \%$ rough due to the deposition of CaP particles (Bonfante et al., 2013) and achieves a greater adhesive force to the surface of the implant than previous CaP deposition methods (Kitsugi et al., 1996; Franchi et al., 2004). Rodriguez y Baena et al. (2012) Evaluated bacterial adhesion on machined titanium, OsseoTite, and NanoTite discs and found that bacterial adhesion to the NanoTite surface was lower than to the predecessor Osseotite surface.

Mendes et al. (2007) found in the distal femur of rats that the disruption force at the bone-implant interface was significantly higher in bone-bonding to $\mathrm{Ti}$ surfaces fabricated by $\mathrm{DCD}$ of $\mathrm{CaP}$ nanocrystals compared to non-DCD samples. Mendes et al. (2009) also found improved osteoconduction of DCDtreated implants than the predecessor control. In a rabbit model, Calvo-Guirado et al. (2015) showed only a tendency of improved
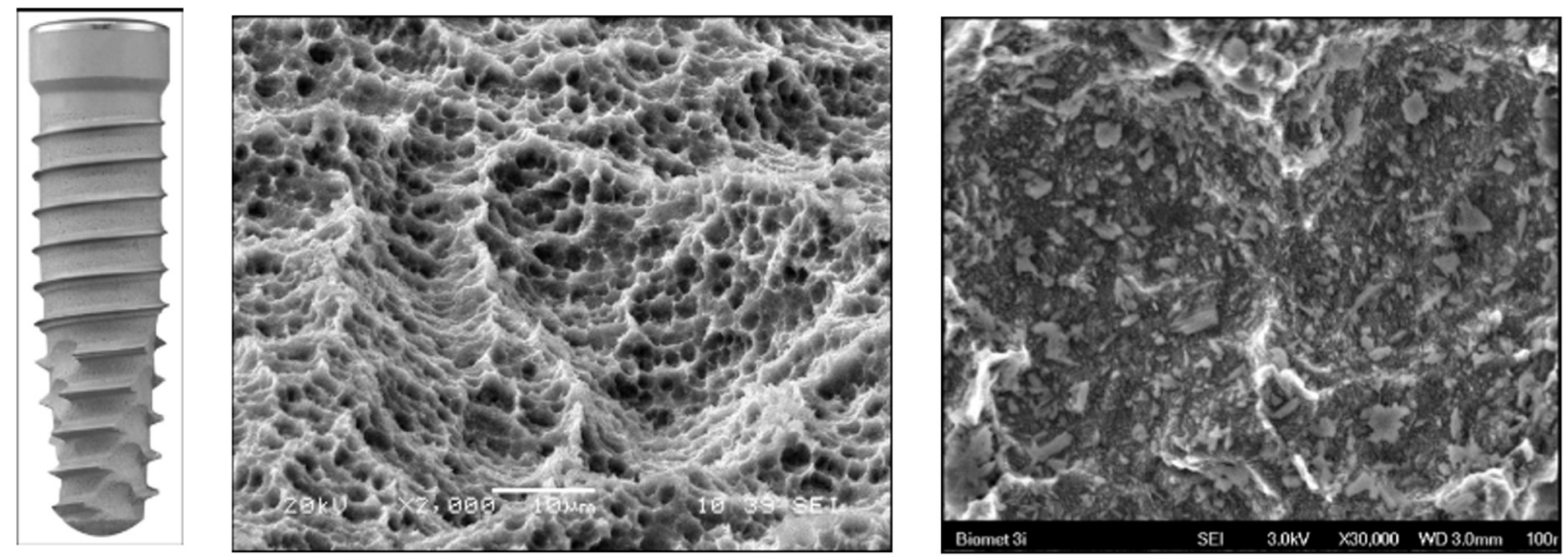

FIGURE 4 | Surface features and scanning electron micrographs of a BIOMET dental implant surface. 

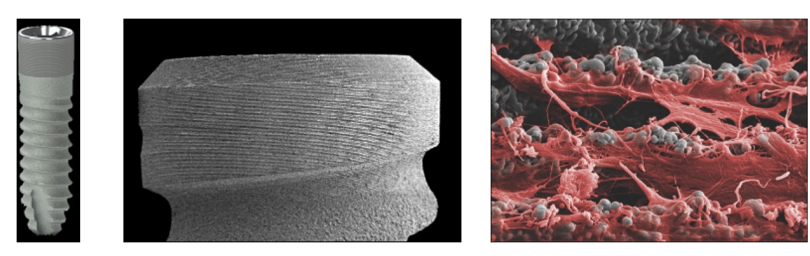

FIGURE 5 | Surface features and scanning electron micrographs of a Laser-Lok dental implant surface.

BIC for DCD implants. In a prospective 1-year clinical trial, Östman et al. (2013) placed 139 NanoTite tapered implants in 42 patients and found the survival rate to be $99.4 \%$, with an average marginal bone resorption of $1.01 \mathrm{~mm}$. The same authors (Östman et al., 2010) found a survival rate of $94.9 \%$ for 335 NanoTite implants placed in 185 patients after 1-year follow-up.

To improve the roughness of Ti implant surfaces, another approach is to apply various laser-based techniques (Baeuerle, 2000). Lasers are used for the ablation of surfaces because of the perfect control of the light frequency achievable, the capability to focus and rasterize the light, the high energy density, the wide range of frequencies available, and the capability to pulse the source and control the reaction time. Lasers frequently applied for surface alteration are ruby, $\mathrm{Nd}: \mathrm{YAG}, \mathrm{CO}_{2}$ argon, and excimer (Gaggl et al., 2000; György et al., 2002).

The Laser-Lok implant (BioHorizons, Birmingham, AL, United States) is an example of a laser ablation surface (Figure 5). This implant has been treated in a laser micromachining step to produce a pattern of micro- and nanoscale microchannels. Nevins et al. (2010) revealed that the creation of connective tissue adjacent to Laser-Lok abutments is structured in a perpendicular way. In 15 patients, Pecora et al. (2009) placed 20 Laser-Lok implants and found growth in connective tissue around the implants. Other authors also found that microtextured implant collars have a favorable effect on soft tissue attachment and crestal bone maintenance (Botos et al., 2011; Guarnieri et al., 2014).
After 2-year follow-up, Farronato et al. (2014) reported a rate of survival of $96.1 \%$ for Laser-Lok dental implants.

Other implant producers increase surface roughness through a chemical process called anodization. This involves the dielectric breakdown of $\mathrm{a} \mathrm{TiO}_{2}$ layer by applying an increased voltage to produce a micro-arc and creates a porous layer on the surface of the $\mathrm{Ti}$ implant with significantly increased oxidation ( $\mathrm{Li}$ et al., 2004). This modification has been shown to increase BIC (Sul et al., 2002; Wennerberg et al., 2015; Smeets et al., 2016), biocompatibility, cell adhesion, and bone formation (Gupta et al., 2010). The following procedures should be followed: "decontaminating the implant surface from the organic and inorganic impurities that could affect the formation of the oxide layer," (Mandracci et al., 2016) "avoiding ion release to the surrounding hard and soft tissues, increasing the corrosion resistance, improving the wear resistance, and increasing the biocompatibility and bone formation with the possibility of adding $\mathrm{Mg}$, which is vital for the absorption of calcium minerals in bone cells" (Shayganpour et al., 2015).

The TiUnite implant (Nobel Biocare Holding AG, Zurich, Switzerland) is an example of anodization (Figure 6). The surface of this implant is electrochemically altered by anodic oxidation to increase the thickness of the $\mathrm{TiO}_{2}$ layer to $600-1000 \mathrm{~nm}$ rather than the 17-200 $\mathrm{nm}$ in traditional titanium implants (Sul et al., 2002). The terms Ti porous oxide (Rocci et al., 2013) or anodized Ti surface implant (Zechner et al., 2003) have also been used to refer to this type of implant surface. TiUnite implants have been shown to possess nanoscale surface characteristics (Sul et al., 2008). Ti surfaces generated at the nanoscale level by anodic oxidation have been found to augment the proliferation, adhesion, and extracellular matrix deposition of human gingival fibroblasts (Guida et al., 2013).

Sul et al. (2002) have shown in a rabbit model that the BIC with anodized implant surfaces is somewhat superior to that with pure $\mathrm{Ti}$ implants that are available commercially. These findings were confirmed by Zechner et al. (2003). The BIC of TiUnite implants was significantly greater than that of machined implants 6 and 12 weeks after implant placement (Rocci et al.,
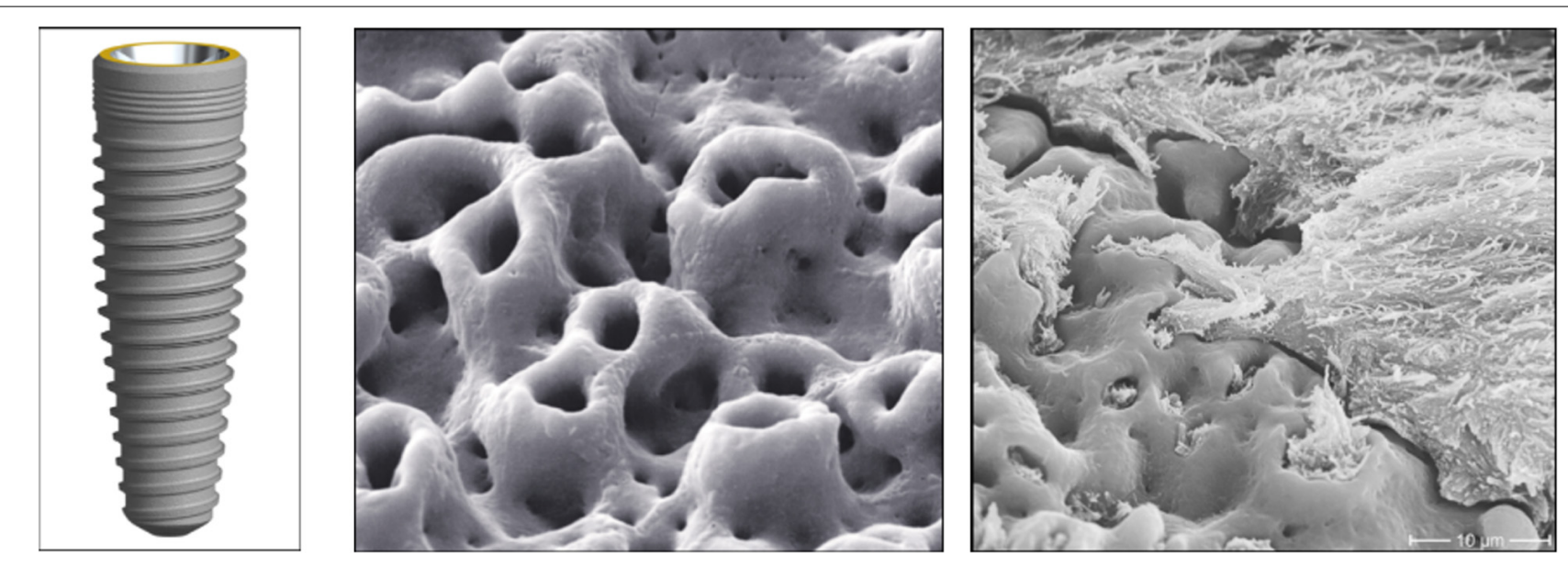

FIGURE 6 | Surface features and scanning electron micrographs of a TiUnite dental implant surface. 
2013). Ivanoff et al. (2003) showed an increased BIC with TiUnite microimplants compared to machined titanium microimplants. They found a considerably greater BIC around anodized implants in the maxilla and the mandible. Jungner et al. (2005) found that the survival rate for TiUnite implants was 100\% after 5-month follow-up. In spite of the increased roughness of the anodized surface, the surface with porous oxide does not assist improved biofilm formation (Quirynen and Van Assche, 2012).

Recently, Ozdemir et al. (2016) introduced Chemical Mechanical Polishing (CMP) as another method for bio-implant surface structuring. Schmutz et al. (2008) found in their study that CMP could encourage the synergistic influence of surface nanostructuring while changing the chemistry of the surface to reduce the corrosion of the surface and ion dissolution through the promotion of the creation of a self-protective surface oxide film.

\section{Calcium Phosphate-Coated Implants}

The combination of $\mathrm{HA}$ coating with $\mathrm{Ti}$ alloy implants has received attention because of its attractive characteristics, such as increased biocompatibility and good mechanical properties (Simmons et al., 1999; Poinern et al., 2009). Histological studies performed by some researchers in dogs showed that implants coated with HA provided more rapid bone formation after 1 and 4 months compared to uncoated implants (Block et al., 1987, 1989). After 6 months, in the healed sites of the molar region of rhesus monkeys, Lum et al. (1991) also observed that HA-coated implants were associated with direct contact with the bone.

Various procedures have been established to coat Ti implants, for instance, sol-gel coating, plasma spraying, electrophoretic deposition, sputter deposition, or biomimetic precipitation. Among these methods, only plasma-spraying has been used for Ti implants in clinical practice. This allows a thickness from a few micrometers to a few millimeters to be deposited on the implant surface (Knabe et al., 2002; Le Guehennec et al., 2007). Even though Ti implants coated with HA layers by plasma spraying have provided favorable results (De Groot et al., 1987; Freeman, 1992), this method has some shortcomings, such as coating delamination. In addition, the remarkably high temperatures (above $10,000^{\circ} \mathrm{C}$ ) involved in creating the HA coatings make combination with biologically active molecules difficult. Furthermore, HA-coated implants are more prone to colonization by the bacteria compared to uncoated Ti implants owing to their surface roughness and hydrophilicity (Johnson, 1992). The inconsistency in dissolution between the different phases that create the coating has led to particle release and delamination, and therefore the implants may fail clinically (Wheeler, 1996; Tinsley et al., 2001). Moreover, a number of investigators have claimed that HA coatings are more prone to bacterial infection, are unstable, and might be prone to rapid bone failure (Jovanovic et al., 1993; Wolinsky et al., 1989).

Nevertheless, many clinical studies reported that implants coated with HA promote faster bone attachment, have a higher integration rate, and achieve more direct bone bonding than uncoated implants (Golec and Krauser, 1992; Duraccio et al., 2015). However, there are many controversies about the long-term prognosis of coated implants (Aoki, 1991; Buser et al., 1991; Matsui et al., 1994; Wheeler, 1996; Tsui et al., 1998a).
Wheeler (1996) showed that the survival rate was initially more for HA-coated implants but reduced considerably after 4 years. In addition, Matsui et al. (1994) reported signs of the covering material of HA-coated implants separating from the implant surface, which might encourage foreign body reactions (Buser et al., 1991; Matsui et al., 1994). Tsui et al. (1998a,b) reported finding some amorphous and metastable phases in the HA coating produced through the plasma-spraying procedure and inferred that may account for the poor mechanical strength and low crystallinity of HA coatings (Aoki, 1991). Despite the negative reputation of plasma-sprayed HA-coated implants in dental practice, Lee et al. (2000), in their meta-analytic review, revealed that their long-term survival rates were not lower than those of other types of implant.

\section{Surface Wettability}

Among the various surface alterations of Ti implants (Junker et al., 2009), many have been established to increase surface wettability or hydrophilicity. "Wettability is measured by contact angle measurement, usually of water, at the solid/liquid interface while surrounded by a gas phase or another liquid phase and provides gross surface characterization" (Gittens et al., 2014). Many studies have confirmed the role of wettability or hydrophilicity at the protein and cellular levels (Sawase et al., 2008; Aita et al., 2009; Olivares-Navarrete et al., 2012; Hirakawa et al., 2013; Gittens et al., 2014). These studies showed that hydrophilic surfaces could improve the early stages of cell adhesion, differentiation, and proliferation as well as bone mineralization (Eriksson et al., 2004; Bornstein et al., 2008). After 1 week and up to 2 weeks, Schwarz et al. (2007a) confirmed that hydrophilic surfaces produce superior performance compared to hydrophobic surfaces, with higher BIC. Tugulu et al. (2010) treated the implant surface with diluted alkaline solution and found that the hydrophilic surface reduced the adhesion of the fibrinogen and thereby reduced the inflammation around the implant. Olivares-Navarrete et al. (2012) studied the effects of surface characteristics such as surface roughness and wettability and found significantly higher BIC for surfaces with these characteristics compared to machined surfaces.

Straumann Holdings AG, Basel, Switzerland introduced the SLActive dental implant (Figure 7). Its surface is modified to a higher level of hydrophilicity from the standard large gritblasted and acid-etched SLA implant (Wennerberg et al., 2011). Wennerberg et al. (2011) claimed that the hydrophilic SLActive surface stimulates the maturation of osteogenic cells and cell adhesion, encourages a bone-forming microenvironment, and fosters neoangiogenesis. In a dog model, Schwarz et al. (2007b) found that SLActive implants achieved higher affinity of the initial blood clot to the implant surface, improved neoangiogenesis, increased BIC, and better bone density compared to SLA implants within the first 2 weeks of bone healing. At 2 and 4 weeks after implant placement, Buser et al. (2004) showed that SLActive implants had a higher BIC compared to SLA implants. After 12 weeks of implant placement, Calvo-Guirado et al. (2010) found a better BIC and less crestal bone resorption for hydrophilic implants. 


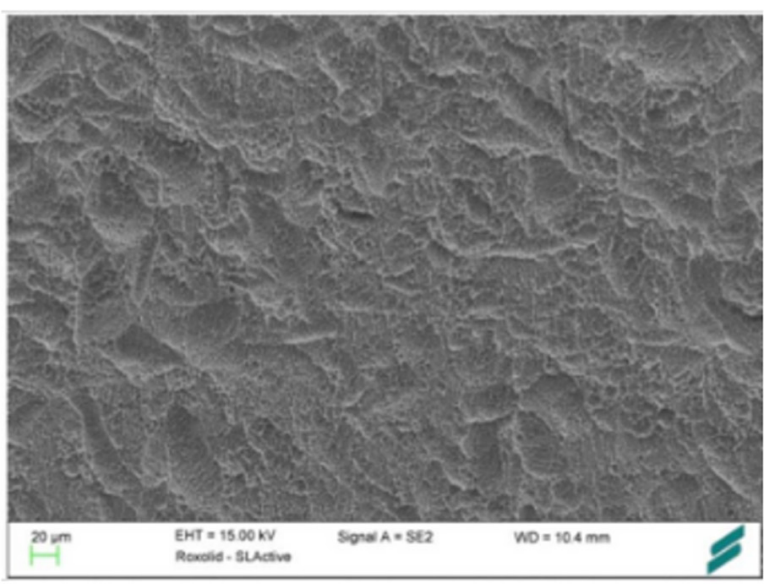

FIGURE 7 | Scanning electron micrographs of a SLActive dental implant surface.

\section{BIOMIMETIC PROCESS}

The common feature of the implants on the market is rough surfaces created through physical or chemical modification. The enhanced performance of these implants can mainly be assigned to increased stimulation of bone anchorage, since rough surface topographies have an influence on osteogenic cells and platelet activation (Park et al., 2001; Boyan et al., 2003). However, in situations where exactly these mechanisms are impaired, e.g., at implantation sites with low bone density, low vascularization, or insufficient bone quantity, there is still a potential to improve cell adhesion to the implant surfaces (Morra, 2007). Achieving appropriate cell adhesion to the surface is particularly important in order to cause the surface to be occupied by living cells, therefore making it less susceptible to bacterial colonization (Gristina, 1987).

The investigation of the remarkable properties of natural and novel artificial hard tissues has the potential to give insight into biomimetic material design and the development of novel functional materials (Nazarpour, 2013). Therefore, recent trends in the development of modern implants are to fabricate dental implants with biological and biomechanical behaviors that mimic those of natural tooth under function (Huang et al., 2007; Nazarpour, 2013).

\section{Biomimetic Calcium Phosphate-Coated Implants}

The success of implants depends critically on the surface alteration, which is correlated to osteoconductivity and osteoinductivity. Osteoconduction is defined as "the ability to grow bone on the surface of an implanted material or scaffold. This process is particularly important to the fields of dentistry and bone biology as it is necessary for implant replacement" (Wilson-Hench, 1987). Osteoinduction means "that primitive, undifferentiated, and pluripotent cells are somehow stimulated to develop into the bone-forming cell lineage. One proposed definition is the process by which osteogenesis is induced"

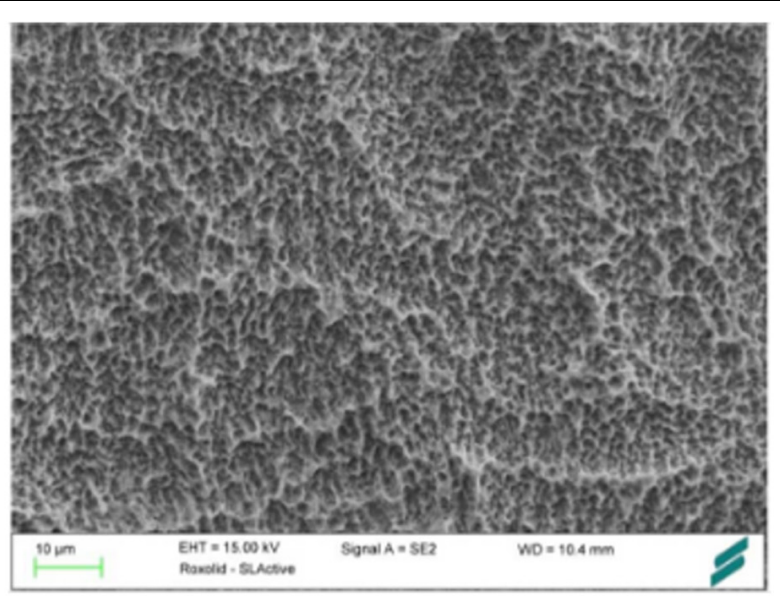

(Williams, 1987). Huge developments have been accomplished in the osteoconductivity of implants by coating their surfaces with a layer of CP (Wong et al., 1995). However, the approaches used to deposit a CP layer on the implant surfaces, for instance, plasma spraying, hot isostatic pressing, sol-gel deposition, ion-assisted deposition, high-velocity oxy-fuel spraying, electrochemical deposition, sputter coating, electrophoretic deposition, and pulsed laser deposition (Wolke et al., 1994, 1998a,b), are markedly non-physiological owing to the high temperatures involved. These high temperatures prevent the integration of a biological agent, for example, an osteogenic growth factor. Therefore, in most circumstances, biological agents can only be absorbed directly onto the implant surfaces (Kawai et al., 1993; Ripamonti et al., 1993; Hollinger et al., 1998; Noshi et al., 2001).

In recent times many methods have been trialed for the deposition CP layers on the surfaces of $\mathrm{Ti}$ implants under more physiological or "biomimetic" temperature and $\mathrm{pH}$ conditions (Barrere et al., 1999; Wen et al., 1999). Furthermore, the structure of the crystals made (carbonated apatite) is more akin to that of bone mineral than are those of HA and tri- or tetraCP (Nagano et al., 1996), which are produced at exceedingly high temperatures.

In order to overcome the disadvantages of other coating methods, researchers established new coating methods based on a biomineralization process, using simulated body fluids (SBF) to precipitate calcium phosphate crystals onto the Ti surface to form a thin coating at room temperature (Le Guehennec et al., 2007).

Generally, biomimetic deposition is "a solution-based method conducted in an environment that mimics the human body condition. In most cases, such [a] body-like environment is provided by an $\mathrm{SBF}$ at $37^{\circ} \mathrm{C}$. The temperature, $\mathrm{pH}$, and other parameters of the conditions for biomimetic deposition are carefully controlled to simulate the body environment" (Sharifi et al., 2016). Biomimetic synthesis of calcium phosphate on Ti implants with the aim of increasing biocompatibility and promoting osseointegration (Bigi et al., 2005; Zhang et al., 2005; Forsgren et al., 2007). Many biomimetic methods have been applied and reported for the precipitation of $\mathrm{CP}$ apatite 
crystals onto the Ti surface from SBF to form a coating at room temperature (Leeuwenburgh et al., 2001; Ágata de Sena et al., 2002; Habibovic et al., 2002; Wang et al., 2003, 2004; Barrere et al., 2004; Yang et al., 2004; Bose and Tarafder, 2012; Shadanbaz and Dias, 2012). In preclinical models, the osseointegration of Ti implants coated with biomimetic $\mathrm{CP}$ has been examined (Barrere et al., 2003; Habibovic et al., 2005).

Many studies found that the biomimetic coating procedure is cost-effective and easy to achieve and can be used even for heatsensitive, non-conductive, and porous materials of large sizes and with complex surface geometries. This technique has the capability to integrate biologically active molecules, which can be co-precipitated with the inorganic components. However, the structure of the coating could be affected by the coating time, and the coating process takes days (Barrere et al., 2001; Liu et al., 2001; Waterman et al., 2011; Habraken et al., 2013).

\section{Biomimetic Surface Modification}

Several biologically functional molecules can be immobilized onto Ti surfaces to improve the regeneration of the bone at the implant device interface (Puleo and Nanci, 1999; Jenny et al., 2016). However, Meng et al. (2016) concluded that bioactive surface alterations on implant surfaces do not have a permanent favorable influence on osseointegration. On the other hand, some investigators reported that surface modifications of Ti implants with biologically functional molecules appear to stimulate periimplant bone formation, causing improved osseointegration throughout the initial phases of healing. Therefore, clinical reports with long-term follow-up are desirable to confirm this result (Matarese et al., 2017; Cicciù et al., 2018).

Natural extracellular matrix (ECM) contains multiple types of biomolecules, for example, adhesive peptide, polysaccharide, and growth factors, which interact with cells to initiate a cascade of cell attachment, proliferation, spreading, and differentiation. Furthermore, ECM has nanoporous structures that permit attachment of cells and ingrowth and sufficient mass transport of nutrients and waste products during tissue neogenesis. Therefore, producing biomimetic ECM may be an effective technique for increasing the bioactivity of implant devices. A mixture of multiple biologically functional molecules and nanostructures is preferred for biomimetic ECM to generate the best microenvironment for cell affinity and for regulating cellular functions (Wang et al., 2016).

Many strategies for organic coating are used, such as the immobilization of ECM peptide or proteins (collagen, etc.) as modulators for bone cell adhesion, immobilization of DNA for structural reinforcement, deposition of cell signaling agents to activate new bone formation, and enzyme-modification of $\mathrm{Ti}$ surfaces for improved bone mineralization (de Jonge et al., 2008; Wennerberg et al., 2015). Sooner or later, bone implant surfaces will be enhanced with biologically functional molecules to promote the bone healing procedure (Coelho et al., 2009; Wennerberg and Albrektsson, 2009; Ehrenfest et al., 2010).

\section{Modification of Implant Surfaces With ECM Proteins}

ECM proteins are involved in diverse processes with respect to cell adhesion, multiplication, and differentiation
(Stevens and George, 2005; Morra, 2006; Frantz et al., 2010). In native tissues, ECM presents its adhesion proteins, for example laminin, fibronectin, collagen, and vitronectin, to effect cell attachment through the binding between integrin receptors on cell surfaces. Therefore much work is being done to enhance the biocompatibility of polymeric tissue-engineered scaffolds to create a biochemical-like environment on the biomaterial surface (Ma et al., 2005).

Type I collagen may be one of the major applicable biomaterials for realizing tissue-engineered grafts and is one of the proteins that play critical roles in the mineralization of bone (Scarano et al., 2017a), bone healing (Ao et al., 2016), osteoblastic adhesion and differentiation, enhancing blood compatibility, and extracellular-matrix secretion (Maghdouri-White et al., 2014). Table 2 shows the influence of implant surfaces modified with ECM proteins.

Morra et al. (2006) examined the influence of collagen incorporation on anodized Ti surfaces in rabbit femur trabecular bone. They found that surface modification with collagen can enhance osseointegration. However, Alghamdi et al. (2013) concluded that implant surfaces alternating with collagen did not improve the formation of peri-implant bone in the mandibles of dogs. Schliephake et al. (2006) coated machined Ti implant with a composite of $\mathrm{CP}$ and collagen (I) and found enhancement in BIC and peri-implant bone formation. Lee S.W. et al. (2014) evaluated the effects of implant surfaces coated with HA and type I collagen on peri-implant bone formation and found considerably enhanced new bone formation and BIC. Stadlinger et al. (2007) examined the effect of ECM coatings on implant stability and osseointegration. They stated that bio-functional coating of the implant surface with bisphosphonate, $\mathrm{CP}$, or collagen containing chondroitin sulfate appeared to have the ability to improve peri-implant bone healing. Stadlinger et al. (2008b) assessed the effect of immobilizing ECM components on implants in pigs. They implied that implant surfaces coated by collagen containing chondroitin sulfate might result in a higher degree of bone formation. In pigs, Stadlinger et al. (2008a) examined whether the addition of recombinant human bone morphogenetic protein (rhBMP-4) and chondroitin sulfate to a collagen-coated implant could further increase osseointegration. They proposed that the addition of chondroitin sulfate to a collagen-coated implant might encourage osseointegration. Stadlinger et al. (2009) tested a collagen and chondroitin sulfatecoated implant and found that it encouraged bone formation. Morra et al. (2010) tested the influence of collagen covalently linked to acid-etched implant surfaces and reported that periimplant bone formation during early healing could be enhanced. Stadlinger et al. (2012) assessed whether ECM coating on implant surfaces increases bone formation in minipigs. They reported that the coating of ECM displayed no advantageous influence in the aspects of BV density and ISQ value. Bae et al. (2018) exhibited an improvement in bone healing and osseointegration with collagen type I cross-linked by gamma irradiation. Rotenberg et al. (2016) reported that type I collagen could offer superior resistance to pre-implantitis and can be used for treating the hard tissue loss related with peri-implantitis around SLA implants. Korn et al. (2014) showed that Ti implants coated with type I collagen 
TABLE 2 | Dental implant surfaces alteration with extracellular matrix proteins.

\begin{tabular}{|c|c|c|c|c|}
\hline References & Surface modification & Study model & Study length & Results \\
\hline Morra et al. (2006) & $\begin{array}{l}\text { Collagen incorporation on anodized Ti implant } \\
\text { surfaces }\end{array}$ & Rabbits & 4 weeks & Can enhance osseointegration \\
\hline Alghamdi et al. (2013) & Implant surfaces alternating with collagen & Dogs & 1 and 3 months & $\begin{array}{l}\text { Did not improve the formation of } \\
\text { peri-implant bone }\end{array}$ \\
\hline Schliephake et al. (2006) & $\begin{array}{l}\text { Coated machined Ti implant with a composite of } \\
\mathrm{CP} \text { and collagen }\end{array}$ & Dogs & 1 and 3 months & $\begin{array}{l}\text { Enhanced BIC and peri-implant bone } \\
\text { formation }\end{array}$ \\
\hline Lee S.W. et al. (2014) & Implant surfaces coated with HA and type I collagen & Rabbits & 6 weeks & Enhanced new bone formation and BIC \\
\hline Stadlinger et al. (2007) & $\begin{array}{l}\text { ECM coatings on implant to improve stability and } \\
\text { osseointegration }\end{array}$ & Pigs & 22 weeks & Improved peri-implant bone healing \\
\hline Stadlinger et al. (2008a) & Immobilizing ECM components on implants & Miniature pigs & 6 weeks & $\begin{array}{l}\text { Showed a higher degree of bone } \\
\text { formation }\end{array}$ \\
\hline Stadlinger et al. (2008b) & $\begin{array}{l}\text { Adding of rhBMP-4 and chondroitin sulfate on a } \\
\text { collagen-coated implant }\end{array}$ & Miniature pigs & 6 weeks & Might encourage osseointegration \\
\hline Stadlinger et al. (2009) & Collagen- and chondroitin sulfate-coated implant & Miniature pigs & 1 month & Can encourage bone formation \\
\hline Morra et al. (2010) & $\begin{array}{l}\text { Collagen covalently linked to acid-etched implant } \\
\text { surfaces }\end{array}$ & Rabbits & 2 and 4 weeks & $\begin{array}{l}\text { Peri-implant bone formation during } \\
\text { early healing could be enhanced }\end{array}$ \\
\hline Stadlinger et al. (2012) & ECM coating on implant surfaces & Miniature pigs & 4 and 8 weeks & $\begin{array}{l}\text { No advantageous influence in terms of } \\
\text { BV density and ISQ value }\end{array}$ \\
\hline Bae et al. (2018) & Collagen type I cross-linked by gamma irradiation & Rats & 4 weeks & $\begin{array}{l}\text { Improvements in the bone healing and } \\
\text { osseointegration shown }\end{array}$ \\
\hline Rotenberg et al. (2016) & $\begin{array}{l}\text { Porcine collagen-coated bovine bone around SLA } \\
\text { implants }\end{array}$ & Human & 12 months & $\begin{array}{l}\text { Can offer superior resistance to } \\
\text { pre-implantitis }\end{array}$ \\
\hline Korn et al. (2014) & Ti implants coated with type I collagen & Miniature pigs & 4 and 8 weeks & $\begin{array}{l}\text { Improved early osteogenesis, improved } \\
\mathrm{BIC} \text {, and increased bone density }\end{array}$ \\
\hline Scarano et al. (2019) & Implant surface coated with type I collagen & Rabbits & $\begin{array}{l}15,30, \text { and } \\
60 \text { days }\end{array}$ & $\begin{array}{l}\text { Increased the BIC, bioactivity, and bone } \\
\text { around the dental surface }\end{array}$ \\
\hline
\end{tabular}

improved early osteogenesis. The authors also found improved BIC and increase bone density. Scarano et al. (2019) examined an implant surface coated with type I collagen in a rabbit model. They showed that surfaces coated with collagen increased the BIC, bioactivity, and bone around the dental surface compared to control implants.

\section{Modification of Implant Surfaces With Peptides}

Another approach is the functionalization of implant surfaces with Arginine-Glycine-Aspartate (RGD)-containing peptides, which represents a further method of influencing cell adhesion to the surfaces, thus improving implant-tissue interactions (Garcia and Reyes, 2005; Morra, 2006). RGD-containing peptides are an essential type of signal molecule that are normally immobilized on biomaterial surfaces to control cell performance. RGD is an amino acid sequence (Arginine-Glycine-Aspartate) that is recognized by cells through integrin receptors (Ruoslahti and Pierschbacher, 1987; Zhang et al., 2018). Table 3 shows the influence of implant surfaces modified with peptides.

Germanier et al. (2006) examined the influence of an RGDpeptide-modified polymer on implant surfaces, and, in the very early stages of bone healing following implant placement, they found more bone apposition. In the mandibles of dogs, Barros et al. (2009) examined the influence of a bio-functionalized implant surface on osseointegration. They concluded that a biofunctionalized implant surface could affect the bone apposition around implants. In adult pigs, Yang et al. (2009) assessed the effect of RGD-coated implant surfaces on bone-bonding ability. They reported that RGD-coated implants have higher
BIC. Lutz et al. (2010) tested the effect of a biomimetic active peptide (P-15) coated implant on early implant osseointegration. They concluded that implant surfaces coated with biomimetic active peptide have higher percentages of BIC and superior periimplant bone density. In rabbits, Yoo et al. (2015) investigated the effect of an implant surface coated with poly lactide-co-glycolide (PLGA) and BMP- 2 on bone growth and found that it facilitated osseointegration during initial healing.

\section{Modification of Implant Surfaces With Transforming Growth Factor- $\beta$}

Another approach to influencing the processes occurring at the implant-tissue interface is to coat the implant surface with growth factors (for instance, BMP, insulin-like growth factor, or platelet-derived growth factor) (Le Guehennec et al., 2007; Chen et al., 2013). Such growth factor coatings may be effective in modulating cellular functions by, e.g., attracting circulating osteoprogenitors or promoting the differentiation of stem cells or osteoprogenitors into osteoblasts and could therefore improve bone repair around implants (Lieberman et al., 2002; Goodman et al., 2013).

After dental implantation, various studies reported that BMP enhanced and improved osteogenesis, chondroblast activity, osteoblast activity, and osseointegration. Many researchers found that BMP-2 and BMP-7 are the most effective derivatives for inducing bone morphogenesis (Jiang et al., 2013; Ramazanoglu et al., 2013; Dolanmaz et al., 2015; Bouyer et al., 2016). They reported that local application of BMP-2 and BMP7 can achieve and promote cellular differentiation, which 
increases the capacity for bone repair in a diversity of circumstances comprising bony defects, extraction sockets, nonunion fractures, and osseointegration (Hunziker et al., 2012;
Jiang et al., 2013). BMPs (including rhBMP-2) form a monolayer on the surface of implants, which leads to cell proliferation (Urist, 1965; Sakou, 1998). Table 4 shows the

TABLE 3 | Dental implant surfaces alteration with peptides.

\begin{tabular}{|c|c|c|c|c|}
\hline References & Surface modification & Study module & Study length & Results \\
\hline Germanier et al. (2006) & $\begin{array}{l}\text { RGD-peptide-modified polymer on } \\
\text { implant surfaces }\end{array}$ & Miniature pigs & 2 and 4 weeks & $\begin{array}{l}\text { Enhanced bone apposition during the } \\
\text { early stages of bone regeneration }\end{array}$ \\
\hline Barros et al. (2009) & Bio-functionalized implant surface & Dogs & 12 weeks & $\begin{array}{l}\text { Could affect the bone apposition } \\
\text { around implants }\end{array}$ \\
\hline Yang et al. (2009) & RGD-coated implant surfaces & Rabbits & 4, 8 and 12 weeks & Have higher BIC \\
\hline Lutz et al. (2010) & $\begin{array}{l}\text { Biomimetic active peptide }(\mathrm{P}-15) \\
\text { coated implant }\end{array}$ & Pig & 14 and 30 days & $\begin{array}{l}\text { Has higher BIC and superior } \\
\text { peri-implant bone density }\end{array}$ \\
\hline Yoo et al. (2015) & $\begin{array}{l}\text { Implant surface coated with poly } \\
\text { lactide-co-glycolide (PLGA) and BMP-2 }\end{array}$ & Rabbit & 3 and 7 weeks & $\begin{array}{l}\text { Facilitates osseointegration during initia } \\
\text { healing }\end{array}$ \\
\hline
\end{tabular}

TABLE 4 | Dental implant surfaces alteration with Transforming Growth Factor- $\beta$.

\begin{tabular}{|c|c|c|c|c|}
\hline References & Surface modification & Study module & Study length & Results \\
\hline Jiang et al. (2013) & $\begin{array}{l}\text { BMP-2 coated surfaces on roughened or } \\
\text { sandblasted implant }\end{array}$ & Rabbits & $\begin{array}{l}2,4, \text { and } \\
8 \text { weeks }\end{array}$ & $\begin{array}{l}\text { Important in accelerating the } \\
\text { osteoinductivity around implants }\end{array}$ \\
\hline Kim et al. (2015) & SLA implants coating with BMP-2 & Dogs & 8 weeks & More active in improving osseointegration \\
\hline Liu et al. (2007) & $\begin{array}{l}\text { BMP-2 and its method of delivery on the } \\
\text { osteoconductivity implants }\end{array}$ & Pigs & 3 weeks & $\begin{array}{l}\text { Osteoconductivity of implant surfaces can } \\
\text { be adversely modulated by BMP-2 and its } \\
\text { method of delivery }\end{array}$ \\
\hline Hunziker et al. (2012) & $\begin{array}{l}\text { Influence of BMP-2 coated implants by various } \\
\text { delivery method on peri-implant bone formation }\end{array}$ & Pigs & $\begin{array}{l}1,2, \text { and } \\
3 \text { weeks }\end{array}$ & No benefit found for any delivery method \\
\hline Huh et al. (2012) & BMP-2 coating on anodized implants & Dogs & 8 weeks & $\begin{array}{l}\text { Increased bone formation and improved } \\
\text { implant stability }\end{array}$ \\
\hline Becker et al. (2006) & $\begin{array}{l}\text { BMP-2 immobilized by covalent and non-covalent } \\
\text { approaches on chromosulfuric acid } \\
\text { surface-enhanced implant surfaces }\end{array}$ & Dogs & 4 weeks & $\begin{array}{l}\text { Surfaces appeared to be stable and } \\
\text { stimulated direct bone apposition in a } \\
\text { concentration-dependent manner }\end{array}$ \\
\hline Lan et al. (2006) & $\begin{array}{l}\text { Effect of BMP-2 coated implants on bone-implant } \\
\text { osseointegration }\end{array}$ & Rabbits & 12 weeks & $\begin{array}{l}\text { Increased the quality and quantity of } \\
\text { implant-bone osseointegration }\end{array}$ \\
\hline Wikesjö et al. (2008a) & $\begin{array}{l}\text { BMP-2 adsorbed onto a Ti porous oxide implant } \\
\text { surface }\end{array}$ & Dogs & 8 weeks & Induced peri-implant bone remodeling \\
\hline Wikesjö et al. (2008b) & BMP-2-coated Ti porous oxide implant surfaces & Monkeys & 16 weeks & Improved local bone formation \\
\hline Lan et al. (2007) & rhBMP-2 and rhlGF-1 or rhbFGF & Rabbits & 4 and 8 weeks & $\begin{array}{l}\text { rhBMP-2 capable of acting synergistically } \\
\text { with rhlGF-1 and rhbFGF to enhance } \\
\text { osseointegration }\end{array}$ \\
\hline Xing et al. (2017) & $\begin{array}{l}\text { Biofunctionalized polyelectrolyte multilayers (PEMs) } \\
\text { with polyethylenimine as the excitation layer and } \\
\text { gelatin/chitosan loaded with IGF1 on the surface of } \\
\text { a titanium implant }\end{array}$ & Rats & 8 weeks & $\begin{array}{l}\text { New implants can promote } \\
\text { osseointegration in osteoporotic conditions } \\
\text { and provide a new strategy for implant } \\
\text { repair in osteoporotic patients. }\end{array}$ \\
\hline Anitua (2006) & PRGF on the surface of an implant & Goats & 8 weeks & Enhanced osseointegration \\
\hline Park et al. (2006) & $\begin{array}{l}\text { Anodized implants coated with fibroblast growth } \\
\text { factor-fibronectin (FGFFN) fusion protein }\end{array}$ & Rabbits & 12 weeks & Will possibly improve osseointegration \\
\hline Nikolidakis et al. (2009) & $\begin{array}{l}\text { Influence of coated implants with TGF- } \beta 1 \text { on the } \\
\text { early bone healing around dental implants }\end{array}$ & Goats & 6 weeks & $\begin{array}{l}\text { Has a negative effect on the incorporation } \\
\text { of oral implants in trabecular bone }\end{array}$ \\
\hline Schouten et al. (2009) & $\begin{array}{l}\text { Titanium implants coated with osteoinductive } \\
\text { growth factor (TGF- } \beta 1)\end{array}$ & Goat & 12 weeks & $\begin{array}{l}\text { Showed substantial improvement of the } \\
\text { osteogenic response }\end{array}$ \\
\hline Lee S.Y. et al. (2010) & $\begin{array}{l}\text { PLGA in combination with basic fibroblast growth } \\
\text { factor (bFGF) coating on an anodized implant } \\
\text { surface }\end{array}$ & Rabbits & 12 weeks & $\begin{array}{l}\text { May possibly improve bone formation near } \\
\text { the implant surface }\end{array}$ \\
\hline Ramazanoglu et al. (2011) & $\begin{array}{l}\text { rhBMP-2 and recombinant human vascular } \\
\text { endothelial growth factor } 165 \text { (rhVEGFI65) coating } \\
\text { implant surfaces }\end{array}$ & Pigs & $\begin{array}{l}1,2, \text { and } \\
4 \text { weeks }\end{array}$ & $\begin{array}{l}\text { Biomimetic CP-coated implant surfaces } \\
\text { with both BMP and VEGF did not improve } \\
\text { BIC but did increase BV density }\end{array}$ \\
\hline Schliephake et al. (2015) & $\begin{array}{l}\text { Effect of coated implant with Recombinant human } \\
\text { vascular endothelial growth factor (rhVEGF) on }\end{array}$ & Rats & $\begin{array}{l}1,4, \text { and } \\
13 \text { weeks }\end{array}$ & Can speed up BIC to a certain extent \\
\hline
\end{tabular}
peri-implant bone formation 
influence of implant surfaces modified with Transforming Growth Factor- $\beta$.

Jiang et al. (2013) found much greater cell feasibility on the surfaces of a roughened or sandblasted implant coated with BMP2 compared to uncoated control surfaces. The same authors concluded that BMP-2 genes are important in accelerating the osteoinductivity around implants. Kim et al. (2014) established that implants coated with BMP-2 could be effective in the stimulation of initial and late osteoblast differentiation. They reported that bone regeneration was considerably higher near the implants coated with BMP-2 compared to near uncoated implants. However, Lee S.W. et al. (2014) noticed that the formation of peri-implant bone formation was superior for the HA and CO group, whereas BMP did not increase periimplant bone formation. Bouyer et al. (2016) evaluated the influence of BMP-2 concentrations with crosslinking levels of EDC10 (ethylene imine linear poly) and EDC30. They reported that EDC30 crosslinking levels have no considerable effect on the volume ratio of the bone. Sun et al. (2012) examined the creation of new bone in peri-implant bone defect by BMP2/7 heterodimer, comparing these BMP2 or BMP7 homodimer. The findings supported the utilization of heterodimers and, afterward, they displayed greater regeneration of the bone. Kim et al. (2015) examined the effects of BMP-2 dose on osseointegration in dogs. They reported that SLA implants coated with BMP-2 were more active in improving osseointegration. Liu et al. (2007) evaluated the influence of BMP-2 and its method of distribution on the osteoconductivity of implants. They noticed that the osteoconductivity of implant surfaces can be adversely modulated by BMP-2 and its method of delivery. Mantripragada and Jayasuriya (2016) applied BMP7 by different delivery methods and examined bone repair. They reported no significant difference among various delivery methods. Hunziker et al. (2012) assessed the influence of mode of delivery of BMP-2 on peri-implant bone formation and found no benefit for any specific delivery method. Xiao et al. (2016) investigated osteogenic function for different surface topographies and found that Ti implants coated with BMP2 genes enhanced bone creation around the implants. Yeo (2014) reported that an oxidized implant surface coated with BMP encouraged bone osseointegration. Huh et al. (2012) investigated the effect of BMP-2 coating on anodized implants in dogs. They observed that coating with BMP-2 increased bone formation and improved implant stability. Becker et al. (2006) found that BMP-2 immobilized by covalent and noncovalent approaches on chromosulfuric acid surface-enhanced implant surfaces appeared to be stable and stimulated direct bone apposition in a concentration-dependent manner. In the femurs of rabbits, Lan et al. (2007) studied the effect of BMP-2 on boneimplant osseointegration and reported that BMP-2 increases the quality and quantity of implant-bone osseointegration. Wikesjö et al. (2008a) observed that BMP-2 adsorbed onto a Ti porous oxide implant surface induced peri-implant bone remodeling. Wikesjö et al. (2008b) assessed local bone formation and osseointegration in monkeys. They found that BMP-2-coated Ti porous oxide implant surfaces improved local bone creation in type IV bone in a dose-dependent manner in non-human primates, leading to considerable osseointegration.
Lan et al. (2006) evaluated the influence of combining rhBMP-2 and recombinant human insulin-like growth factor1 (rhIGF-1) or recombinant human basic fibroblast growth factor (rhbFGF) on osseointegration. They noted that rhBMP2 was able to act synergistically with rhIGF-1 and rhbFGF to enhance osseointegration. According to Xing et al. (2017), the biofunctionalized polyelectrolyte multilayers loaded with IGF1 coated on titanium implant of implant encourages bone consolidation under osteoporotic situations and offers innovative strategies for implant repair in osteoporotic patients. Anitua (2006) found that applying PRGF on the surface of an implant before insertion into the alveolar bone enhanced osseointegration. Park et al. (2006) assessed the bone response around anodized implants coated with fibroblast growth factor-fibronectin (FGFFN) fusion protein in a rabbit tibia model and found that this coating will possibly improve osseointegration. Nikolidakis et al. (2009) studied the influence of transforming growth factor $\beta 1$ (TGF- $\beta 1$ ) on the initial bone healing around dental implants. They reported that a small dose of TGF- $\beta 1$ has an undesirable effect on the incorporation of oral implants in trabecular bone during the early post-implantation healing stage. Schouten et al. (2009) examined the effects of implant design, surface properties, and TGF- $\beta 1$ on peri-implant bone response. They found that adding an electrosprayed CP coating extensively improved bone response. Lee S.Y. et al. (2010) examined the effect of PLGA in combination with basic fibroblast growth factor (bFGF) coating on an anodized implant surface. They suggested that Ti implant coating with PLGA combined with bFGF by electrospraying may possibly improve bone formation near the implant surface. Ramazanoglu et al. (2011) examined whether rhBMP-2 and recombinant human vascular endothelial growth factor I65 (rhVEGFI65) implant surface coating can enhance osseointegration. They found that biomimetic CP coated implant surfaces with both BMP and VEGF did not show improved BIC but did increase BV density. Schliephake et al. (2015) analyzed whether recombinant human vascular endothelial growth factor (rhVEGF) stimulates peri-implant bone formation. They observed that rhVEGF can speed up BIC to a certain extent.

\section{ANTIBACTERIALLY COATED IMPLANT}

Various studies found that the implant surface is prone to infection due to the creation of a surface biofilm and compromised immune capability at the interface of implant and tissue. The protein layer made under physiological conditions, which is responsible for the biocompatibility of the implant, is suitable for bacterial colonization and biofilm formation (Dunne, 2002; Harris and Richards, 2006; Hetrick and Schoenfisch, 2006). Inflammatory lesions affecting the tissue surrounding the implant caused by bacterial infection are known as peri-implant diseases (Zitzmann and Berglundh, 2008). Therefore, some authors attempt functionalization of the implant surface with the aim of preventing biomaterialassociated infections. Such antibacterial approaches are mainly designed to prevent bacterial colonization of the implant 
surface before biofilm formation can occur (Zhao et al., 2009; Campoccia et al., 2013).

Several techniques have been used in order to attach antibiotics and anti-inflammatories to implant surfaces, such as $\mathrm{CP}$ coatings, sol-gel coatings, biodegradable polymer coatings, or loaded nanotubes (Zhao et al., 2009; Chen et al., 2013). According to Bose et al. (2011), potential materials should have the capacity to integrate a bioactive agent chemically or physically, hold it until arrival at the particular target, provide the active agent in an organized way over time, and be gradually degraded. Calcium phosphates and their composites meet all of these criteria. Several studies have incorporated various antibiotics into CP to make the implant antibacterial (Radin et al., 1997; Takechi et al., 1998; Gautier et al., 2001; Ratier et al., 2001; Baro et al., 2002; Zhang and Zhang, 2002; Peter et al., 2005; Oyane et al., 2006; Laurent et al., 2008; Zhang and Kataoka, 2009; Luginbuehl et al., 2010; Altomare et al., 2012; Rajesh et al., 2013; Govindan and Girija, 2014; Fu et al., 2015), for instance, gentamicin (Baro et al., 2002; Laurent et al., 2008; Altomare et al., 2012; Rajesh et al., 2013; Govindan and Girija, 2014), tobramycin (Brohede et al., 2009), cephalothin (Wang et al., 2003), amoxicillin (Brohede et al., 2009; Merdji et al., 2012), tetracycline (Ratier et al., 2001; Luginbuehl et al., 2010), vancomycin (Radin et al., 1997; Gautier et al., 2001), zoledronate (Peter et al., 2005), streptomycin (Fu et al., 2015), and flomoxef sodium (Takechi et al., 1998). However, using an antibacterial agent based on antibiotics raises the concern that antibiotics-resistant bacteria will develop.

Integrating antibacterial ions and NPs into the calcium phosphates is a potentially attractive alternative method. Due to the antibacterial properties of silver, a number of studies have incorporated it in calcium phosphates (ChimutengwendeGordon et al., 2014; Massa et al., 2014; Yan et al., 2014; Xie et al., 2015; Yan et al., 2015). Silver shows low toxicity in the human body. Although the human body has no biological use for silver, the toxicity of silver is low, and when applied topically, swallowed, inhaled, or injected, it will collect irreversibly in the body, mainly in the skin. ZnO NPs are another type of antibacterial ion, and these NPs can be integrated into calcium phosphates as an alternative to silver (Grenho et al., 2015; Huang et al., 2015). However, $\mathrm{ZnO}$ NPs have apparent toxicological influences, as reported by Morejón-Alonso et al. (2007).

Several approaches have been used for the placing of antibiotics in the calcium phosphate, including in situ deposition (Altomare et al., 2012), mixing powders throughout the production of scaffolds and pressed coatings (Shadanbaz and Dias, 2012), absorption in microspheres during CP synthesis (Sivakumar and Rao, 2002), covalent protein immobilization in microspheres (Belcarz et al., 2009), co-precipitation (Tadic et al., 2004), dip-coating (Tadic et al., 2004), etc. The transporters comprise, among others, chitosan (Sivakumar and Rao, 2002) and gelatin (Baro et al., 2002; Sivakumar et al., 2002; Tadic et al., 2004; Belcarz et al., 2009; Altomare et al., 2012). Calcium phosphate coatings have mostly been applied by plasma spray technology. However, because of the extremely high processing temperatures involved, this procedure cannot incorporate antibiotics during the coating process (Goodman et al., 2013). Therefore, a post-treatment has been employed, typically physical absorption, to incorporate antibiotics into such coatings (Goodman et al., 2013). Previous studies used an immersion technique to incorporate a diversity of antibiotics into biomimetically prepared carbonated HA coatings. They reported that some antibiotics were well integrated, depending on their chemical structure. Furthermore, they exhibited that the release rate varied between antibiotics, reaching only 1-day release for gentamicin (Stigter et al., 2002, 2004).

Antimicrobial peptides have recently been introduced to treat septic infection owing to their capability to stimulate innate immune responses and for the difficulty microorganisms have in developing resistance toward them. Controlling the surface of an implant by generating an interface composed of peptides may thus open up new potentials to cover the implant site and tailor it to an appropriate bioactivity (Yucesoy et al., 2015). Yazici et al. (2016) designed bifunctional peptides that were characterized both in solution and on the $\mathrm{Ti}$ surface to determine their concomitant solid-binding property and antimicrobial efficacy against three bacteria, Streptococcus mutans, S. epidermidis, and E. coli. The same authors exposed that surfaces modified with both of two chimeric peptides had a considerable reduction in bacterial adhesion against all three bacteria compared to bare titanium. Doxycycline, an antibiotic that belongs to the group of tetracyclines, is an attractive candidate. It is effective against both gram-negative and gram-positive aerobic and anaerobic pathogens (Cunha et al., 1982). Surfaces coated with doxycycline by means of cathodic polarization have been demonstrated to exhibit antibacterial properties and to promote bone formation (Walter et al., 2014; Xing et al., 2015). The topic of antibioticsincorporated calcium phosphates has been studied in detail in other reports (van de Belt et al., 2001; Lin et al., 2015).

\section{DENTAL IMPLANT BASED ON THE FUNCTIONALLY GRADED CONCEPT}

Functionally graded materials (FGMs) display either a gradient in chemical composition or in structure within them. They involve a number of constituents that reveal a compositional gradient across the thickness of the material. Subsequently, FGMs permit properties to be obtained that cannot be accomplished by each constituent material. Teeth and bones are examples of natural materials of this type and are the basis for the development of the FGM idea, with its origin concerning their sophisticated properties (Pompe et al., 2003; He and Swain, 2009; Senan and Madfa, 2017). The investigation of the remarkable properties of natural and novel artificial hard tissues has the potential to give insight into biomimetic material design and the development of novel functional materials (Huang et al., 2007). Continuous alterations of tissue composition, as well as of structure, have been widely identified in biology. For instance, the density of bone changes from outside (stiff cortical bone) to inside (cancellous bone) and gives rise to the notion that functional gradation has been used by biological adaptation (Hedia $\mathrm{H}$., 2005, Hedia H.S., 2005; Hung et al., 2013). In the body, this functional gradation has been used and has been accepted as a method for implant alteration in previous years. Thus, a 
fabricated implant must reveal a similar gradation to that of the natural bone. This has been applied in the development of dental implants based on the functionally graded concept, with the proposition of adding porosity gradients, adding surface layer coatings, and forming composite materials made fundamentally of ceramics (e.g., HA) and metal that should promote the implant to act comparably with respect to biocompatibility and stress distribution (Hedia H.S., 2005; Lin et al., 2009; Hung et al., 2013).

For functionally graded dental implants, a cylindrical shape was designed, with the structure changing axially. The upper part necessarily has more strength so as to transmit stress down to the inferior parts, which are implanted inside the cancellous bone, where more biocompatible materials are required (Watari et al., 2004).

Some studies added $\mathrm{CP}$ coatings to $\mathrm{Ti}$ and/or zirconia that could be prepared to a functionally graded scheme to offer a gradient of bioactivity and good mechanical strength (Bishop et al., 1993; Takahashi, 1993; Matsuno et al., 1996, 2000; Hisbergues et al., 2009). Matsuno et al. (1998) showed the ability to produce a laminated HA/PSZ composite material through sintering. Later on, Guo et al. (2003) used spark plasma sintering to prepare functionally graded HA/yttria stabilized tetragonal zirconia (Y-TZP) composites. They reported a development in the mechanical properties of the functionally graded (FG) HA/Y-TZP composites when compared with pure HA ceramics. Chu et al. (2003) successfully fabricated asymmetrical HA/Ti FGM by a hot pressing method. They then analyzed the stress in the sintered HA/Ti FGM composites by x-ray testing, and the results were consonant with the calculated values. The gradual rise of the HA contents from the core region toward the coating causes relaxation of thermal stresses and enhances the mechanical properties of the coating layer. Comparable findings were obtained by Watari et al. (2004). Using the plasma spray method, three layered functionally graded HA/Ti-6Al-4V coatings were fabricated optimally by Khor et al. (2003). This composite coating showed improved microstructure, microhardness, porosity, density, and Young's modulus. Additionally, no sharp interface between the different layers was detected under the electron microscope. Furthermore, Yamada et al. (2001) fabricated HA/glass FG coatings on a Ti substrate using the Cullet method. The gradient increase in glass contents from the core region to the outer surface resulted in improved bonding of the coating to the Ti substrate. Hedia and Mahmoud (2004) found that the maximum stress in the bone for optimally designed HA/Ti FGM decreased by $22 \%$ in comparison to a monolithic Ti implant. Using 3D FEM, Yang and Xiang (2007) conducted a comprehensive parametric study of the biomechanical behavior of an FG dental implant, taking in consideration the interaction of the implant and the surrounding bone under static conditions as well as under normal occlusal forces. The maximum stress difference at the FG implant-bone interfaces was reduced significantly. Moreover, Wang et al. (2007) considered the thermal variation in daily oral activities in their investigation of the thermomechanical behavior of HA/Ti FGM dental implants using FEM. They found that the FGM with a gradually changing HA concentration behaved almost equally well, while Ti caused much higher von Mises stress. Roy et al. (2011) applied the laser engineering net shaping process to place TCP on commercially pure $\mathrm{Ti}$, and a compositionally graded nature was achieved. Marković et al. (2015) fabricated nanostructured FG via sintering. Farnoush et al. (2015) used electrophoretic deposition to create an FG $\mathrm{HA}-\mathrm{TiO}_{2}$ nanostructured composite coating on a Ti$6 \mathrm{Al}-4 \mathrm{~V}$ substrate. Another study by Kumar and Wang (2002) calculated the hardness and modulus of elasticity of FG HA/Ti and HA/ $\beta-T C P / T i$ coatings. Cattini et al. (2014) utilized the suspension plasma spraying technique to produce different bioactive glass/HA coatings.

Porosity gradient has been studied as another way to fabricate an FG implant structure (Hunziker et al., 2012). Becker and Bolton (1997) suggested using porous FGM Ti alloys for dental implants. By controlling the pore size and distribution, the mechanical properties of porous dental implants can be changed and optimized (Mehrali et al., 2013). A graded porosity from the core to the surface layer is offered for implant fabrication. This will lead to a reduction in the stiffness difference at the implant/bone interface (Traini et al., 2008), thereby reducing the stress shielding-induced bone resorption.

A variety of methods have been established in recent years to produce dental implants that mimic the behavior of natural tooth under function (Tolochko et al., 2002). Lifland et al. (1993) used electron-discharge compaction to create a porous surface on a commercially available dental implant. Kutty and Bhaduri (2004) utilized one-step microwave processing to make graded-porosity dental implants. A number of scientists have developed additive manufacturing methods such as selective laser melting (SLM), selective laser sintering (SLS), and electron beam melting (EBM) (Hrabe et al., 2011; Mangano et al., 2012). These methods are applied for the fabrication of porous structures with different unit cells (Ahmadi et al., 2014) and high resolution (i.e., small cell sizes) (Cheng et al., 2014), based on building up a three-dimensional structure from a computer-aided design model (Ryan et al., 2006).

Tolochko et al. (2002) used Ti powders to create dental implants with a compact core and irregular porous shell via SLM for the solid core and SLS for the porous surface. Traini et al. (2008) used a laser sintering procedure to fabricate implants, integrating graduated porosity from the inner core of the structure to the outer surface using Ti alloy (Ti-6Al-4V) powders. On the other hand, Mangano et al. (2009) recommended using a fully porous structure to make it possible to construct implants with irregular and narrow intercommunicating crevices and shallow depressions using Ti-6Al-4V powders. Murr et al. (2010) used EBM to create open cellular foams with solid and hollow cell wall structures. Li et al. (2010) developed Ti-6Al-4V implants with versatile porosity via EBM. They found that the compressive properties of implants are variable with pore architecture and can be equivalent to those of natural bone. Laoui et al. (2006) found that by utilizing laser gas nitriding using a CW Nd:YAG laser, the coating layer formed was capable of resisting more stress cycles without fracturing. However, at the junction area of the shell and core of the implant, stress concentrations could arise due to the rapidly changing mechanical properties, as reported by Hao et al. (2003). Therefore, Cook et al. (1988) recommended a post-sintering heat treatment to minimize the residual stresses. They reported that the fatigue strength of $\mathrm{Ti}$ alloy improved 
by about $15 \%$. Nevertheless, producing FG structures could be suitable for preventing the concentration of stress between the interface layers (Joshi et al., 2013).

The concept of constructing FG structures in porous materials by changing the structure of the lattice has also been investigated (van Grunsven et al., 2014). Witek et al. (2012) used laser sintering to make dental implants with a porous layer and compared them with a sandblasted-acid etched implant. They examined the BIC and removal torque and found that porous implants created by the sintering process showed better biomechanical properties and biocompatibility. Bandyopadhyay et al. (2010) proposed laser-engineered net shaping to make porous structures from Ti-6Al-4V alloy that can be tailored to mimic human cortical bone. To produce porous Ti/HA composites, Nomura et al. (2010) suggested an infiltration method in a vacuum with sintering.

Some authors designed FG scaffolds based on pore-graded $\mathrm{CP}$ to meet both biological and mechanical requirements (Vaz et al., 1999; Wang et al., 1999). Werner et al. (2002) established that bending strength was approximately $50 \%$ higher for a poregraded CP scaffold than that of an HA scaffold.

FG coatings can also help in antibacterial activity. Manjubala et al. (2000) fabricated an FG coating in which Ag was added onto coralline HA. Manjubala and Kumar (2000) created an FG CP scaffold based on $\mathrm{TiO}_{2}, \mathrm{HA}$, TCP, and $\mathrm{Ag}_{2} \mathrm{O}$ to increase the scaffold's mechanical stability and antibacterial activity. Bai et al. (2010) emplaced a series of FG coatings based on HA. The authors incorporated various percentages of silver, utilizing ion beam-assisted deposition.

FG CP can also be applied for simulating interfaces ( $\mathrm{Li}$ et al., 2009; Samavedi et al., 2011; Sartoretto et al., 2017) or bonecartilage (Erisken et al., 2008). Li et al. (2009) made a gradient in mineral content for the simulation of a tendon-bone interface in which stiffness changed, as did the activity of preosteoblast cells. To mimic the bone-cartilage interface, Erisken and collaborators (Erisken et al., 2008) utilized twin-screw extrusion to create a graded scaffold made of PCL/ $\beta$-TCP. Using this hybrid method, they were able to tailor a graded scaffold with a $\beta$-TCP content of $0-15 \mathrm{wt} . \%$. They noticed markers akin to the type of variations observed in a typical bone-cartilage interface after four weeks of seeding cells into the scaffold.

Many authors have studied the biological interaction of dental implants with porous surface geometry. Mangano et al. (2012) applied a laser sintering procedure to create implants with interconnected pores and irregular crevices. They reported that success was 95\% 1 year post-operation. Teixeira et al. (2012) used different industrial methods and reported a good range of bone ingrowth in porous Ti implant. Hollander et al. (2006) demonstrated that osteoblast cells entirely roofed the porous structure. Bandyopadhyay et al. (2010) reported that the

\section{REFERENCES}

Abraham, C. M. (2014). A brief historical perspective on dental implants, their surface coatings and treatments. Open Dent J. 8, 50-55. doi: 10.2174/ 1874210601408010050

Abron, A., Hopfensperger, M., Thompson, J., and Cooper, L. F. (2001). Evaluation of a predictive model for implant surface concentration of calcium ions increased proportionately with the increasing porosity percentage after 16 weeks. Laoui et al. (2006) found clear bone growth into the porous structure within a porous surface layer. They also noticed no signs of inflammation at the interface. Tolochko et al. (2002) established that the porous implant they tested was firmly joined into the alveolar ridge with a maximum gap width of $200-300 \mu \mathrm{m}$ between the bone and the implant.

\section{CONCLUSION AND FUTURE PERSPECTIVES}

This review has studied the dental implant, giving its possible disadvantages and making suggestions for its improvement. Several design parameters have been assessed, and many designs have also been examined.

Biomimetic surface modification and bioinspired functionally graded structures can address the challenges currently faced by existing implants. Surface functionalization of dental implants via a biomimetic process showed improvement in osseointegration and enhancement in bone regeneration. Furthermore, the bioinspired functionally graded structure can be used to fabricate dental implants. These dental implants with similar biological and mechanical properties to those of natural tooth and bone might potentially result in better long-term clinical performance under function.

More research on implant structure, design parameters, surface treatment technologies, and analysis techniques are still required to improve outcomes. Therefore, further studies are needed to assess the potential of progressive manufacturing approaches to optimize the surface functionalization of implants and enhance their graduation structure.

\section{DATA AVAILABILITY STATEMENT}

The datasets generated for this study are available on request to the corresponding author.

\section{AUTHOR CONTRIBUTIONS}

AMa contributed to the research concept, supervision, literature collection, technical steps, writing the original draft, and reviewing and editing the final manuscript. SA-Z contributed by searching, literature collection, and writing the original draft. $\mathrm{AMu}, \mathrm{MA}$, and $\mathrm{OH}$ contributed to the research concept, literature collection, and writing the original draft. X-GY contributed to the research concept and writing the original draft.

topography effects on early osseointegration in the rat tibia model. J. Prosthet. Dent. 85, 40-46. doi: 10.1067/mpr.2001.11 2415

ADA Council on Scientific Affairs (2003). Titanium applications in dentistry. J. Am. Dent. Assoc. 134, 347-349. doi: 10.14219/jada.archive.2003.0165

Ágata de Sena, L., Calixto, de Andrade, M., Malta Rossi, A., and de Almeida Soares, G. (2002). Hydroxyapatite deposition by electrophoresis on titanium 
sheets with different surface finishing. J. Biomed. Mater. Res. 60, 1-7. doi: $10.1002 / j b m .10003$

Ahmadi, S., Campoli, G., Yavari, S. A., Sajadi, B., Wauthlé, R., Schrooten, J., et al. (2014). Mechanical behavior of regular open-cell porous biomaterials made of diamond lattice unit cells. J. Mech. Behav. Biomed. Mater. 34, 106-115. doi: 10.1016/j.jmbbm.2014.02.003

Aita, H., Hori, N., Takeuchi, M., Suzuki, T., Yamada, M., Anpo, M., et al. (2009). The effect of ultraviolet functionalization of titanium on integration with bone. Biomaterials 30, 1015-1025. doi: 10.1016/j.biomaterials.2008. 11.004

Albrektsson, T., and Wennerberg, A. (2004). Oral implant surfaces: Part 1-review focusing on topographic and chemical properties of different surfaces and in vivo responses to them. Int. J. Prosthodont. 17, 536-543.

Alghamdi, H. S., van Oirschot, B. A., Bosco, R., van den Beucken, J. J., Aldosari, A. A., Anil, S., et al. (2013). Biological response to titanium implants coated with nanocrystals calcium phosphate or type 1 collagen in a dog model. Clin. Oral. Implants. Res. 24, 475-483. doi: 10.1111/j.1600-0501.2011. 02409.x

Al-Nawas, B., and Wagner, W. (2017). "7.19 materials in dental implantology," in Comprehensive Biomaterials II, ed. P. Ducheyne (Oxford: Elsevier), 341-377. doi: 10.1016/B978-0-12-803581-8.10235-8

Altomare, L., Visai, L., Bloise, N., Arciola, C. R., Ulivi, L., Candiani, G., et al. (2012), Electrochemically deposited gentamicin-loaded calcium phosphate coatings for bone tissue integration. Int. J. Artif. Organs 35, 876-883. doi: 10.5301/ijao. 5000162

Anitua, E. A. (2006). Enhancement of osseointegration by generating a dynamic implant surface. J. Oral. Implantol. 32, 72-76. doi: 10.1563/ 736.1

Anselme, K., Bigerelle, M., Noel, B., Iost, A., and Hardouin, P. (2002). Effect of grooved titanium substratum on human osteoblastic cell growth. J. Biomed. Mater. Res. 60, 529-540. doi: 10.1002/jbm. 10101

Ao, H.-Y., Xie, Y.-T., Yang, S.-B., Wu, X.-D., Li, K., Zheng, X.-B., et al. (2016). Covalently immobilised type I collagen facilitates osteoconduction and osseointegration of titanium coated implants. J. Orthop. Translat. 5, 16-25. doi: 10.1016/j.jot.2015.08.005

Aoki, H. (1991). Science and Medical Applications of Hydroxyapatite. Tokyo: Japanese Association of Apatite Science, 123-134.

Aparicio, C., Gil, F. J., Fonseca, C., Barbosa, M., and Planell, J. A. (2003). Corrosion behaviour of commercially pure titanium shot blasted with different materials and sizes of shot particles for dental implant applications. Biomaterials 24, 263-273. doi: 10.1016/s0142-9612(02)00314-9

Astrand, P., Engquist, B., Dahlgren, S., Engquist, E., Feldmann, H., and Grondahl, K. (1999). Astra Tech and Branemark System implants: a prospective 5-year comparative study. Results after one year. Clin. Implant Dent. Relat. Res. 1, 17-26. doi: 10.1111/j.1708-8208.1999.tb00087.x

Azad, A.-M., Hershey, R., Ali, S., and Goel, V. (2010). Bactericidal efficacy of electrospun pure and Fe-doped titania nanofibers. J. Mater. Res. 25, 1761-1770. doi: $10.1557 /$ jmr.2010.0237

Azadmanjiri, J., Wang, P.-Y., Pingle, H., Kingshott, P., Wang, J., Srivastava, V. K., et al. (2016). Enhanced attachment of human mesenchymal stem cells on nanograined titania surfaces. RSC Adv. 6, 55825-55833. doi: 10.1039/ c6ra10289a

Bae, E.-B., Yoo, J.-H., Jeong, S.-I., Kim, M.-S., Lim, Y.-M., Ahn, J.-J., et al. (2018). Effect of Titanium implants coated with radiation-crosslinked collagen on stability and osseointegration in rat tibia. Materials 11:2520. doi: 10.3390/ ma11122520

Baeuerle, D. (2000). Laser Processing And Chemistry. Berlin: Springer, doi: 10.1007/ 978-3-662-04074-4_1

Bai, X., More, K., Rouleau, C. M., and Rabiei, A. (2010). Functionally graded hydroxyapatite coatings doped with antibacterial components. Acta Biomater. 6, 2264-2273. doi: 10.1016/j.actbio.2009.12.002

Baier, R. E., and Meyer, A. E. (1988). Implant surface preparation. Int. J. Oral Maxillofac. Implants 3, 9-20.

Bandyopadhyay, A., Espana, F., Balla, V. K., Bose, S., Ohgami, Y., and Davies, N. M. (2010). Influence of porosity on mechanical properties and in vivo response of Ti6Al4V implants. Acta Biomater. 6, 1640-1648. doi: 10.1016/j.actbio.2009. 11.011

Barfeie, A., Wilson, J., and Rees, J. (2015). Implant surface characteristics and their effect on osseointegration. Br. Dent. J. 2015:E9.
Baro, M., Sanchez, E., Delgado, A., Perera, A., and Evora, C. (2002). In vitro-in vivo characterization of gentamicin bone implants. J. Control Rel. 83, 353-364. doi: 10.1016/s0168-3659(02)00179-7

Barrere, F., Layrolle, P., Van Blitterswijk, C., and De Groot, K. (1999). Biomimetic calcium phosphate coatings on Ti6Al4V: a crystal growth study of octacalcium phosphate and inhibition by Mg2+ and HCO3-. Bone 25, 107S-111S. doi: 10.1016/s8756-3282(99)00145-3

Barrere, F., Layrolle, P., Van Blitterswijk, C. A., and De Groot, K. (2001). Biomimetic coatings on titanium: a crystal growth study of octacalcium phosphate. J. Mater. Sci. Mater. Med. 12, 529-534.

Barrere, F., Snel, M. M., van Blitterswijk, C. A., de Groot, K., and Layrolle, P. (2004). Nano-scale study of the nucleation and growth of calcium phosphate coating on titanium implants. Biomaterials 25, 2901-2910. doi: 10.1016/j.biomaterials. 2003.09.063

Barrere, F., Van Der Valk, C., Meijer, G., Dalmeijer, R., De Groot, K., and Layrolle, P. (2003). Osteointegration of biomimetic apatite coating applied onto dense and porous metal implants in femurs of goats. J. Biomed. Mater. Res. B 67, 655-665. doi: 10.1002/jbm.b.10057

Barros, R. R., Novaes, A. B. Jr., Papalexiou, V., Souza, S. L., Taba, M. Jr., Palioto, D. B., et al. (2009). Effect of biofunctionalized implant surface on osseointegration: a histomorphometric study in dogs. Braz. Dent. J. 20, 91-98. doi: 10.1590/s0103-64402009000200001

Becker, B. S., and Bolton, J. D. (1997). Corrosion behaviour and mechanical properties of functionally gradient materials developed for possible hard-tissue applications. J. Mater. Sci. Mater. Med. 8, 793-797.

Becker, J., Kirsch, A., Schwarz, F., Chatzinikolaidou, M., Rothamel, D., Lekovic, V., et al. (2006). Bone apposition to titanium implants biocoated with recombinant human bone morphogenetic protein-2 (rhBMP-2). A pilot study in dogs. Clin. Oral. Investig. 10, 217-224. doi: 10.1007/s00784-006-0049-0

Belcarz, A., Ginalska, G., Zalewska, J., Rzeski, W., Ślósarczyk, A., Kowalczuk, D., et al. (2009). Covalent coating of hydroxyapatite by keratin stabilizes gentamicin release. J. Biomed. Mater. Res. B 89, 102-113. doi: 10.1002/jbm.b.31192

Bhardwaj, G., and Webster, T. (2017). Reduced bacterial growth and increased osteoblast proliferation on titanium with a nanophase $\mathrm{TiO} 2$ surface treatment. Int. J. Nanomed. 12, 363-369. doi: 10.2147/IJN.S116105

Bigerelle, M., Anselme, K., Noel, B., Ruderman, I., Hardouin, P., and Iost, A. (2002). Improvement in the morphology of Ti-based surfaces: a new process to increase in vitro human osteoblast response. Biomaterials 23, 1563-1577. doi: 10.1016/s0142-9612(01)00271-X

Bigi, A., Boanini, E., Bracci, B., Facchini, A., Panzavolta, S., Segatti, F., et al. (2005). Nanocrystalline hydroxyapatite coatings on titanium: a new fast biomimetic method. Biomaterials 26, 4085-4089. doi: 10.1016/j.biomaterials.2004.10.034

Bishop, A., Lin, C. Y., Navaratnam, M., Rawlings, R. D., and McShane, H. B. (1993). A functionally gradient material produced by a powder metallurgical process. J. Mater. Sci. Lett. 12, 1516-1518. doi: 10.1007/BF00277083

Block, M. S., Finger, I. M., Fontenot, M. G., and Kent, J. N. (1989). Loaded hydroxyapatite-coated and grit-blasted titanium implants in dog. Int. J. Oral Maxillofac. Implants 4, 219-225.

Block, M. S., Kent, J. N., and Kay, J. F. (1987). Evaluation of hydroxylapatitecoated titanium dental implants in dogs. J. Oral. Maxillofac. Surg. 45, 601-607. doi: 10.1016/0278-2391(87)90270-9

Bonfante, E. A., Granato, R., Marin, C., Jimbo, R., Giro, G., Suzuki, M., et al. (2013). Biomechanical testing of microblasted, acid-etched/microblasted, anodized, and discrete crystalline deposition surfaces: an experimental study in beagle dogs. Int. J. Oral Maxillofac. Implants 28, 136-142. doi: 10.11607/jomi.2331

Bornstein, M. M., Valderrama, P., Jones, A. A., Wilson, T. G., Seibl, R., and Cochran, D. L. (2008). Bone apposition around two different sandblasted and acid-etched titanium implant surfaces: a histomorphometric study in canine mandibles. Clin. Oral Implants Res. 19, 233-241. doi: 10.1111/j.1600-0501.2007. 01473.x

Bose, S., and Tarafder, S. (2012). Calcium phosphate ceramic systems in growth factor and drug delivery for bone Tissue Eng: a review. Acta Biomater. 8, 1401-1421. doi: 10.1016/j.msec.2016.09.074

Bose, S., Tarafder, S., Edgington, J., and Bandyopadhyay, A. (2011). Calcium phosphate ceramics in drug delivery. JOM 63, 93-98. doi: 10.1007/s11837-0110065-7

Botos, S., Yousef, H., Zweig, B., Flinton, R., and Weiner, S. (2011). The effects of laser microtexturing of the dental implant collar on crestal bone levels and peri-implant health. Int. J. Oral Maxillofac. Implants 26, 492-498. 
Bouyer, M., Guillot, R., Lavaud, J., Plettinx, C., Olivier, C., Curry, V., et al. (2016). Surface delivery of tunable doses of BMP-2 from an adaptable polymeric scaffold induces volumetric bone regeneration. Biomaterials 104, 168-181. doi: 10.1016/j.biomaterials.2016.06.001

Boyan, B. D., Lossdorfer, S., Wang, L., Zhao, G., Lohmann, C. H., Cochran, D. L., et al. (2003). Osteoblasts generate an osteogenic microenvironment when grown on surfaces with rough microtopographies. Eur. Cell Mater. 6, 22-27. doi: 10.22203/ecm.v006a03

Brammer, K. S., Frandsen, C. J., and Jin, S. (2012). TiO2 nanotubes for bone regeneration. Trends Biotechnol. 30, 315-322. doi: 10.1016/j.tibtech.2012. 02.005

Brammer, K. S., Oh, S., Frandsen, C. J., Varghese, S., and Jin, S. (2010). Nanotube surface triggers increased chondrocyte extracellular matrix production. Mater. Sci. Eng. C 30, 518-525. doi: 10.1016/j.msec.2010.01.013

Brohede, U., Forsgren, J., Roos, S., Mihranyan, A., Engqvist, H., and Strømme, M. (2009). Multifunctional implant coatings providing possibilities for fast antibiotics loading with subsequent slow release. J. Mater. Sci. Mater. Med. 20, 1859-1867. doi: 10.1007/s10856-009-3749-6

Browne, M., and Gregson, P. J. (2000). Effect of mechanical surface pretreatment on metal ion release. Biomaterials 21, 385-392. doi: 10.1016/s0142-9612(99) 00200-8

Bruschi, M., Steinmller-Nethl, D., Goriwoda, W., and Rasse, M. (2015). Composition and modifications of dental implant surfaces. J. Oral Implants 2015:527426. doi: 10.1155/2015/527426

Buchanan, R. A., Lee, I. S., and Williams, J. M. (1990). Surface modification of biomaterials through noble metal ion implantation. J. Biomed. Mater. Res. 24, 309-318. doi: 10.1002/jbm.820240304

Buser, D., Broggini, N., Wieland, M., Schenk, R., Denzer, A., Cochran, D. L., et al. (2004). Enhanced bone apposition to a chemically modified SLA titanium surface. J. Dent. Res. 83, 529-533. doi: 10.1177/154405910408300704

Buser, D., Janner, S. F., Wittneben, J. G., Bragger, U., Ramseier, C. A., and Salvi, G. E. (2012). 10-year survival and success rates of 511 titanium implants with a sandblasted and acid-etched surface: a retrospective study in 303 partially edentulous patients. Clin. Implant. Dent. Relat. Res. 14, 839-851. doi: 10.1111/j. 1708-8208.2012.00456.x

Buser, D., Schenk, R. K., Steinemann, S., Fiorellini, J. P., Fox, C. H., and Stich, H. (1991). Influence of surface characteristics on bone integration of titanium implants. A histomorphometric study in miniature pigs. J. Biomed. Mater. Res. 25, 889-902. doi: 10.1002/jbm.820250708

Calvo-Guirado, J., Ortiz-Ruiz, A., Negri, B., López-Marí, L., Rodriguez-Barba, C., and Schlottig, F. (2010). Histological and histomorphometric evaluation of immediate implant placement on a dog model with a new implant surface treatment. Clin. Oral Implants Res. 21, 308-315. doi: 10.1111/j.1600-0501.2009. 01841.x

Calvo-Guirado, J. L., Satorres-Nieto, M., Aguilar-Salvatierra, A., Delgado-Ruiz, R. A., de Val, J. E. M.-S., Gargallo-Albiol, J., et al. (2015). Influence of surface treatment on osseointegration of dental implants: histological, histomorphometric and radiological analysis in vivo. Clin. Oral Investig. 19, 509-517. doi: 10.1007/s00784-014-1241-2

Campoccia, D., Montanaro, L., and Arciola, C. R. (2013). A review of the biomaterials technologies for infection-resistant surfaces. Biomaterials 34, 8533-8554. doi: 10.1016/j.biomaterials.2013.07.089

Cattini, A., Bellucci, D., Sola, A., Pawłowski, L., and Cannillo, V. (2014). Microstructural design of functionally graded coatings composed of suspension plasma sprayed hydroxyapatite and bioactive glass. J. Biomed. Mater. Res. B 102, 551-560. doi: 10.1002/jbm.b.33034

Cervino, G., Fiorillo, L., Iannello, G., Santonocito, D., Risitano, G., and Cicciù, M. (2019). Sandblasted and acid etched titanium dental implant surfaces systematic review and confocal microscopy evaluation. Materials 12:1763. doi: 10.3390/ ma12111763

Chaturvedi, T. (2009). An overview of the corrosion aspect of dental implants (titanium and its alloys). Indian J. Dent. Res. 20:91. doi: 10.4103/0970-9290. 49068

Chen, X., Li, Y., and Aparicio, C. (2013). Biofunctional Coatings for Dental Implants.Thin Films and Coatings in Biology. Berlin: Springer, 105-143.

Cheng, A., Humayun, A., Cohen, D. J., Boyan, B. D., and Schwartz, Z. (2014). Additively manufactured $3 \mathrm{D}$ porous Ti-6Al-4V constructs mimic trabecular bone structure and regulate osteoblast proliferation, differentiation and local factor production in a porosity and surface roughness dependent manner. Biofabrication 6:045007. doi: 10.1088/1758-5082/6/4/045007

Chia, H. N., and Wu, B. M. (2015). Recent advances in 3D printing of biomaterials. J. Biol. Eng. 9:4. doi: 10.1186/s13036-015-0001-4

Chimutengwende-Gordon, M., Pendegrass, C., Bayston, R., and Blunn, G. (2014). Preventing infection of osseointegrated transcutaneous implants: Incorporation of silver into preconditioned fibronectin-functionalized hydroxyapatite coatings suppresses Staphylococcus aureus colonization while promoting viable fibroblast growth in vitro. Biointerphases 9:031010. doi: 10.1116/1.4889977

Chu, C., Zhu, J., Yin, Z., and Lin, P. (2003). Optimal design and fabrication of hydroxyapatite-Ti asymmetrical functionally graded biomaterial. Mater. Sci. Eng. A 348, 244-250. doi: 10.1016/s0921-5093(02)00738-4

Cicciù, M., Cervino, G., Herford, A., Famà, F., Bramanti, E., Fiorillo, L., et al. (2018). Facial bone reconstruction using both marine or non-marine bone substitutes: Evaluation of current outcomes in a systematic literature review. Mar. Drugs 16:27. doi: 10.3390/md16010027

Cochran, D. L., Jackson, J. M., Bernard, J. P., ten Bruggenkate, C. M., Buser, D., Taylor, T. D., et al. (2011). A 5-year prospective multicenter study of early loaded titanium implants with a sandblasted and acid-etched surface. Int. J. Oral Maxillofac. Implants 26, 1324-1332.

Cochran, D. L., Nummikoski, P. V., Higginbottom, F. L., Hermann, J. S., Makins, S. R., and Buser, D. (1996). Evaluation of an endosseous titanium implant with a sandblasted and acid-etched surface in the canine mandible: radiographic results. Clin. Oral Implants Res. 7, 240-252. doi: 10.1034/j.1600-0501.1996. 070306.x

Coelho, P. G., Granjeiro, J. M., Romanos, G. E., Suzuki, M., Silva, N. R., Cardaropoli, G., et al. (2009). Basic research methods and current trends of dental implant surfaces. J. Biomed. Mater. Res. B 88, 579-596. doi: 10.1002/jbm. b. 31264

Coelho, P. G., Jimbo, R., Tovar, N., and Bonfante, E. A. (2015). Osseointegration: hierarchical designing encompassing the macrometer, micrometer, and nanometer length scales. Dent. Mater. 2015, 37-52. doi: 10.1016/j.dental.2014. 10.007

Cook, S. D., Thongpreda, N., Anderson, R. C., and Haddad, R. J. Jr. (1988). The effect of post-sintering heat treatments on the fatigue properties of porous coated Ti-6Al-4V alloy. J. Biomed. Mater. Res. 22, 287-302. doi: 10.1002/jbm. 820220404

Cooper, L. F., Zhou, Y., Takebe, J., Guo, J., Abron, A., Holmen, A., et al. (2006). Fluoride modification effects on osteoblast behavior and bone formation at TiO2 grit-blasted c.p. titanium endosseous implants. Biomaterials 27, 926-936. doi: 10.1016/j.biomaterials.2005.07.009

Cunha, B. A., Sibley, C. M., and Ristuccia, A. M. (1982). Doxycycline. Ther. Drug Monit. 4, 115-135.

Dalby, M. J., Gadegaard, N., and Oreffo, R. O. (2014). Harnessing nanotopography and integrin-matrix interactions to influence stem cell fate. Nat. Mater. 13:558 doi: $10.1038 /$ nmat3980

Das, K., Bose, S., and Bandyopadhyay, A. (2009). TiO2 nanotubes on Ti: Influence of nanoscale morphology on bone cell-materials interaction. J. Biomed. Mater. Res. A 90, 225-237. doi: 10.1002/jbm.a.32088

Das, S., Gurav, S., Soni, V., Ingle, A., Mohanty, B. S., Chaudhari, P., et al. (2018). Osteogenic nanofibrous coated titanium implant results in enhanced osseointegration: in vivo preliminary study in a rabbit model. J. Tissue Eng. Regen. Med. 15, 231-247. doi: 10.1007/s13770-017-0106-6

De Bruyn, H., Raes, F., Cooper, L. F., Reside, G., Garriga, J. S., Tarrida, L. G., et al. (2013). Three-years clinical outcome of immediate provisionalization of single Osseospeed() implants in extraction sockets and healed ridges. Clin. Oral. Implants Res. 24, 217-223. doi: 10.1111/j.1600-0501.2012.02449.x

De Groot, K., Geesink, R., Klein, C. P., and Serekian, P. (1987). Plasma sprayed coatings of hydroxylapatite. J. Biomed. Mater. Res. 21, 1375-1381. doi: 10.1002/ jbm.820211203

de Jonge, L. T., Leeuwenburgh, S. C., Wolke, J. G., and Jansen, J. A. (2008). Organicinorganic surface modifications for titanium implant surfaces. Pharm. Res. 25, 2357-2369. doi: 10.1007/s11095-008-9617-9610

Degidi, M., Piattelli, A., Gehrke, P., and Carinci, F. (2006). Clinical outcome of 802 immediately loaded 2-stage submerged implants with a new grit-blasted and acid-etched surface: 12-month follow-up. Int. J. Oral Maxillofac. Implants 21, 763-768. 
Del Fabbro, M., Taschieri, S., Canciani, E., Addis, A., Musto, F., Weinstein, R., et al. (2017). Osseointegration of titanium implants with different rough surfaces: A histologic and histomorphometric study in an adult minipig model. Implant Dent. 26, 357-366. doi: 10.1097/id.0000000000000560

Dohan Ehrenfest, D. M., Coelho, P. G., Kang, B. S., Sul, Y. T., and Albrektsson, T. (2010). Classification of osseointegrated implant surfaces: materials, chemistry and topography. Trends Biotechnol. 28, 198-206. doi: 10.1016/j.tibtech.2009. 12.003

Dohan Ehrenfest, D. M., Vazquez, L., Park, Y. J., Sammartino, G., and Bernard, J. P. (2011). Identification card and codification of the chemical and morphological characteristics of 14 dental implant surfaces. J. Oral Implantol. 37, 525-542. doi: 10.1563/aaid-joi-d-11-00080

Dolanmaz, D., Saglam, M., Inan, O., Dundar, N., Alniacik, G., Gursoy Trak, B., et al. (2015). Monitoring bone morphogenetic protein-2 and -7, soluble receptor activator of nuclear factor-kappaB ligand and osteoprotegerin levels in the peri-implant sulcular fluid during the osseointegration of hydrophilic-modified sandblasted acid-etched and sandblasted acid-etched surface dental implants. J. Periodontal Res. 50, 62-73. doi: 10.1111/jre.12182

Dunne, W. M. Jr. (2002). Bacterial adhesion: seen any good biofilms lately. Clin. Microbiol. Rev. 15, 155-166. doi: 10.1128/cmr.15.2.155-166.2002

Duraccio, D., Mussano, F., and Faga, M. G. (2015). Biomaterials for dental implants: current and future trends. J. Mater. Sci. 50, 4779-4812. doi: 10.1007/ s10853-015-9056-3

Durmus, N. G., and Webster, T. J. (2012). Nanostructured titanium: the ideal material for improving orthopedic implant efficacy. Nanomedicine 7, 791-793. doi: $10.2217 / \mathrm{nnm} .12 .53$

Ehrenfest, D. M. D., Coelho, P. G., Kang, B.-S., Sul, Y. T., and Albrektsson, T. (2010). Classification of osseointegrated implant surfaces: materials, chemistry and topography. Trends Biotechnol. 28, 198-206. doi: 10.1016/j.tibtech.2009. 12.003

Ellingsen, J. (1995). Pretreatment of titanium implants with fluoride improves their retention in bone. J. Mater. Sci. Mater. Med. 6, 749-753. doi: 10.1007/ bf00134312

Ellingsen, J. E., Johansson, C. B., Wennerberg, A., and Holmen, A. (2004). Improved retention and bone-tolmplant contact with fluoride-modified titanium implants. Int. J. Oral Maxillofac. Implants 19, 659-666.

Ellingsen, J. E., Thomsen, P., and Lyngstadaas, S. P. (2006). Advances in dental implant materials and tissue regeneration. Periodontol 41, 136-156. doi: 10. 1111/j.1600-0757.2006.00175.x

Eriksson, C., Nygren, H., and Ohlson, K. (2004). Implantation of hydrophilic and hydrophobic titanium discs in rat tibia: cellular reactions on the surfaces during the first 3 weeks in bone. Biomaterials 25, 4759-4766. doi: 10.1016/j. biomaterials.2003.12.006

Erisken, C., Kalyon, D. M., and Wang, H. (2008). Functionally graded electrospun polycaprolactone and $\beta$-tricalcium phosphate nanocomposites for Tissue Eng applications. Biomaterials 29, 4065-4073. doi: 10.1016/j.biomaterials.2008. 06.022

Esposito, M., Ardebili, Y., and Worthington, H. V. (2014). Interventions for replacing missing teeth: different types of dental implants. Cochrane Database. Syst. Rev. 7:CD003815. doi: 10.1002/14651858.CD003815.pub4

Esposito, M., Hirsch, J., Lekholm, U., and Thomsen, P. (1999). Differential diagnosis and treatment strategies for biologic complications and failing oral implants: a review of the literature. Int. J. Oral Maxillofac. Implants 14, 473-490.

Farnoush, H., Aldıç, G., and Çimenoğlu, H. (2015). Functionally graded HA-TiO2 nanostructured composite coating on $\mathrm{Ti}-6 \mathrm{Al}-4 \mathrm{~V}$ substrate via electrophoretic deposition. Surf. Coat Technol. 265, 7-15. doi: 10.1016/j.surfcoat.2015. 01.069

Farronato, D., Mangano, F., Briguglio, F., Iorio-Siciliano, V., Riccitiello, F., and Guarnieri, R. (2014). Influence of Laser-Lok surface on immediate functional loading of implants in single-tooth replacement: a 2-year prospective clinical study. Int. J. Periodont. Restor. Dent. 34, 79-89. doi: 10.11607/prd.1747

Fischer, K., and Stenberg, T. (2012). Prospective 10-year cohort study based on a randomized controlled trial (RCT) on implant-supported full-arch maxillary prostheses. Part 1: sandblasted and acid-etched implants and mucosal tissue. Clin. Implant Dent. Relat. Res. 14, 808-815. doi: 10.1111/j.1708-8208.2011. 00389.x

Forsgren, J., Svahn, F., Jarmar, T., and Engqvist, H. (2007). Formation and adhesion of biomimetic hydroxyapatite deposited on titanium substrates. Acta Biomater. 3, 980-984. doi: 10.1016/j.actbio.2007.03.006
Franchi, M., Bacchelli, B., Martini, D., Pasquale, V. D., Orsini, E., Ottani, V., et al. (2004). Early detachment of titanium particles from various different surfaces of endosseous dental implants. Biomaterials 25, 2239-2246. doi: 10.1016/j. biomaterials.2003.09.017

Frantz, C., Stewart, K. M., and Weaver, V. M. (2010). The extracellular matrix at a glance. J. Cell Sci. 123, 4195-4200. doi: 10.1242/jcs.023820

Freeman, M. A. (1992). Hydroxyapatite coating of prostheses. J. Bone Joint Surg. Br. 74, 933-934. doi: 10.1302/0301-620x.74b6.1447263

Fu, C., Song, B., Wan, C., Savino, K., Wang, Y., Zhang, X., et al. (2015). Electrochemical growth of composite hydroxyapatite coatings for controlled release. Surf. Coat Technol. 276, 618-625. doi: 10.1016/j.surfcoat.2015.06.007

Gaggl, A., Schultes, G., Muller, W. D., and Karcher, H. (2000). Scanning electron microscopical analysis of laser-treated titanium implant surfaces-a comparative study. Biomaterials 21, 1067-1073. doi: 10.1016/s0142-9612(00)00002-8

Garcia, A. J., and Reyes, C. D. (2005). Bio-adhesive surfaces to promote osteoblast differentiation and bone formation. J. Dent. Res. 84, 407-413. doi: 10.1177/ 154405910508400502

Gautier, H., Daculsi, G., and Merle, C. (2001). Association of vancomycin and calcium phosphate by dynamic compaction: in vitro characterization and microbiological activity. Biomaterials 22, 2481-2487. doi: 10.1016/s01429612(00)00436-1

Germanier, Y., Tosatti, S., Broggini, N., Textor, M., and Buser, D. (2006). Enhanced bone apposition around biofunctionalized sandblasted and acidetched titanium implant surfaces. A histomorphometric study in miniature pigs. Clin. Oral Implants Res. 17, 251-257. doi: 10.1111/j.1600-0501.2005. 01222.x

Gittens, R. A., Scheideler, L., Rupp, F., Hyzy, S. L., Geis-Gerstorfer, J., Schwartz, Z., et al. (2014). A review on the wettability of dental implant surfaces II: Biological and clinical aspects. Acta Biomater. 10, 2907-2918. doi: 10.1016/j.actbio.2014. 03.032

Goel, M., Mehta, R., Kumar, A., Kumar, V., Bhayana, G., and Wadhwa, S. (2014). Implant surface modification and osseointegration-past, present and future. J. Oral Health Commun. Dent. 8, 113-118. doi: 10.5005/johcd-8-2-113

Golec, T. S., and Krauser, J. T. (1992). Long-term retrospective studies on hydroxyapatite coated endosteal and subperiosteal implants. Dent. Clin. North. Am 36, 39-65.

Gomez-de Diego, R., Mang-de la Rosa Mdel, R., Romero-Perez, M. J., Cutando-Soriano, A., and Lopez-Valverde-Centeno, A. (2014). Indications and contraindications of dental implants in medically compromised patients: update. Med. Oral Patol. Oral Cir. Bucal. 19, e483-e489. doi: 10.4317/medoral. 19565

Goodman, S. B., Yao, Z., Keeney, M., and Yang, F. (2013). The future of biologic coatings for orthopaedic implants. Biomaterials 34, 3174-3183. doi: 10.1016/j. biomaterials.2013.01.074

Gotfredsen, K., and Karlsson, U. (2001). A prospective 5-year study of fixed partial prostheses supported by implants with machined and $\mathrm{TiO} 2$-blasted surface. J. Prosthodont. 10, 2-7. doi: 10.1111/j.1532-849x.2001.00002.x

Gotfredsen, K., Wennerberg, A., Johansson, C., Skovgaard, L. T., and HjortingHansen, E. (1995). Anchorage of TiO2-blasted, HA-coated, and machined implants: an experimental study with rabbits. J. Biomed. Mater. Res. 29, 12231231. doi: 10.1002/jbm.820291009

Govindan, R., and Girija, E. (2014). Drug loaded phosphate glass/hydroxyapatite nanocomposite for orthopedic applications. J. Mater. Chem. B 2, 5468-5477. doi: $10.1039 / \mathrm{c} 4$ tb00549j

Grenho, L., Salgado, C., Fernandes, M., Monteiro, F., and Ferraz, M. (2015). Antibacterial activity and biocompatibility of three-dimensional nanostructured porous granules of hydroxyapatite and zinc oxide nanoparticles-An in vitro and in vivo study. Nanotechnology 26:315101. doi: 10.1088/0957-4484/26/31/315101

Gristina, A. G. (1987). Biomaterial-centered infection: microbial adhesion versus tissue integration. Science 237, 1588-1595. doi: 10.1126/science.3629258

Guarnieri, R., Serra, M., Bava, L., Grande, M., Farronato, D., and Iorio-Siciliano, V. (2014). The impact of a laser-microtextured collar on crestal bone level and clinical parameters under various placement and loading protocols. Int. J. Oral Maxillofac. Implants 29, 354-363. doi: 10.11607/jomi.3250

Guida, L., Oliva, A., Basile, M. A., Giordano, M., Nastri, L., and Annunziata, M. (2013). Human gingival fibroblast functions are stimulated by oxidized nanostructured titanium surfaces. J. Dent. 41, 900-907. doi: 10.1016/j.jdent.2013. 07.009 
Guo, H., Khor, K. A., Boey, Y. C., and Miao, X. (2003). Laminated and functionally graded hydroxyapatite/yttria stabilized tetragonal zirconia composites fabricated by spark plasma sintering. Biomaterials 24, 667-675. doi: 10.1016/s0142-9612(02)00381-2

Gupta, A., Dhanraj, M., and Sivagami, G. (2010). Status of surface treatment in endosseous implant: a literary overview. Indian J. Dent. Res. 21, 433-438. doi: 10.4103/0970-9290.70805

Gutwein, L., and Webster, T. (2004). Increased viable osteoblast density in the presence of nanophase compared to conventional alumina and titania particles. Biomaterials 25, 4175-4183. doi: 10.1016/j.biomaterials.2003.10.090

György, E., Mihailescu, I., Serra, P., Pérez Del Pino, A., and Morenza, J. L. (2002). Crown-Like structure development on titanium exposed to multipulse Nd:YAG laser irradiation. Appl. Phys. A Mater. 74, 755-759. doi: 10.1007/s003390201307

Habibovic, P., Barrere, F., Van Blitterswijk, C. A., de Groot, K., and Layrolle, P. (2002). Biomimetic hydroxyapatite coating on metal implants. J. Am. Ceram. Soc. 85, 517-522. doi: 10.1111/j.1151-2916.2002.tb00126.x

Habibovic, P., Li, J., Van Der Valk, C. M., Meijer, G., Layrolle, P., Van Blitterswijk, C. A., et al. (2005). Biological performance of uncoated and octacalcium phosphate-coated Ti6Al4V. Biomaterials 26, 23-36. doi: 10.1016/j.biomaterials. 2004.02.026

Habraken, W. J. E. M., Tao, J., Brylka, L. J., Friedrich, H., Bertinetti, L., Schenk, A. S., et al. (2013). Ion-association complexes unite classical and non-classical theories for the biomimetic nucleation of calcium phosphate. Nat. Commun. 4:1507. doi: $10.1038 /$ ncomms 2490

Han, J., Zhang, X., Tang, Z., Zhang, L., Shi, D., and Meng, H. (2016). A prospective, multicenter study assessing the DENTSPLY Implants, OsseoSpeed() TX, length $6 \mathrm{~mm}$ in the posterior maxilla and mandible: a 1-year follow-up study. Clin. Oral Implants Res. 27, 452-457. doi: 10.1111/clr.12587

Hao, Y., Yang, R., Niinomi, M., Kuroda, D., Zhou, Y., Fukunaga, K., et al. (2003). Aging response of the Young's modulus and mechanical properties of Ti-29Nb13Ta-4.6 Zr for biomedical applications. Metal. Mater. Trans. A 34, 1007-1012. doi: 10.1007/s11661-003-0230-x

Harris, L. G., and Richards, R. G. (2006). Staphylococci and implant surfaces: a review. Injury 37, S3-S14. doi: 10.1016/j.injury.2006.04.003

He, L.-H., and Swain, M. V. (2009). Enamel-a functionally graded natural coating. J. Dent. 37, 596-603. doi: 10.1016/j.jdent.2009.03.019

Hedia, H. (2005). Design of functionally graded dental implant in the presence of cancellous bone. J. Biomed. Mater. Res. B 75, 74-80. doi: 10.1002/jbm.b.30275

Hedia, H. S. (2005). Effect of cancellous bone on the functionally graded dental implant concept. Biomed. Mater. Eng. 15, 199-209.

Hedia, H., and Mahmoud, N. A. (2004). Design optimization of functionally graded dental implant. Biomed. Mater. Eng. 14, 133-143.

Hetrick, E. M., and Schoenfisch, M. H. (2006). Reducing implant-related infections: active release strategies. Chem. Soc. Rev. 35, 780-789. doi: 10.1039/b515219b

Hirakawa, Y., Jimbo, R., Shibata, Y., Watanabe, I., Wennerberg, A., and Sawase, T. (2013). Accelerated bone formation on photo-induced hydrophilic titanium implants: an experimental study in the dog mandible. Clin. Oral Implants Res. 24, 139-144. doi: 10.1111/j.1600-0501.2011.02401.x

Hisbergues, M., Vendeville, S., and Vendeville, P. (2009). Zirconia: Established facts and perspectives for a biomaterial in dental implantology. J. Biomed. Mater. Res. B 88, 519-529. doi: 10.1002/jbm.b.31147

Hollander, D. A., Von Walter, M., Wirtz, T., Sellei, R., Schmidt-Rohlfing, B., Paar, O., et al. (2006). Structural, mechanical and in vitro characterization of individually structured $\mathrm{Ti}-6 \mathrm{Al}-4 \mathrm{~V}$ produced by direct laser forming. Biomaterials 27, 955-963. doi: 10.1016/j.biomaterials.2005.07.041

Hollinger, J. O., Schmitt, J. M., Buck, D. C., Shannon, R., Joh, S. P., Zegzula, H. D., et al. (1998). Recombinant human bone morphogenetic protein-2 and collagen for bone regeneration. J. Biomed. Mater. Res. 43, 356-364.

Hotchkiss, K. M., Reddy, G. B., Hyzy, S. L., Schwartz, Z., Boyan, B. D., and OlivaresNavarrete, R. (2016). Titanium surface characteristics, including topography and wettability, alter macrophage activation. Acta Biomater. 31, 425-434. doi: 10.1016/j.actbio.2015.12.003

Hrabe, N. W., Heinl, P., Flinn, B., Körner, C., and Bordia, R. K. (2011). Compression-compression fatigue of selective electron beam melted cellular titanium (Ti-6Al-4V). J. Biomed. Mater. Res. B 99, 313-320. doi: 10.1002/jbm.b. 31901

Huang, M., Wang, R., Thompson, V., Rekow, D., and Soboyejo, W. O. (2007). Bioinspired design of dental multilayers. J. Mater. Sci. Mater. Med. 18, 57-64. doi: 10.1007/s10856-006-0662-660
Huang, R., Lu, S., and Han, Y. (2013). Role of grain size in the regulation of osteoblast response to Ti-25Nb-3Mo-3Zr-2Sn alloy. Colloids Surf. B Biointerf. 111, 232-241. doi: 10.1016/j.colsurfb.2013.06.007

Huang, Y., Zhang, X., Mao, H., Li, T., Zhao, R., Yan, Y., et al. (2015). Osteoblastic cell responses and antibacterial efficacy of $\mathrm{Cu} / \mathrm{Zn}$ co-substituted hydroxyapatite coatings on pure titanium using electrodeposition method. RSC Adv. 5, 1707617086. doi: 10.1039/c4ra12118j

Huh, J.-B., Kim, S.-E., Kim, H.-E., Kang, S.-S., Choi, K.-H., Jeong, C.-M., et al. (2012). Effects of anodized implants coated with Escherichia coli-derived rhBMP-2 in beagle dogs. Int. J. Oral Maxillofac. Surg. 41, 1577-1584. doi: 10.1016/j.ijom.2012.04.005

Hung, K.-Y., Lo, S.-C., Shih, C.-S., Yang, Y.-C., Feng, H.-P., and Lin, Y.-C. (2013). Titanium surface modified by hydroxyapatite coating for dental implants. Surf. Coat Technol. 231, 337-345. doi: 10.1016/j.surfcoat.2012.03.037

Hunziker, E. B., Enggist, L., Kuffer, A., Buser, D., and Liu, Y. (2012). Osseointegration: the slow delivery of BMP-2 enhances osteoinductivity. Bone 51, 98-106. doi: 10.1016/j.bone.2012.04.004

Isidor, F. (2006). Influence of forces on peri-implant bone. Clin. Oral Implants Res. 17, 8-18. doi: 10.1111/j.1600-0501.2006.01360.x

Ivanoff, C. J., Hallgren, C., Widmark, G., Sennerby, L., and Wennerberg, A. (2001). Histologic evaluation of the bone integration of $\mathrm{TiO}(2)$ blasted and turned titanium microimplants in humans. Clin. Oral Implants Res. 12, 128-134. doi: 10.1034/j.1600-0501.2001.012002128.x

Ivanoff, C. J., Widmark, G., Johansson, C., and Wennerberg, A. (2003). Histologic evaluation of bone response to oxidized and turned titanium micro-implants in human jawbone. Int. J. Oral Maxillofac. Implants 18, 341-348.

Jabbari, Y. S. A., Fehrman, J., Barnes, A. C., Zapf, A. M., Zinelis, S., and Berzins, D. W. (2012). Titanium nitride and nitrogen ion implanted coated dental materials. Coatings 2, 160-178. doi: 10.3390/coatings 2030160

Javed, F., Ahmed, H. B., Crespi, R., and Romanos, G. E. (2013). Role of primary stability for successful osseointegration of dental implants: Factors of influence and evaluation. Interv. Med. Appl. Sci. 5, 162-167. doi: 10.1556/imas.5.2013.4.3

Jemat, A., Ghazali, M. J., Razali, M., and Otsuka, Y. (2015). Surface modifications and their effects on titanium dental implants. Biomed. Res. Int. 2015:791725. doi: $10.1155 / 2015 / 791725$

Jenny, G., Jauernik, J., Bierbaum, S., Bigler, M., Grätz, K. W., Rücker, M., et al. (2016). A systematic review and meta-analysis on the influence of biological implant surface coatings on periimplant bone formation. J. Biomed. Mater. Res. A 104, 2898-2910. doi: 10.1002/jbm.a.35805

Ji, B., and Gao, H. (2004). Mechanical properties of nanostructure of biological materials. J. Mech. Phys. Solids 52, 1963-1990. doi: 10.1016/j.jmps.2004.03.006

Jiang, Q. H., Liu, L., Peel, S., Yang, G. L., Zhao, S. F., and He, F. M. (2013). Bone response to the multilayer BMP-2 gene coated porous titanium implant surface. Clin. Oral Implants Res. 24, 853-861. doi: 10.1111/j.1600-0501.2011.02383.x

Johnson, B. W. (1992). HA-coated dental implants: long-term consequences. J. Calif. Dent. Assoc. 20, 33-41.

Joshi, G. V., Duan, Y., Neidigh, J., Koike, M., Chahine, G., Kovacevic, R., et al. (2013). Fatigue testing of electron beam-melted Ti-6Al-4V ELI alloy for dental implants. J. Biomed. Mater. Res. B 101, 124-130. doi: 10.1002/jbm.b.32825

Jovanovic, S. A., Kenney, E. B., Carranza, F. A. Jr., and Donath, K. (1993). The regenerative potential of plaque-induced peri-implant bone defects treated by a submerged membrane technique: an experimental study. Int. J. Oral Maxillofac. Implants 8, 13-18.

Jungner, M., Lundqvist, P., and Lundgren, S. (2005). Oxidized titanium implants (Nobel Biocare TiUnite) compared with turned titanium implants (Nobel Biocare mark III) with respect to implant failure in a group of consecutive patients treated with early functional loading and two-stage protocol. Clin. Oral Implants Res. 16, 308-312. doi: 10.1111/j.1600-0501.2005.01101.x

Junker, R., Dimakis, A., Thoneick, M., and Jansen, J. A. (2009). Effects of implant surface coatings and composition on bone integration: a systematic review. Clin. Oral Implants Res. 20, 185-206. doi: 10.1111/j.1600-0501.2009.01777.x

Kasemo, B. (2002). Biological surface science. Surf. Sci. 500, 656-677. doi: 10.1016/ s0039-6028(01)01809-x

Kawai, T., Mieki, A., Ohno, Y., Umemura, M., Kataoka, H., Kurita, S., et al. (1993). Osteoinductive activity of composites of bone morphogenetic protein and pure titanium. Clin. Orthop. Relat. Res. 290, 296-305.

Khan, W., Muntimadugu, E., Jaffe, M., and Domb, A. J. (2014). "Implantable medical devices," in Focal Controlled Drug Delivery, eds A. J. Domb and W. Khan (Boston, MA: Springer US), 33-59. doi: 10.1007/978-1-4614-9434-8_2pp 
Khor, K., Gu, Y., Quek, C., and Cheang, P. (2003). Plasma spraying of functionally graded hydroxyapatite/Ti-6Al-4V coatings. Surf. Coat. Technol. 168, 195-201. doi: $10.1016 / \mathrm{s} 0257-8972(03) 00238-\mathrm{x}$

Kim, N.-H., Lee, S.-H., Ryu, J.-J., Choi, K.-H., and Huh, J.-B. (2015). Effects of rhBMP-2 on sandblasted and acid etched titanium implant surfaces on bone regeneration and osseointegration: Spilt-mouth designed pilot study. Biomed Res. Int. 2015:459393. doi: 10.1155/2015/459393

Kim, S. E., Kim, C. S., Yun, Y. P., Yang, D. H., Park, K., Kim, S. E., et al. (2014). Improving osteoblast functions and bone formation upon BMP-2 immobilization on titanium modified with heparin. Carbohydr. Polym. 114, 123-132. doi: 10.1016/j.carbpol.2014.08.005

Kim, Y. K., Kim, S. G., Kim, J. H., Yi, Y. J., and Yun, P. Y. (2012). Prospective study of tapered resorbable blasting media surface implant stability in the maxillary posterior area. Oral Surg. Oral Med. Oral Pathol. Oral Radiol. 114, e19-e24. doi: 10.1016/j.tripleo.2011.08.028

Kiran, A., Balu, R., and Kumar, T. (2012). Vero cell viability and human osteoblast cell response to electrospun phase controlled titania nanofibers. J. Biomater. Tissue Eng. 2, 292-298. doi: 10.1166/jbt.2012.1053

Kitsugi, T., Nakamura, T., Oka, M., Senaha, Y., Goto, T., and Shibuya, T. (1996). Bone-bonding behavior of plasma-sprayed coatings of BioglassR, AW-glass ceramic, and tricalcium phosphate on titanium alloy. J. Biomed. Mater. Res. 30, 261-269. doi: 10.1002/(sici)1097-4636(199602)30:2<261:aid-jbm17<3.0. co;2-p

Knabe, C., Klar, F., Fitzner, R., Radlanski, R. J., and Gross, U. (2002). In vitro investigation of titanium and hydroxyapatite dental implant surfaces using a rat bone marrow stromal cell culture system. Biomaterials 23, 3235-3245. doi: 10.1016/s0142-9612(02)00078-9

Korn, P., Schulz, M., Hintze, V., Range, U., Mai, R., Eckelt, U., et al. (2014). Chondroitin sulfate and sulfated hyaluronan-containing collagen coatings of titanium implants influence peri-implant bone formation in a minipig model. J. Biomed. Mater. Res. A 102, 2334-2344. doi: 10.1002/jbm.a.34913

Krishna, B. V., Bose, S., and Bandyopadhyay, A. (2007). Low stiffness porous Ti structures for load-bearing implants. Acta Biomater. 3, 997-1006. doi: 10.1016/ j.actbio.2007.03.008

Kumar, R. R., and Wang, M. (2002). Modulus and hardness evaluations of sintered bioceramic powders and functionally graded bioactive composites by nanoindentation technique. Mater. Sci. Eng. A 338, 230-236. doi: 10.1016/s09215093(02)00080-1

Kutty, M., and Bhaduri, S. (2004). Gradient surface porosity in titanium dental implants: relation between processing parameters and microstructure. J. Mater. Sci. Mater. Med. 15, 145-150. doi: 10.1023/b:jmsm.0000011815.50383.bd

Lan, J., Wang, Z., Shi, B., Xia, H., and Cheng, X. (2007). The influence of recombinant human BMP-2 on bone-implant osseointegration: biomechanical testing and histomorphometric analysis. Int. J. Oral Maxillofac. Surg. 36, 345349. doi: 10.1016/j.ijom.2006.10.019

Lan, J., Wang, Z., Wang, Y., Wang, J., and Cheng, X. (2006). The effect of combination of recombinant human bone morphogenetic protein-2 and basic fibroblast growth factor or insulin-like growth factor-I on dental implant osseointegration by confocal laser scanning microscopy. J. Periodontol. 77, 357-363. doi: 10.1902/jop.2006.050016

Laoui, T., Santos, E., Osakada, K., Shiomi, M., Morita, M., Shaik, S., et al. (2006). Properties of titanium dental implant models made by laser processing. Proc. Inst. Mech. Eng. C J. Mech. Eng. Sci. 220, 857-863. doi: 10.1111/j.1708-8208. 2011.00416.x

Laurent, F., Bignon, A., Goldnadel, J., Chevalier, J., Fantozzi, G., Viguier, E., et al. (2008). A new concept of gentamicin loaded HAP/TCP bone substitute for prophylactic action: in vitro release validation. J. Mater. Sci. Mater. Med. 19, 947-951. doi: 10.1007/s10856-007-0163-9

Le Guehennec, L., Soueidan, A., Layrolle, P., and Amouriq, Y. (2007). Surface treatments of titanium dental implants for rapid osseointegration. Dent. Mater. 23, 844-854. doi: 10.1016/j.dental.2006.06.025

Lee, H., Dregia, S., Akbar, S., and Alhoshan, M. (2010). Growth of 1-D TiO 2 nanowires on Ti and Ti alloys by oxidation. J. Nanomater. 2010:64.

Lee, J. J., Rouhfar, L., and Beirne, O. R. (2000). Survival of hydroxyapatite-coated implants: a meta-analytic review. J. Oral Maxillofac. Surg. 58, 1372-1379. doi: 10.1053/joms.2000.18269

Lee, K., Mazare, A., and Schmuki, P. (2014). One-dimensional titanium dioxide nanomaterials: nanotubes. Chem. Rev. 114, 9385-9454. doi: 10.1021/ cr500061m
Lee, S. W., Hahn, B. D., Kang, T. Y., Lee, M. J., Choi, J. Y., Kim, M. K., et al. (2014), Hydroxyapatite and collagen combination-coated dental implants display better bone formation in the peri-implant area than the same combination plus bone morphogenetic protein-2-coated implants, hydroxyapatite only coated implants, and uncoated implants. J. Oral Maxillofac. Surg. 72, 53-60. doi: 10. 1016/j.joms.2013.08.031

Lee, S. Y., Koak, J. Y., Heo, S. J., Kim, S. K., Lee, S. J., and Nam, S. Y. (2010). Osseointegration of anodized titanium implants coated with poly (lactide-coglycolide)/basic fibroblast growth factor by electrospray. Int. J. Oral Maxillofac. Implants 25, 315-320.

Leeuwenburgh, S., Layrolle, P., Barrere, F., De Bruijn, J., Schoonman, J., Van Blitterswijk, C., et al. (2001). Osteoclastic resorption of biomimetic calcium phosphate coatings in vitro. J. Biomed. Mater. Res. A 56, 208-215. doi: 10.1002/ 1097-4636(200108)56:2<208::aid-jbm1085>3.0.co;2-r

Li, D., Ferguson, S. J., Beutler, T., Cochran, D. L., Sittig, C., Hirt, H. P., et al. (2002). Biomechanical comparison of the sandblasted and acid-etched and the machined and acid-etched titanium surface for dental implants. J. Biomed. Mater. Res. 60, 325-332. doi: 10.1002/jbm.10063

Li, L. H., Kong, Y. M., Kim, H. W., Kim, Y. W., Kim, H. E., Heo, S. J., et al. (2004). Improved biological performance of Ti implants due to surface modification by micro-arc oxidation. Biomaterials 25, 2867-2875. doi: 10.1016/j.biomaterials. 2003.09.048

Li, X., Wang, C., Zhang, W., and Li, Y. (2010). Fabrication and compressive properties of Ti6Al4V implant with honeycomb-like structure for biomedical applications. Rapid Prototyp. J. 16, 44-49. doi: 10.1108/1355254101101 1703

Li, X., Xie, J., Lipner, J., Yuan, X., Thomopoulos, S., and Xia, Y. (2009). Nanofiber scaffolds with gradations in mineral content for mimicking the tendon-to-bone insertion site. Nano Lett. 9, 2763-2768. doi: 10.1021/nl901582f

Li, Y., Qi, Y., Gao, Q., Niu, Q., Shen, M., Fu, Q., et al. (2015). Effects of a micro/nano rough strontium-loaded surface on osseointegration. Int. J. Nanomed. 10:4549. doi: $10.2147 /$ ijn.s84398

Lieberman, J. R., Daluiski, A., and Einhorn, T. A. (2002). The role of growth factors in the repair of bone. Biology and clinical applications. J. Bone Joint Surg. 84-a, 1032-1044. doi: 10.2106/00004623-200206000-00022

Lifland, M., Kim, D., and Okazaki, K. (1993). Mechanical properties of a Ti-6A1$4 \mathrm{~V}$ dental implant produced by electro-discharge compaction. Clin. Mater. 14, 13-19. doi: 10.1016/0267-6605(93)90042-6

Lin, D., Li, Q., Li, W., Zhou, S., and Swain, M. (2009). Design optimization of functionally graded dental implant for bone remodeling. Compos. B Eng. 40, 668-675. doi: 10.1016/j.compositesb.2009.04.015

Lin, X., de Groot, K., Wang, D., Hu, Q., Wismeijer, D., and Liu, Y. (2015). A review paper on biomimetic calcium phosphate coatings. Open Biomed. Eng. J. 9, 56-64. doi: 10.2174/1874120701509010056

Liu, Y., Enggist, L., Kuffer, A. F., Buser, D., and Hunziker, E. B. (2007). The influence of BMP-2 and its mode of delivery on the osteoconductivity of implan surfaces during the early phase of osseointegration. Biomaterials 28, 2677-2686. doi: 10.1016/j.biomaterials.2007.02.003

Liu, Y., Layrolle, P., de Bruijn, J., van Blitterswijk, C., and de Groot, K. (2001). Biomimetic coprecipitation of calcium phosphate and bovine serum albumin on titanium alloy. J. Biomed. Mater. Res. A 57, 327-335. doi: 10.1002/10974636(20011205) 57:3<327::aid-jbm1175>3.0.co;2-j

Lixin, X., Hu, X., Mehrhof, J., and Nelson, K. (2010). Clinical evaluation of a fixed (retrievable) implant-supported prosthesis in the edentulous jaw: A 5-year report. Quintessence Int. 41, 277-283.

Luginbuehl, V., Ruffieux, K., Hess, C., Reichardt, D., Von Rechenberg, B., and Nuss, K. (2010). Controlled release of tetracycline from biodegradable $\beta$-tricalcium phosphate composites. J. Biomed. Mater. Res. B 92, 341-352. doi: 10.1002/jbm. b. 31520

Lum, L. B., Beirne, O. R., and Curtis, D. (1991). Histological evaluation of hydroxyapatite-coated versus uncoated titanium blade implants in delayed applications. Int. J. Oral Maxillofac. Implants 6, 456-462.

Lutz, R., Srour, S., Nonhoff, J., Weisel, T., Damien, C. J., and Schlegel, K. A. (2010). Biofunctionalization of titanium implants with a biomimetic active peptide (P-15) promotes early osseointegration. Clin. Oral Implants Res. 21, 726-734. doi: $10.1111 / j .1600-0501.2009 .01904 . x$

Ma, Z., Kotaki, M., Inai, R., and Ramakrishna, S. (2005). Potential of nanofiber matrix as tissue-engineering scaffolds. Tissue Eng. 11, 101-109. doi: 10.1089/ ten.2005.11.101 
Maghdouri-White, Y., Bowlin, G. L., Lemmon, C. A., and Dréau, D. (2014). Mammary epithelial cell adhesion, viability, and infiltration on blended or coated silk fibroin-collagen type I electrospun scaffolds. Mater. Sci. Eng. C 43, 37-44. doi: 10.1016/j.msec.2014.06.037

Mandracci, P., Mussano, F., Rivolo, P., and Carossa, S. (2016). Surface treatments and functional coatings for biocompatibility improvement and bacterial adhesion reduction in dental implantology. Coatings 6:7. doi: 10.3390/ coatings 6010007

Mangano, C., Mangano, F. G., Shibli, J. A., Ricci, M., Perrotti, V., d'Avila, S., et al. (2012). Immediate loading of mandibular overdentures supported by unsplinted direct laser metal-forming implants: results from a 1-year prospective study. J. Periodontol. 83, 70-78. doi: 10.1902/jop.2011.110079

Mangano, C., Raspanti, M., Traini, T., Piattelli, A., and Sammons, R. (2009). Stereo imaging and cytocompatibility of a model dental implant surface formed by direct laser fabrication. J. Biomed. Mater. Res. A 88, 823-831. doi: 10.1002/jbm. a. 32033

Mangano, F., Maghaireh, H., and Calvo-Guirado, J. (2018). \#xe8. Engineering the bone-implant interface. Biomed. Res. Int. 2018:4956491. doi: 10.1155/2018/ 4956491

Mangano, F. G., Iezzi, G., Shibli, J. A., Pires, J. T., Luongo, G., Piattelli, A., et al. (2017). Early bone formation around immediately loaded implants with nanostructured calcium-incorporated and machined surface: a randomized, controlled histologic and histomorphometric study in the human posterior maxilla. Clin. Oral Investig. 21, 2603-2611. doi: 10.1007/s00784-017-2061-y

Manjubala, I., and Kumar, T. S. (2000). Effect of TiO2-Ag2O additives on the formation of calcium phosphate based functionally graded bioceramics. Biomaterials 21, 1995-2002. doi: 10.1016/s0142-9612(00)00092-2

Manjubala, I., Sivakumar, M., Sampathkumar, T., and Panduranga Rao, K. (2000). Synthesis and characterization of functional gradient materials using Indian corals. J. Mater. Sci. Mater. Med. 11, 705-709.

Mantripragada, V. P., and Jayasuriya, A. C. (2016). Bone regeneration using injectable BMP-7 loaded chitosan microparticles in rat femoral defect. Mater. Sci. Eng. C 63, 596-608. doi: 10.1016/j.msec.2016.02.080

Marković, S., Lukić, M. J., Škapin, S. D., Stojanović, B., and Uskoković, D. (2015). Designing, fabrication and characterization of nanostructured functionally graded HAp/BCP ceramics. Ceram. Int. 41, 2654-2667. doi: 10.1016/j.ceramint. 2014.10.079

Martini, D., Fini, M., Franchi, M., Pasquale, V. D., Bacchelli, B., Gamberini, M., et al. (2003). Detachment of titanium and fluorohydroxyapatite particles in unloaded endosseous implants. Biomaterials 24, 1309-1316. doi: 10.1016/ s0142-9612(02)00508-2

Massa, M. A., Covarrubias, C., Bittner, M., Fuentevilla, I. A., Capetillo, P., Von Marttens, A., et al. (2014). Synthesis of new antibacterial composite coating for titanium based on highly ordered nanoporous silica and silver nanoparticles. Mater. Sci. Eng. C 45, 146-153. doi: 10.1016/j.msec.2014.08.057

Massaro, C., Rotolo, P., De Riccardis, F., Milella, E., Napoli, A., Wieland, M., et al. (2002). Comparative investigation of the surface properties of commercial titanium dental implants. Part I: Chemical composition. J. Mater. Sci. Mater. Med. 13, 535-548.

Matarese, G., Ramaglia, L., Fiorillo, L., Cervino, G., Lauritano, F., and Isola, G. (2017). Implantology and periodontal disease: The panacea to problem solving. Open Dent. J. 11:460. doi: 10.2174/1874210601711010460

Matsui, Y., Ohno, K., Michi, K. I., and Yamagata, K. (1994). Experimental study of high-velocity flame-sprayed hydroxyapatite coated and noncoated titanium implants. Int. J. Oral Maxillofac. Implants 9, 1-15.

Matsuno, T., Watanabe, K., Ono, K., and Koishi, M. (1996). Sintering of zirconia coated hydroxyapatite particles. J. Ceram. Soc. Jpn. 104, 945-948. doi: 10.2109/ jcersj. 104.945

Matsuno, T., Watanabe, K., Ono, K., and Koishi, M. (1998). Preparation of laminated hydroxyapatite/zirconia sintered composite with the gradient composition. J. Mater. Sci. Lett. 17, 1349-1351.

Matsuno, T., Watanabe, K., Ono, K., and Koishi, M. (2000). Microstructure and mechanical properties of sintered body of zirconia coated hydroxyapatite particles. J. Mater. Sci. Lett. 19, 573-576. doi: 10.1023/A:1006722110462

McNamara, L. E., McMurray, R. J., Biggs, M. J., Kantawong, F., Oreffo, R. O., and Dalby, M. J. (2010). Nanotopographical control of stem cell differentiation. J. Tissue Eng. 2010:120623. doi: 10.4061/2010/120623

Mehrali, M., Shirazi, F. S., Mehrali, M., Metselaar, H. S. C., Kadri, N. A. B., and Osman, N. A. A. (2013). Dental implants from functionally graded materials. J. Biomed. Mater. Res. A 101, 3046-3057. doi: 10.1002/jbm.a. 34588

Mello, A. S. D. S., dos Santos, P. L., Marquesi, A., Queiroz, T. P., Margonar, R., and de Souza Faloni, A. P. (2016). Some aspects of bone remodeling around dental implants. Rev. Clín. Periodoncia Implant. Rehabil. Oral (in press).

Mendes, V. C., Moineddin, R., and Davies, J. E. (2007). The effect of discrete calcium phosphate nanocrystals on bone-bonding to titanium surfaces. Biomaterials 28, 4748-4755. doi: 10.1016/j.biomaterials.2007.07.020

Mendes, V. C., Moineddin, R., and Davies, J. E. (2009). Discrete calcium phosphate nanocrystalline deposition enhances osteoconduction on titaniumbased implant surfaces. J. Biomed. Mater. Res. A 90, 577-585. doi: 10.1002/jbm. a. 32126

Mendonça, G., Mendonça, D. B., Aragao, F. J., and Cooper, L. F. (2008). Advancing dental implant surface technology-from micron-to nanotopography. Biomaterials 29, 3822-3835. doi: 10.1016/j.biomaterials.2008.05.012

Meng, H. W., Chien, E. Y., and Chien, H. H. (2016). Dental implant bioactive surface modifications and their effects on osseointegration: a review. Biomark Res. 4:24.

Merdji, A., Bouiadjra, B. B., Chikh, B. O., Mootanah, R., Aminallah, L., Serier, B., et al. (2012). Stress distribution in dental prosthesis under an occlusal combined dynamic loading. Mater. Des. 36, 705-713. doi: 10.1016/j.matdes.2011.12.006

Meyle, J. (1999). "Cell adhesion and spreading on different implant surfaces," in Proceedings of the 3rd European Workshop on Periodontology (Batavia, IL: Quintessence), 55-72.

Morejón-Alonso, L., Carrodeguas, R. G., García-Menocal, J. A. D., Pérez, J. A. A., and Manent, S. M. (2007). Effect of sterilization on the properties of CDHA-OCP-beta-TCP biomaterial. Mat. Res. 10, 15-20. doi: 10.1590/s151614392007000100005

Morra, M. (2006). Biochemical modification of titanium surfaces: peptides and ECM proteins. Eur. Cell Mater. 12, 1-15. doi: 10.22203/ecm.v012a01

Morra, M. (2007). Biomolecular modification of implant surfaces. Expert Rev. Med. Devices 4, 361-372. doi: 10.1586/17434440.4.3.361

Morra, M., Cassinelli, C., Cascardo, G., Bollati, D., and Rodriguez, Y. B. R. (2010). Multifunctional implant surfaces: surface characterization and bone response to acid-etched Ti implants surface-modified by fibrillar collagen I. J. Biomed. Mater. Res. A 94, 271-279. doi: 10.1002/jbm.a.32702

Morra, M., Cassinelli, C., Cascardo, G., Mazzucco, L., Borzini, P., Fini, M., et al. (2006). Collagen I-coated titanium surfaces: mesenchymal cell adhesion and in vivo evaluation in trabecular bone implants. J. Biomed. Mater. Res. A 78, 449-458. doi: 10.1002/jbm.a.30783

Mueller, W. D., Gross, U., Fritz, T., Voigt, C., Fischer, P., Berger, G., et al. (2003). Evaluation of the interface between bone and titanium surfaces being blasted by aluminium oxide or bioceramic particles. Clin. Oral Implants Res. 14, 349-356. doi: 10.1034/j.1600-0501.2003.00791.x

Murr, L., Gaytan, S., Medina, F., Lopez, H., Martinez, E., Machado, B., et al. (2010). Next-generation biomedical implants using additive manufacturing of complex, cellular and functional mesh arrays. Philos. Trans. A Math. Phys. Eng. Sci. 368, 1999-2032. doi: 10.1098/rsta.2010.0010

Nag, S., and Banerjee, R. (2012). Fundamentals of medical implant materials. ASM Handb. 23, 6-17. doi: 10.31399/asm.hb.v23.a0005682

Nagano, M., Kitsugi, T., Nakamura, T., Kokubo, T., and Tanahashi, M. (1996). Bone bonding ability of an apatite-coated polymer produced using a biomimetic method: A mechanical and histological study in vivo. J. Biomed. Mater. Res. 31, 487-494. doi: 10.1002/(sici)1097-4636(199608)31:4<487::aid-jbm8>3.0.co;2-h

Nazarpour, S. (2013). Thin Films and Coatings in Biology. Berlin: Springer Science \& Business Media, doi: 10.1007/978-94-007-2592-2598

Neugebauer, J., Traini, T., Thams, U., Piattelli, A., and Zöller, J. E. (2006). Periimplant bone organization under immediate loading state. Circularly polarized light analyses: a minipig study. J. Periodontol. 77, 152-160. doi: 10.1902/jop. 2006.040360

Nevins, M., Kim, D. M., Jun, S.-H., Guze, K., Schupbach, P., and Nevins, M. L. (2010). Histologic evidence of a connective tissue attachment to laser microgrooved abutments: a canine study. Int. J. Periodont. Restor. Dent. 30, 245-255.

Nikolidakis, D., Meijer, G. J., Oortgiesen, D. A., Walboomers, X. F., and Jansen, J. A. (2009). The effect of a low dose of transforming growth factor $\beta 1$ (TGF- $\beta 1$ ) on the early bone-healing around oral implants inserted in trabecular bone. Biomaterials 30, 94-99. doi: 10.1016/j.biomaterials.2008. 09.022 
Nomura, N., Sakamoto, K., Takahashi, K., Kato, S., Abe, Y., Doi, H., et al. (2010). Fabrication and mechanical properties of porous Ti/HA composites for bone fixation devices. Mater. Trans. 51, 1449-1454. doi: 10.2320/matertrans. $\mathrm{m} 2010092$

Noshi, T., Yoshikawa, T., Dohi, Y., Ikeuchi, M., Horiuchi, K., Ichijima, K., et al. (2001). Recombinant human bone morphogenetic protein-2 potentiates the in vivo osteogenic ability of marrow/hydroxyapatite composites. Artif. Organs 25, 201-208. doi: 10.1046/j.1525-1594.2001.025003201.x

Novaes, A. B. Jr., Papalexiou, V., Grisi, M. F., Souza, S. S., Taba, M. Jr., and Kajiwara, J. K. (2004). Influence of implant microstructure on the osseointegration of immediate implants placed in periodontally infected sites: a histomorphometric study in dogs. Clin. Oral Implants Res. 15, 34-43. doi: 10.1046/j.1600-0501.2003. 00968.x

Novaes, A. B. Jr., Souza, S. L., de Oliveira, P. T., and Souza, A. M. (2002). Histomorphometric analysis of the bone-implant contact obtained with 4 different implant surface treatments placed side by side in the dog mandible. Int. J. Oral Maxillofac. Implants 17, 377-383.

Okazaki, Y., Ito, Y., Kyo, K., and Tateishi, T. (1996). Corrosion resistance and corrosion fatigue strength of new titanium alloys for medical implants without V and Al. Mater. Sci. Eng. A 213, 138-147. doi: 10.1016/0921-5093(96) 10247-1

Oldani, C., and Dominguez, A. (2012). “Titanium as a biomaterial for implants," in Recent Advances in Arthroplasty ed. S. K. Fokter (London: IntechOpen), doi: $10.5772 / 27413$

Olivares-Navarrete, R., Raines, A. L., Hyzy, S. L., Park, J. H., Hutton, D. L., Cochran, D. L., et al. (2012). Osteoblast maturation and new bone formation in response to titanium implant surface features are reduced with age. J. Bone Miner. Res. 27, 1773-1783. doi: 10.1002/jbmr.1628

Orsini, G., Assenza, B., Scarano, A., Piattelli, M., and Piattelli, A. (2000). Surface analysis of machined versus sandblasted and acid-etched titanium implants. Int. J. Oral Maxillofac. Implants 15, 779-784.

Osman, R., and Swain, M. (2015). A critical review of dental implant materials with an emphasis on titanium versus zirconia. Materials 8, 932-958. doi: 10.3390/ ma8030932

Östman, P. O., Hupalo, M., Del Castillo, R., Emery, R. W., Cocchetto, R., Vincenzi, G., et al. (2010). Immediate provisionalization of NanoTite implants in support of single-tooth and unilateral restorations: one-year interim report of a prospective, multicenter study. Clin. Implant. Dent. Relat. Res. 12, e47-e55. doi: 10.1111/j.1708-8208.2009.00166.x

Östman, P. O., Wennerberg, A., Ekestubbe, A., and Albrektsson, T. (2013). Immediate occlusal loading of NanoTite ${ }^{\mathrm{TM}}$ tapered implants: a prospective 1-year clinical and radiographic study. Clin. Implant. Dent. Relat. Res. 15, 809-818. doi: 10.1111/j.1708-8208.2011.00437.x

Oyane, A., Yokoyama, Y., Uchida, M., and Ito, A. (2006). The formation of an antibacterial agent-apatite composite coating on a polymer surface using a metastable calcium phosphate solution. Biomaterials 27, 3295-3303. doi: 10. 1016/j.biomaterials.2006.01.029

Özcan, M., Allahbeickaraghi, A., and Dündar, M. (2012). Possible hazardous effects of hydrofluoric acid and recommendations for treatment approach: a review. Clin. Oral Investig. 16, 15-23. doi: 10.1007/s00784-011-0636-6

Özcan, M., and Hämmerle, C. (2012). Titanium as a reconstruction and implant material in dentistry: advantages and pitfalls. Materials 5, 1528-1545. doi: 10 . 3390/ma5091528

Ozdemir, Z., Ozdemir, A., and Basim, G. (2016). Application of chemical mechanical polishing process on titanium based implants. Mater. Sci. Eng. C 68, 383-396. doi: 10.1016/j.msec.2016.06.002

Pal, S., Tak, Y. K., and Song, J. M. (2007). Does the antibacterial activity of silver nanoparticles depend on the shape of the nanoparticle? A study of the Gramnegative bacterium Escherichia coli. Appl. Environ. Microbiol. 73, 1712-1720. doi: 10.1128/AEM.02218-2216

Palmer, R. M., Howe, L. C., and Palmer, P. J. (2002). Implants in Clinical Dentistry. Boca Raton, FL: CRC Press.

Parithimarkalaignan, S., and Padmanabhan, T. (2013). Osseointegration: an update. J. Indian Prosthodont. Soc. 13, 2-6. doi: 10.1007/s13191-013-0252-z

Park, J., Bauer, S., Schlegel, K. A., Neukam, F. W., von der Mark, K., and Schmuki, P. (2009). TiO2 nanotube surfaces: $15 \mathrm{~nm}$-an optimal length scale of surface topography for cell adhesion and differentiation. Small 5, 666-671. doi: 10.1002/ smll.200801476
Park, J., Bauer, S., von der Mark, K., and Schmuki, P. (2007). Nanosize and vitality: TiO2 nanotube diameter directs cell fate. Nano Lett. 7, 1686-1691. doi: $10.1021 / \mathrm{nl} 070678 \mathrm{~d}$

Park, J.-M., Koak, J.-Y., Jang, J.-H., Han, C.-H., Kim, S.-K., and Heo, S.-J. (2006). Osseointegration of anodized titanium implants coated with fibroblast growth factor-fibronectin (FGF-FN) fusion protein. Int. J. Oral Maxillofac. Implants 21, 859-866.

Park, J. Y., Gemmell, C. H., and Davies, J. E. (2001). Platelet interactions with titanium: modulation of platelet activity by surface topography. Biomaterials 22, 2671-2682. doi: 10.1016/s0142-9612(01)00009-6

Pecora, G. E., Ceccarelli, R., Bonelli, M., Alexander, H., and Ricci, J. L. (2009). Clinical evaluation of laser microtexturing for soft tissue and bone attachment to dental implants. Implant Dent. 18, 57-66. doi: 10.1097/ID. $0 \mathrm{~b} 013 \mathrm{e} 31818 \mathrm{c} 5 \mathrm{a} 6 \mathrm{~d}$

Peng, L., Eltgroth, M. L., LaTempa, T. J., Grimes, C. A., and Desai, T. A. (2009). The effect of $\mathrm{TiO} 2$ nanotubes on endothelial function and smooth muscle proliferation. Biomaterials 30, 1268-1272. doi: 10.1016/j.biomaterials.2008. 11.012

Peter, B., Pioletti, D. P., Laib, S., Bujoli, B., Pilet, P., Janvier, P., et al. (2005). Calcium phosphate drug delivery system: influence of local zoledronate release on bone implant osteointegration. Bone 36, 52-60. doi: 10.1016/j.bone.2004. 10.004

Piattelli, M., Scarano, A., Paolantonio, M., Iezzi, G., Petrone, G., and Piattelli, A. (2002). Bone response to machined and resorbable blast material titanium implants: an experimental study in rabbits. J. Oral Implantol. 28, 2-8. doi: 10.1563/1548-1336(2002)028<0002:brtmar >2.3.co;2

Poinern, G. E., Brundavanam, R. K., Mondinos, N., and Jiang, Z. T. (2009). Synthesis and characterisation of nanohydroxyapatite using an ultrasound assisted method. Ultrason. Sonochem. 16, 469-474. doi: 10.1016/j.ultsonch. 2009.01.007

Pompe, W., Worch, H., Epple, M., Friess, W., Gelinsky, M., Greil, P., et al. (2003). Functionally graded materials for biomedical applications. Mater. Sci. Eng. A 362, 40-60.

Pramanik, S., Pingguan-Murphy, B., and Osman, N. A. A. (2012). Progress of key strategies in development of electrospun scaffolds: bone tissue. Sci. Technol. Adv. Mater. 13:043002. doi: 10.1088/1468-6996/13/4/043002

Prasad, K., Bazaka, O., Chua, M., Rochford, M., Fedrick, L., Spoor, J., et al. (2017). Metallic biomaterials: current challenges and opportunities. Materials 10:884. doi: $10.3390 / \mathrm{ma1} 0080884$

Puckett, S., Pareta, R., and Webster, T. J. (2008). Nano rough micron patterned titanium for directing osteoblast morphology and adhesion. Int. J. Nanomed. 3 , 229-241.

Puleo, D. A., and Nanci, A. (1999). Understanding and controlling the boneimplant interface. Biomaterials 20, 2311-2321. doi: 10.1016/s0142-9612(99) 00160-X

Puleo, D. A., and Thomas, M. V. (2006). Implant surfaces. Dent. Clin. North Am. 2006, 323-338.

Quirynen, M., and Van Assche, N. (2012). RCT comparing minimally with moderately rough implants. Part 2: microbial observations. Clin. Oral Implants Res. 23, 625-634. doi: 10.1111/j.1600-0501.2011.02255.x

Radin, S., Campbell, J. T., Ducheyne, P., and Cuckler, J. M. (1997). Calcium phosphate ceramic coatings as carriers of vancomycin. Biomaterials 18, $777-$ 782. doi: 10.1016/s0142-9612(96)00190-1

Raghavendra, S., Wood, M. C., and Taylor, T. D. (2005). Early wound healing around endosseous implants: a review of the literature. Int. J. Oral Maxillofac. Implants 20, 425-431.

Rajesh, P., Mohan, N., Yokogawa, Y., and Varma, H. (2013). Pulsed laser deposition of hydroxyapatite on nanostructured titanium towards drug eluting implants. Mater. Sci. Eng. C 33, 2899-2904. doi: 10.1016/j.msec.2013.03.013

Ramazanoglu, M., Lutz, R., Ergun, C., von Wilmowsky, C., Nkenke, E., and Schlegel, K. A. (2011). The effect of combined delivery of recombinant human bone morphogenetic protein-2 and recombinant human vascular endothelial growth factor 165 from biomimetic calcium-phosphate-coated implants on osseointegration. Clin. Oral Implants Res. 22, 1433-1439. doi: 10.1111/j.16000501.2010.02133.x

Ramazanoglu, M., Lutz, R., Rusche, P., Trabzon, L., Kose, G. T., Prechtl, C., et al. (2013). Bone response to biomimetic implants delivering BMP-2 and VEGF: an immunohistochemical study. Journal of cranio-maxillo-facial surgery: official 
publication of the European Association for Cranio-Maxillo-Facial. Surgery 41, 826-835. doi: 10.1016/j.jcms.2013.01.037

Rani, V. D., Vinoth-Kumar, L., Anitha, V., Manzoor, K., Deepthy, M., and Shantikumar, V. N. (2012). Osteointegration of titanium implant is sensitive to specific nanostructure morphology. Acta Biomater. 8, 1976-1989. doi: 10.1016/ j.actbio.2012.01.021

Rasmusson, L., Kahnberg, K. E., and Tan, A. (2001). Effects of implant design and surface on bone regeneration and implant stability: an experimental study in the dog mandible. Clin. Implant. Dent. Relat. Res. 3, 2-8. doi: 10.1111/j.17088208.2001.tb00123.x

Rasmusson, L., Roos, J., and Bystedt, H. (2005). A 10-year follow-up study of titanium dioxide-blasted implants. Clin. Implant. Dent. Relat. Res. 7, 36-42. doi: 10.1111/j.1708-8208.2005.tb00045.x

Ratier, A., Gibson, I. R., Best, S., Freche, M., Lacout, J., and Rodriguez, F. (2001). Setting characteristics and mechanical behaviour of a calcium phosphate bone cement containing tetracycline. Biomaterials 22, 897-901. doi: 10.1016/s01429612(00)00252-0

Ripamonti, U., Yeates, L., and Vandenheever, B. (1993). Initiation of heterotopic osteogenesis in primates after chromatographic adsorption of osteogenin, a bone morphogenetic protein, onto porous hydroxyapatite. Biochem. Biophys. Res. Commun. 193, 509-517. doi: 10.1006/bbrc.1993.1653

Rocci, A., Rocci, M., Rocci, C., Scoccia, A., Gargari, M., Martignoni, M., et al. (2013). Immediate loading of Brånemark system TiUnite and machined-surface implants in the posterior mandible, part II: a randomized open-ended 9-year follow-up clinical trial. Int. J. Oral Maxillofac. Implants 28, 891-895. doi: 10.11607/jomi.2397

Rodriguez y Baena, R., Arciola, C. R., Selan, L., Battaglia, R., Imbriani, M., Rizzo, S., et al. (2012). Evaluation of bacterial adhesion on machined titanium, Osseotite(R) and Nanotite(R) discs. Int. J. Artif. Organs 35, 754-761. doi: 10. 5301/ijao.5000143

Rønold, H., Lyngstadaas, S., and Ellingsen, J. (2003). Analysing the optimal value for titanium implant roughness in bone attachment using a tensile test. Biomaterials 24, 4559-4564. doi: 10.1016/s0142-9612(03)00256-4

Rotenberg, S. A., Steiner, R., and Tatakis, D. N. (2016). Collagen-coated bovine bone in peri-implantitis defects: a pilot study on a novel approach. Int. J. Oral Maxillofac. Implants 31, 701-707. doi: 10.11607/jomi.4303

Roy, M., Balla, V. K., Bandyopadhyay, A., and Bose, S. (2011). Compositionally graded hydroxyapatite/tricalcium phosphate coating on $\mathrm{Ti}$ by laser and induction plasma. Acta Biomater. 7, 866-873. doi: 10.1016/j.actbio.2010.09.016

Ruoslahti, E., and Pierschbacher, M. D. (1987). New perspectives in cell adhesion: RGD and integrins. Science 238, 491-497. doi: 10.1126/science.282 1619

Rupp, F., Gittens, R. A., Scheideler, L., Marmur, A., Boyan, B. D., Schwartz, Z., et al. (2014). A review on the wettability of dental implant surfaces I: theoretical and experimental aspects. Acta Biomater. 10, 2894-2906. doi: 10.1016/j.actbio.2014. 02.040

Rupp, F., Scheideler, L., Olshanska, N., de Wild, M., Wieland, M., and GeisGerstorfer, J. (2006). Enhancing surface free energy and hydrophilicity through chemical modification of microstructured titanium implant surfaces. J. Biomed. Mater. Res. A 76, 323-334. doi: 10.1002/jbm.a.30518

Rupp, F., Scheideler, L., Rehbein, D., Axmann, D., and Geis-Gerstorfer, J. (2004). Roughness induced dynamic changes of wettability of acid etched titanium implant modifications. Biomaterials 25, 1429-1438. doi: 10.1016/j.biomaterials. 2003.08.015

Ryan, G., Pandit, A., and Apatsidis, D. P. (2006). Fabrication methods of porous metals for use in orthopaedic applications. Biomaterials 27, 2651-2670. doi: 10.1016/j.biomaterials.2005.12.002

Sakou, T. (1998). Bone morphogenetic proteins: from basic studies to clinical approaches. Bone 22, 591-603. doi: 10.1016/s8756-3282(98)00053-2

Salerno, M., Itri, A., Frezzato, M., and Rebaudi, A. (2015). Surface microstructure of dental implants before and after insertion: An in vitro study by means of scanning probe microscopy. Implant Dent. 24, 248-255.

Samavedi, S., Horton, C. O., Guelcher, S. A., Goldstein, A. S., and Whittington, A. R. (2011). Fabrication of a model continuously graded co-electrospun mesh for regeneration of the ligament-bone interface. Acta Biomater. 7, 4131-4138. doi: 10.1016/j.actbio.2011.07.008

Sartoretto, S. C., Alves, A. T., Zarranz, L., Jorge, M. Z., Granjeiro, J. M., and Calasans-Maia, M. D. (2017). Hydrophilic surface of Ti6Al4V-ELI alloy improves the early bone apposition of sheep tibia. Clin. Oral Implants Res. 28, 893-901. doi: 10.1111/clr.12894

Sawase, T., Jimbo, R., Baba, K., Shibata, Y., Ikeda, T., and Atsuta, M. (2008). Photoinduced hydrophilicity enhances initial cell behavior and early bone apposition. Clin. Oral Implants Res. 19, 491-496. doi: 10.1111/j.1600-0501.2007.01509.x

Scarano, A., Crocetta, E., Quaranta, A., and Lorusso, F. (2018). Influence of the thermal treatment to address a better osseointegration of Ti6Al4V dental implants: histological and histomorphometrical study in a rabbit model. Biomed. Res. Int. 2018:2349698. doi: 10.1155/2018/2349698

Scarano, A., Lorusso, F., Orsini, T., Morra, M., Iviglia, G., and Valbonetti, L. (2019). Biomimetic surfaces coated with covalently immobilized collagen Type I: an $\mathrm{X}$-Ray photoelectron spectroscopy, atomic force microscopy, micro-CT and histomorphometrical study in rabbits. Int. J. Mol. Sci. 20:724. doi: 10.3390/ ijms 20030724

Scarano, A., Lorusso, F., Staiti, G., Sinjari, B., Tampieri, A., and Mortellaro, C. (2017a). Sinus augmentation with biomimetic nanostructured matrix: tomographic, radiological, histological and histomorphometrical results after 6 months in humans. Front. Physiol. 8:565. doi: 10.3389/fphys.2017.00565

Scarano, A., Piattelli, A., Quaranta, A., and Lorusso, F. (2017b). Bone response to two dental implants with different sandblasted/acid-etched implant surfaces: A histological and histomorphometrical study in rabbits. Biomed. Res. Int. 2017:8724951. doi: 10.1155/2017/8724951

Scarano, A., Perrotti, V., Artese, L., Degidi, M., Degidi, D., Piattelli, A., et al. (2014). Blood vessels are concentrated within the implant surface concavities: a histologic study in rabbit tibia. Odontology 102, 259-266. doi: 10.1007/s10266013-0116- 113

Schiefer, H., Bram, M., Buchkremer, H., and Stöver, D. (2009). Mechanical examinations on dental implants with porous titanium coating. J. Mater. Sci. Mater. Med. 20, 1763-1770. doi: 10.1007/s10856-009-3733-1

Schliephake, H., Rublack, J., Förster, A., Schwenzer, B., Reichert, J., and Scharnweber, D. (2015). Functionalization of titanium implants using a modular system for binding and release of VEGF enhances bone-implant contact in a rodent model. J. Clin. Periodontol. 42, 302-310. doi: 10.1111/jcpe. 12370

Schliephake, H., Scharnweber, D., Roesseler, S., Dard, M., Sewing, A., and Aref, A. (2006). Biomimetic calcium phosphate composite coating of dental implants. Int. J. Oral Maxillofac. Implants 21, 738-746.

Schmutz, P., Quach-Vu, N. C., and Gerber, I. (2008). Metallic medical implants: electrochemical characterization of corrosion processes. Electrochem. Soc. Interf. 17:35.

Schouten, C., Meijer, G., Van den Beucken, J., Spauwen, P., and Jansen, J. (2009). Effects of implant geometry, surface properties, and TGF- $\beta 1$ on peri-implant bone response: an experimental study in goats. Clin. Oral Implants Res. 20, 421-429. doi: 10.1111/j.1600-0501.2008.01657.x

Schwarz, F., Ferrari, D., Herten, M., Mihatovic, I., Wieland, M., Sager, M., et al. (2007a). Effects of surface hydrophilicity and microtopography on early stages of soft and hard tissue integration at non-submerged titanium implants: an immunohistochemical study in dogs. J. Periodontol. 78, 2171-2184. doi: 10. 1902/jop.2007.070157

Schwarz, F., Herten, M., Sager, M., Wieland, M., Dard, M., and Becker, J. (2007b). Histological and immunohistochemical analysis of initial and early osseous integration at chemically modified and conventional SLA ${ }^{\circledR}$ titanium implants: preliminary results of a pilot study in dogs. Clin. Oral Implants Res. 18, 481-488. doi: 10.1111/j.1600-0501.2007.01341.x

Senan, E., and Madfa, A. (2017). Functional Biomimetic Dental Restoration. London: IntechOpen

Shadanbaz, S., and Dias, G. J. (2012). Calcium phosphate coatings on magnesium alloys for biomedical applications: a review. Acta Biomater. 8, 20-30. doi: 10 . 1016/j.actbio.2011.10.016

Shalabi, M., Gortemaker, A., Hof, M. V. T., Jansen, J., and Creugers, N. (2006). Implant surface roughness and bone healing: a systematic review. J. Dent. Res. 85, 496-500. doi: 10.1177/154405910608500603

Sharifi, E., Azami, M., Kajbafzadeh, A. M., Moztarzadeh, F., Faridi-Majidi, R., Shamousi, A., et al. (2016). Preparation of a biomimetic composite scaffold from gelatin/collagen and bioactive glass fibers for bone Tissue Eng. Mater. Sci. .Eng C 59, 533-541. doi: 10.1016/j.msec.2015.09.037

Shayganpour, A., Rebaudi, A., Cortella, P., Diaspro, A., and Salerno, M. (2015). Electrochemical coating of dental implants with anodic porous titania for 
enhanced osteointegration. Beilstein J. Nanotechnol. 6, 2183-2192. doi: 10.3762/ bjnano.6.224

Shen, X., Ma, P., Hu, Y., Xu, G., Zhou, J., and Cai, K. (2015). Mesenchymal stem cell growth behavior on micro/nano hierarchical surfaces of titanium substrates. Colloids Surf. B Biointerf. 127, 221-232. doi: 10.1016/j.colsurfb.2015.01.048

Shibata, Y., and Tanimoto, Y. (2015). A review of improved fixation methods for dental implants. Part I: Surface optimization for rapid osseointegration. J. Prosthodont. Res. 59, 20-33. doi: 10.1016/j.jpor.2014.11.007

Shokuhfar, T., Hamlekhan, A., Chang, J. Y., Choi, C. K., Sukotjo, C., and Friedrich, C. (2014). Biophysical evaluation of cells on nanotubular surfaces: the effects of atomic ordering and chemistry. Int. J. Nanomed. 9, 3737-3748. doi: 10.2147/ijn. s67344

Shrestha, S. (2014). Current concepts in biomaterials in dental implant. Sci. Res. 2, $7-12$.

Sidambe, A. T. (2014). Biocompatibility of advanced manufactured Titanium implants-a review. Materials 7, 8168-8188. doi: 10.3390/ma7128168

Simmons, C. A., Valiquette, N., and Pilliar, R. M. (1999). Osseointegration of sintered porous-surfaced and plasma spray-coated implants: An animal model study of early postimplantation healing response and mechanical stability. J. Biomed. Mater. Res. 47, 127-138. doi: 10.1002/(sici)1097-4636(199911)47: $2<127:$ :aid-jbm3 $>3.0 . c 0 ; 2-c$

Sinjari, B., Traini, T., Caputi, S., Mortellaro, C., and Scarano, A. (2018). Evaluation of Fibrin clot attachment on Titanium laser-conditioned surface using scanning electron microscopy. J. Craniofac. Surg. 29, 2277-2281. doi: 10.1097/scs. 0000000000004519

Sioshansi, P. (1987). Surface modification of industrial components by ion implantation. Mater. Sci. Eng. 90, 373-383. doi: 10.1016/0025-5416(87)9023590237

Sivakumar, M., Manjubala, I., and Rao, K. P. (2002). Preparation, characterization and in-vitro release of gentamicin from coralline hydroxyapatite-chitosan composite microspheres. Carbohydr. Polym. 49, 281-288. doi: 10.1016/s0144$8617(01) 00331-9$

Sivakumar, M., and Rao, K. P. (2002). Preparation, characterization and in vitro release of gentamicin from coralline hydroxyapatite-gelatin composite microspheres. Biomaterials 23, 3175-3181. doi: 10.1016/s0142-9612(02) 00066-2

Smeets, R., Stadlinger, B., Schwarz, F., Beck-Broichsitter, B., Jung, O., Precht, C., et al. (2016). Impact of dental implant surface modifications on osseointegration. Biomed. Res. Int. 2016:6285620. doi: 10.1155/2016/6285620

Smith, B. S., Yoriya, S., Johnson, T., and Popat, K. C. (2011). Dermal fibroblast and epidermal keratinocyte functionality on titania nanotube arrays. Acta Biomater. 7, 2686-2696. doi: 10.1016/j.actbio.2011.03.014

Smith, D. C. (1993). Dental implants: materials and design considerations. Int. J. Prosthodont. 6, 106-117.

Stadlinger, B., Bierbaum, S., Grimmer, S., Schulz, M. C., Kuhlisch, E., Scharnweber, D., et al. (2009). Increased bone formation around coated implants. J. Clin. Periodontol. 36, 698-704. doi: 10.1111/j.1600-051X.2009.01435.x

Stadlinger, B., Hintze, V., Bierbaum, S., Moller, S., Schulz, M. C., Mai, R., et al. (2012). Biological functionalization of dental implants with collagen and glycosaminoglycans-A comparative study. J. Biomed. Mater. Res. B 100, 331-341. doi: 10.1002/jbm.b.31953

Stadlinger, B., Pilling, E., Huhle, M., Mai, R., Bierbaum, S., Bernhardt, R., et al. (2007). Influence of extracellular matrix coatings on implant stability and osseointegration: an animal study. J. Biomed. Mater. Res. B 83, 222-231. doi: 10.1002/jbm.b.30787

Stadlinger, B., Pilling, E., Huhle, M., Mai, R., Bierbaum, S., Scharnweber, D., et al. (2008a). Evaluation of osseointegration of dental implants coated with collagen, chondroitin sulphate and BMP-4: an animal study. Int. J. Oral Maxillofac. Surg. 37, 54-59. doi: 10.1016/j.ijom.2007.05.024

Stadlinger, B., Pilling, E., Mai, R., Bierbaum, S., Berhardt, R., Scharnweber, D., et al. (2008b). Effect of biological implant surface coatings on bone formation, applying collagen, proteoglycans, glycosaminoglycans and growth factors. J. Mater. Sci. Mater. Med. 19, 1043-1049. doi: 10.1007/s10856-007-3077-3077

Stevens, M. M., and George, J. H. (2005). Exploring and engineering the cell surface interface. Science 310, 1135-1138. doi: 10.1126/science.1106587

Stigter, M., Bezemer, J., De Groot, K., and Layrolle, P. (2004). Incorporation of different antibiotics into carbonated hydroxyapatite coatings on titanium implants, release and antibiotic efficacy. J. Control Rel. 99, 127-137. doi: 10. 1016/j.jconrel.2004.06.011
Stigter, M., De Groot, K., and Layrolle, P. (2002). Incorporation of tobramycin into biomimetic hydroxyapatite coating on titanium. Biomaterials 23, 4143-4153. doi: 10.1016/s0142-9612(02)00157-6

Streckbein, P., Kleis, W., Buch, R. S., Hansen, T., and Weibrich, G. (2014). Bone healing with or without platelet-rich plasma around four different dental implant surfaces in beagle dogs. Clin. Implant. Dent. Relat. Res. 16, 479-486. doi: $10.1111 /$ cid.12026

Sul, Y. T., Byon, E., and Wennerberg, A. (2008). Surface characteristics of electrochemically oxidized implants and acid-etched implants: surface chemistry, morphology, pore configurations, oxide thickness, crystal structure, and roughness. Int. J. Oral Maxillofac. Implants 23, 631-640.

Sul, Y. T., Johansson, C. B., Roser, K., and Albrektsson, T. (2002). Qualitative and quantitative observations of bone tissue reactions to anodised implants. Biomaterials 23, 1809-1817. doi: 10.1016/s0142-9612(01)00307-6

Sun, P., Wang, J., Zheng, Y., Fan, Y., and Gu, Z. (2012). BMP2/7 heterodimer is a stronger inducer of bone regeneration in peri-implant bone defects model than BMP2 or BMP7 homodimer. Dent. Mater. J. 31, 239-248. doi: 10.4012/dmj. 2011-191

Sykaras, N., Iacopino, A. M., Marker, V. A., Triplett, R. G., and Woody, R. D. (2000). Implant materials, designs, and surface topographies: their effect on osseointegration. A literature review. Int. J. Oral Maxillofac. Implants 15, 675-690.

Tadic, D., Welzel, T., Seidel, P., Wüst, E., Dingeldein, E., and Epple, M. (2004). Controlled release of gentamicin from biomimetic calcium phosphate in vitro. Comparison of four different incorporation methods. Materialwissenschaft Werkstofftechnik 35, 1001-1005. doi: 10.1002/mawe.200400841

Takahashi, H. (1993). Mechanical properties of functional gradient materials of titanium-apatite and titanium zirconia for dental use. J. Jpn. Soc. Dent. Mater. Devices 12, 595-612.

Takechi, M., Miyamoto, Y., Ishikawa, K., Nagayama, M., Kon, M., Asaoka, K., et al. (1998). Effects of added antibiotics on the basic properties of anti-washout-type fast-setting calcium phosphate cement. J. Biomed. Mater. Res. A 39, 308-316. doi: 10.1002/(sici)1097-4636(199802)39:2<308::aid-jbm19>3.0.co;2-8

Tan, A., Pingguan-Murphy, B., Ahmad, R., and Akbar, S. (2012). Review of titania nanotubes: fabrication and cellular response. Ceram. Int. 38, 4421-4435. doi: 10.1016/j.ceramint.2012.03.002

Tan, A. W., Pingguan-Murphy, B., Ahmad, R., and Akbar, S. A. (2013). Advances in fabrication of $\mathrm{TiO} 2$ nanofiber/nanowire arrays toward the cellular response in biomedical implantations: A review. J. Mater. Sci. 48, 8337-8353. doi: 10.1007/ s10853-013-7659-0

Tavangar, A., Tan, B., and Venkatakrishnan, K. (2011). Synthesis of bio-functionalized three-dimensional titania nanofibrous structures using femtosecond laser ablation. Acta Biomater. 7, 2726-2732. doi: 10.1016/j.actbio.2011.02.020

Teixeira, L., Crippa, G., Lefebvre, L.-P., De Oliveira, P., Rosa, A., and Beloti, M. (2012). The influence of pore size on osteoblast phenotype expression in cultures grown on porous titanium. Int. J. Oral Maxillofac. Surg. 41, 1097-1101. doi: 10.1016/j.ijom.2012.02.020

Tinsley, D., Watson, C. J., and Russell, J. L. (2001). A comparison of hydroxylapatite coated implant retained fixed and removable mandibular prostheses over 4 to 6 years. Clin. Oral Implants Res. 12, 159-166. doi: 10.1034/j.1600-0501.2001. 012002159.x

Tolochko, N., Savich, V., Laoui, T., Froyen, L., Onofrio, G., Signorelli, E., et al. (2002). Dental root implants produced by the combined selective laser sintering/melting of titanium powders. Proc. Inst. Mech. Eng. Pt L J Mater. Des Appl. 216, 267-270. doi: 10.1177/146442070221600406

Tomisa, A. P., Launey, M. E., Lee, J. S., Mankani, M. H., Wegst, U. G. K., and Saiz, E. (2011). Nanotechnology approaches to improve dental implants. Int. J. Oral Maxillofac. Implants 26, 25-49.

Traini, T., Mangano, C., Sammons, R., Mangano, F., Macchi, A., and Piattelli, A. (2008). Direct laser metal sintering as a new approach to fabrication of an isoelastic functionally graded material for manufacture of porous titanium dental implants. Dent. Mater. 24, 1525-1533. doi: 10.1016/j.dental.2008.03.029

Truong, V. K., Lapovok, R., Estrin, Y. S., Rundell, S., Wang, J. Y., Fluke, C. J., et al. (2010). The influence of nano-scale surface roughness on bacterial adhesion to ultrafine-grained titanium. Biomaterials 31, 3674-3683. doi: 10 . 1016/j.biomaterials.2010.01.071

Tsimbouri, P. M., Fisher, L., Holloway, N., Sjostrom, T., Nobbs, A. H., Meek, R. M., et al. (2016). Osteogenic and bactericidal surfaces from hydrothermal 
titania nanowires on titanium substrates. Sci. Rep. 6:36857. doi: 10.1038/srep 36857

Tsui, Y. C., Doyle, C., and Clyne, T. W. (1998a). Plasma sprayed hydroxyapatite coatings on titanium substrates. Part 1: Mechanical properties and residual stress levels. Biomaterials 19, 2015-2029. doi: 10.1016/s0142-9612(98) 00103-3

Tsui, Y. C., Doyle, C., and Clyne, T. W. (1998b). Plasma sprayed hydroxyapatite coatings on titanium substrates. Part 2: optimisation of coating properties. Biomaterials 1998, 2031-2043. doi: 10.1016/s0142-9612(98)00104-5

Tugulu, S., Löwe, K., Scharnweber, D., and Schlottig, F. (2010). Preparation of superhydrophilic microrough titanium implant surfaces by alkali treatment. J. Mater. Sci. Mater. Med. 21, 2751-2763. doi: 10.1007/s10856-010-4138-x

Urban, R. M., Jacobs, J. J., Tomlinson, M. J., Gavrilovic, J., Black, J., and Peoc'h, M. (2000). Dissemination of wear particles to the liver, spleen, and abdominal lymph nodes of patients with hip or knee replacement. J. Bone Joint Surg. Am. $82,457-476$

Urist, M. R. (1965). Bone: formation by autoinduction. Science 150, 893-899. doi: $10.1126 /$ science. 150.3698 .893

van de Belt, H., Neut, D., Schenk, W., van Horn, J. R., van der Mei, H. C., and Busscher, H. J. (2001). Infection of orthopedic implants and the use of antibiotic-loaded bone cements: a review. Acta Orthop. Scand. 72, 557-571. doi: 10.1080/000164701317268978

van Drunen, J., Zhao, B., and Jerkiewicz, G. (2011). Corrosion behavior of surfacemodified titanium in a simulated body fluid. J. Mater. Sci. 46, 5931-5939. doi: 10.1007/s10853-011-5548-y

van Grunsven, W., Hernandez-Nava, E., Reilly, G. C., and Goodall, R. (2014). Fabrication and mechanical characterisation of titanium lattices with graded porosity. Metals 4, 401-409. doi: 10.3390/met4030401

Van Noort, R. (2014). Introduction to Dental Materials-E-Book. Amsterdam: Elsevier Health Sciences.

van Steenberghe, D., De Mars, G., Quirynen, M., Jacobs, R., and Naert, I. (2000). A prospective split-mouth comparative study of two screw-shaped self-tapping pure titanium implant systems. Clin. Oral Implants Res. 11, 202-209. doi: 10. 1034/j.1600-0501.2000.011003202.x

Vaz, L., Lopes, A., and Almeida, M. (1999). Porosity control of hydroxyapatite implants. J. Mater. Sci. Mater. Med. 10, 239-242.

von Wilmowsky, C., Moest, T., Nkenke, E., Stelzle, F., and Schlegel, K. A. (2014). Implants in bone: Part II. Research on implant osseointegration. Oral Maxillofac. Surg. 18, 355-372.

Walter, M., Frank, M., Satue, M., Monjo, M., Rønold, H., Lyngstadaas, S., et al. (2014). Bioactive implant surface with electrochemically bound doxycycline promotes bone formation markers in vitro and in vivo. Dent. Mater. 30, 200-214. doi: 10.1016/j.dental.2013.11.006

Wang, F., Lee, H., and Lu, C. (2007). Thermal-mechanical study of functionally graded dental implants with the finite element method. J. Biomed. Mater. Res. A 80, 146-158. doi: 10.1002/jbm.a.30855

Wang, J., de Boer, J., and De Groot, K. (2004). Preparation and characterization of electrodeposited calcium phosphate/chitosan coating on Ti6Al4V plates. J. Dent. Res. 83, 296-301. doi: 10.1177/154405910408300405

Wang, M., Yang, X., Khor, K., and Wang, Y. (1999). Preparation and characterization of bioactive monolayer and functionally graded coatings. J. Mater. Sci. Mater. Med. 10, 269-273.

Wang, X., Zhu, J., Yin, L., Liu, S., Zhang, X., Ao, Y., et al. (2012). Evaluation of the morphology and osteogenic potential of titania-based electrospun nanofibers. J. Nanomater. 2012:20.

Wang, X.-X., Yan, W., Hayakawa, S., Tsuru, K., and Osaka, A. (2003). Apatite deposition on thermally and anodically oxidized titanium surfaces in a simulated body fluid. Biomaterials 24, 4631-4637. doi: 10.1016/s0142-9612(03) 00357-0

Wang, Z., Dong, L., Han, L., Wang, K., Lu, X., Fang, L., et al. (2016). Selfassembled biodegradable nanoparticles and polysaccharides as biomimetic ECM Nanostructures for the Synergistic effect of RGD and BMP-2 on bone formation. Sci. Rep. 6:25090. doi: 10.1038/srep25090

Watari, F., Yokoyama, A., Omori, M., Hirai, T., Kondo, H., Uo, M., et al. (2004). Biocompatibility of materials and development to functionally graded implant for bio-medical application. Compos. Sci. Technol. 64, 893-908. doi: 10.1016/j. compscitech.2003.09.005

Waterman, J., Pietak, A., Birbilis, N., Woodfield, T., Dias, G., and Staiger, M. P. (2011). Corrosion resistance of biomimetic calcium phosphate coatings on magnesium due to varying pretreatment time. Mater. Sci. Eng. B 176, 17561760. doi: 10.1016/j.mseb.2011.06.021

Webster, T., and Yao, C. (2016). "Anodization: a promising nano modification technique of titanium-based implants for orthopedic applications," in Surgical Tools and Medical Devices, eds W. Ahmed, and M. J. Jackson (Berlin: Springer), 55-79. doi: 10.1007/978-3-319-33489-9_2

Wei, G., and Ma, P. (2008). Nanostructured biomaterials for regeneration. $A d v$. Funct. Mater. 18, 3566-3582.

Wen, H., De Wijn, J., Van Blitterswijk, C., and De Groot, K. (1999). Incorporation of bovine serum albumin in calcium phosphate coating on titanium. J. Biomed. Mater. Res. A 46, 245-252. doi: 10.1002/(sici)1097-4636(199908)46:2<245:: aid-jbm14>3.0.co;2-a

Wennerberg, A., and Albrektsson, T. (2009). Effects of titanium surface topography on bone integration: a systematic review. Clin. Oral Implants Res. 20, 172-184. doi: 10.1111/j.1600-0501.2009.01775.x

Wennerberg, A., and Albrektsson, T. (2010). On implant surfaces: a review of current knowledge and opinions. Int. J. Oral Maxillofac. Implants 25, 63-74.

Wennerberg, A., Galli, S., and Albrektsson, T. (2011). Current knowledge about the hydrophilic and nanostructured SLActive surface. Clin. Cosmetic Invest. Dent. 3:59. doi: 10.2147/cciden.s15949

Wennerberg, A., Jimbo, R., and Albrektsson, T. (2015). Implant Surfaces and Their Biological and Clinical Impact. Berlin: Springer, 1-182. doi: 10.1007/978-3-66245379-7

Werner, J., Linner-Krèmar, B., Friess, W., and Greil, P. (2002). Mechanical properties and in vitro cell compatibility of hydroxyapatite ceramics with graded pore structure. Biomaterials 23, 4285-4294. doi: 10.1016/s01429612(02)00191-6

Wheeler, S. L. (1996). Eight-year clinical retrospective study of titanium plasmasprayed and hydroxyapatite-coated cylinder implants. Int. J. Oral Maxillofac. Implants 11, 340-350.

Wikesjö, U. M., Huang, Y. H., Xiropaidis, A. V., Sorensen, R. G., Rohrer, M. D., Prasad, H. S., et al. (2008a). Bone formation at recombinant human bone morphogenetic protein-2-coated titanium implants in the posterior maxilla (Type IV bone) in non-human primates. J. Clin. Periodontol. 35, 992-1000. doi: 10.1111/j.1600-051X.2008.01322.X

Wikesjö, U. M., Xiropaidis, A. V., Qahash, M., Lim, W. H., Sorensen, R. G., Rohrer, M. D., et al. (2008b). Bone formation at recombinant human bone morphogenetic protein-2-coated titanium implants in the posterior mandible (Type II bone) in dogs. J. Clin. Periodontol. 35, 985-991. doi: 10.1111/j.1600051X.2008.01318.x

Williams, D. (1987). "Progress in biomedical engineering, definitions in biomaterials," in Proceedings of a Consensus Conference of the European Society for Materials (Amsterdam: Elsevier).

Wilson-Hench, J. (1987). “Osteoinduction," in Progress in biomedical engineering, Definitions in biomaterials, ed. D. F. Williams (Amsterdam: Elsevier).

Wirth, J., Tahriri, M., Khoshroo, K., Rasoulianboroujeni, M., Dentino, A. R., and Tayebi, L. (2017). "6 - Surface modification of dental implants," in Biomaterials for Oral and Dental Tissue Eng, eds L. Tayebi and K. Moharamzadeh (Sawston: Woodhead Publishing), 85-96. doi: 10.1016/B978-0-08-100961-1.00006-2pp

Witek, L., Marin, C., Granato, R., Bonfante, E. A., Campos, F., Bisinotto, J., et al. (2012). Characterization and in vivo evaluation of laser sintered dental endosseous implants in dogs. J. Biomed. Mater. Res. B 100, 1566-1573. doi: 10.1002/jbm.b.32725

Wolinsky, L. E., de Camargo, P. M., Erard, J. C., and Newman, M. G. (1989). A study of in vitro attachment of Streptococcus sanguis and Actinomyces viscosus to saliva-treated titanium. Int. J. Oral Maxillofac. Implants 4, 27-31.

Wolke, J., De Groot, K., and Jansen, J. (1998a). In vivo dissolution behavior of various RF magnetron sputtered Ca-P coatings. J. Biomed. Mater. Res. A 39, 524-530. doi: 10.1002/jbm.a.35173

Wolke, J., De Groot, K., and Jansen, J. (1998b). Subperiosteal implantation of various RF magnetron sputtered Ca-P coatings in goats. J. Biomed. Mater. Res. 43, 270-276. doi: 10.1002/(sici)1097-4636(199823)43:3<270::aid-jbm7>3.0. co;2-k

Wolke, J., Van Dijk, K., Schaeken, H., De Groot, K., and Jansen, J. (1994). Study of the surface characteristics of magnetron-sputter calcium phosphate coatings. J. Biomed. Mater. Res. 28, 1477-1484. doi: 10.1002/jbm.820281213

Wong, M., Eulenberger, J., Schenk, R., and Hunziker, E. (1995). Effect of surface topology on the osseointegration of implant materials in trabecular bone. J. Biomed. Mater. Res. 29, 1567-1575. doi: 10.1002/jbm.820291213 
Xiao, M., Biao, M., Chen, Y., Xie, M., and Yang, B. (2016). Regulating the osteogenic function of rhBMP 2 by different titanium surface properties. J. Biomed. Mater. Res. A 104, 1882-1893. doi: 10.1002/jbm.a.35719

Xie, C., Lu, X., and Wang, K. (2015). Pulse electrochemical synthesis of spherical hydroxyapatite and silver nanoparticles mediated by the polymerization of polypyrrole on metallic implants for biomedical applications. Part Part Syst. Charact. 32, 630-635. doi: 10.1002/ppsc.201400245

Xie, Y., Zheng, X., Huang, L., and Ding, C. (2012). Influence of hierarchical hybrid micro/nano-structured surface on biological performance of titanium coating. J. Mater. Sci. 47, 1411-1417. doi: 10.1007/s10853-011-5921-x

Xing, H., Wang, X., Xiao, S., Zhang, G., Li, M., Wang, P., Shi, Q., et al. (2017). Osseointegration of layer-by-layer polyelectrolyte multilayers loaded with IGF1 and coated on titanium implant under osteoporotic condition. Int. J. Nanomed. 12:7709. doi: 10.2147/IJN.S148001

Xing, R., Witsø, I. L., Jugowiec, D., Tiainen, H., Shabestari, M., Lyngstadaas, S. P., et al. (2015). Antibacterial effect of doxycycline-coated dental abutment surfaces. Biomed. Mater. 10:055003. doi: 10.1088/1748-6041/10/5/055003

Yamada, K., Imamura, K., Itoh, H., Iwata, H., and Maruno, S. (2001). Bone bonding behavior of the hydroxyapatite containing glass-titanium composite prepared by the Cullet method. Biomaterials 22, 2207-2214. doi: 10.1016/s0142-9612(00) 00402-6

Yan, Y., Zhang, X., Huang, Y., Ding, Q., and Pang, X. (2014). Antibacterial and bioactivity of silver substituted hydroxyapatite/TiO2 nanotube composite coatings on titanium. Appl. Surf. Sci. 314, 348-357. doi: 10.1016/j.apsusc.2014. 07.027

Yan, Y., Zhang, X., Li, C., Huang, Y., Ding, Q., and Pang, X. (2015). Preparation and characterization of chitosan-silver/hydroxyapatite composite coatings onTiO2 nanotube for biomedical applications. Appl. Surf. Sci. 332, 62-69. doi: 10.1016/ j.apsusc.2015.01.136

Yang, B., Uchida, M., Kim, H.-M., Zhang, X., and Kokubo, T. (2004). Preparation of bioactive titanium metal via anodic oxidation treatment. Biomaterials 25, 1003-1010. doi: 10.1016/s0142-9612(03)00626-4

Yang, G. L., He, F. M., Yang, X. F., Wang, X. X., and Zhao, S. F. (2009). In vivo evaluation of bone-bonding ability of RGD-coated porous implant using layerby-layer electrostatic self-assembly. J. Biomed. Mater. Res. A 90, 175-185. doi: 10.1002/jbm.a.32055

Yang, J., and Xiang, H. J. (2007). A three-dimensional finite element study on the biomechanical behavior of an FGBM dental implant in surrounding bone. J. Biomech. 40, 2377-2385. doi: 10.1016/j.jbiomech.2006.11.019

Yazici, H., O’Neill, M. B., Kacar, T., Wilson, B. R., Oren, E. E., Sarikaya, M., et al. (2016). Engineered chimeric peptides as antimicrobial surface coating agents toward infection-free implants. ACS Appl. Mater. Interf. 8, 5070-5081. doi: $10.1021 /$ acsami.5b03697

Yeo, I. S. (2014). Reality of dental implant surface modification: a short literature review. Open Biomed. Eng. J. 8:114. doi: 10.2174/1874120701408010114

Yin, K., Wang, Z., Fan, X., Bian, Y., Guo, J., and Lan, J. (2012). The experimental research on two-generation BLB dental implants-Part I: surface modification and osseointegration. Clin. Oral Implants Res. 23, 846-852. doi: 10.1111/j.16000501.2011.02209.x

Yoo, S. Y., Kim, S. K., Heo, S. J., Koak, J. Y., Lee, J. H., and Heo, J. M. (2015) Biochemical responses of anodized Titanium implants with a poly(lactide-coglycolide)/bone Morphogenetic Protein-2 Submicron Particle Coating. Part 2: an in vivo study. Int. J. Oral Maxillofac. Implants 30, 754-760. doi: 10.11607/ jomi.3701b

Yucesoy, D. T., Hnilova, M., Boone, K., Arnold, P. M., Snead, M. L., and Tamerler, C. (2015). Chimeric peptides as implant functionalization agents for titanium alloy implants with antimicrobial properties. JOM 67, 754-766. doi: 10.1007/ s11837-015-1350-7

Zarone, F., Apicella, D., Sorrentino, R., Ferro, V., Aversa, R., and Apicella, A. (2005). Influence of tooth preparation design on the stress distribution in maxillary central incisors restored by means of alumina porcelain veneers: a
3D-finite element analysis. Dent. Mater. 21, 1178-1188. doi: 10.1016/j.dental. 2005.02.014

Zarone, F., Sorrentino, R., Apicella, D., Valentino, B., Ferrari, M., Aversa, R., et al. (2006). Evaluation of the biomechanical behavior of maxillary central incisors restored by means of endocrowns compared to a natural tooth: a 3D static linear finite elements analysis. Dent. Mater. 22, 1035-1044. doi: 10.1016/j.dental.2005. 11.034

Zechner, W., Tangl, S., Fürst, G., Tepper, G., Thams, U., Mailath, G., et al. (2003). Osseous healing characteristics of three different implant types: A histologic and histomorphometric study in mini-pigs. Clin. Oral Implants Res. 14, 150-157. doi: 10.1034/j.1600-0501.2003.140203.x

Zhang, M., and Kataoka, K. (2009). Nano-structured composites based on calcium phosphate for cellular delivery of therapeutic and diagnostic agents. Nano Today 4, 508-517. doi: 10.1016/j.nantod.2009.10.009

Zhang, Q., Leng, Y., and Xin, R. (2005). A comparative study of electrochemical deposition and biomimetic deposition of calcium phosphate on porous titanium. Biomaterials 26, 2857-2865. doi: 10.1016/j.biomaterials.2004. 08.016

Zhang, W., Li, Z., Huang, Q., Xu, L., Li, J., Jin, Y., et al. (2013a). Effects of a hybrid micro/nanorod topography-modified titanium implant on adhesion and osteogenic differentiation in rat bone marrow mesenchymal stem cells. Int. J. Nanomed. 8, 257-265. doi: 10.2147/ijn.s39357

Zhang, W., Wang, G., Liu, Y., Zhao, X., Zou, D., Zhu, C., et al. (2013b). The synergistic effect of hierarchical micro/nano-topography and bioactive ions for enhanced osseointegration. Biomaterials 34, 3184-3195. doi: 10.1016/j. biomaterials.2013.01.008

Zhang, X., Geng, H., Gong, L., Zhang, Q., Li, H., Zhang, X., et al. (2018). Modification of the surface of titanium with multifunctional chimeric peptides to prevent biofilm formation via inhibition of initial colonizers. Int. J. Nanomed. 13:5361. doi: 10.2147/IJN.S170819

Zhang, Y., and Zhang, M. (2002). Calcium phosphate/chitosan composite scaffolds for controlled in vitro antibiotic drug release. J. Biomed. Mater. Res. A 62, 378-386. doi: 10.1002/jbm.10312

Zhao, F., Wang, J., Guo, H., Liu, S., and He, W. (2015). The effects of surface properties of nanostructured bone repair materials on their performances. J. Nanomater. 2015:1-11. doi: 10.1155/2015/893545

Zhao, L., Chu, P. K., Zhang, Y., and Wu, Z. (2009). Antibacterial coatings on titanium implants. J. Biomed. Mater. Res. B 91, 470-480.

Zhu, X., Chen, J., Scheideler, L., Altebaeumer, T., Geis-Gerstorfer, J., and Kern, D. (2004). Cellular reactions of osteoblasts to micron- and submicron-scale porous structures of titanium surfaces. Cells Tissues Organs 178, 13-22. doi: $10.1159 / 000081089$

Zinger, O., Anselme, K., Denzer, A., Habersetzer, P., Wieland, M., Jeanfils, J., et al. (2004). Time-dependent morphology and adhesion of osteoblastic cells on titanium model surfaces featuring scale-resolved topography. Biomaterials 25, 2695-2711. doi: 10.1016/j.biomaterials.2003.09.111

Zitzmann, N. U., and Berglundh, T. (2008). Definition and prevalence of periimplant diseases. J. Clin. Periodontol. 35, 286-291. doi: 10.1111/j.1600-051X. 2008.01274.x

Conflict of Interest: The authors declare that the research was conducted in the absence of any commercial or financial relationships that could be construed as a potential conflict of interest.

Copyright (c) 2020 Al-Zubaidi, Madfa, Mufadhal, Aldawla, Hameed and Yue. This is an open-access article distributed under the terms of the Creative Commons Attribution License (CC BY). The use, distribution or reproduction in other forums is permitted, provided the original author(s) and the copyright owner(s) are credited and that the original publication in this journal is cited, in accordance with accepted academic practice. No use, distribution or reproduction is permitted which does not comply with these terms. 